\title{
POVERTY AND COMMUNITARIANISM: TOWARD A COMMUNITY-BASED WELFARE SYSTEM
}

\author{
Michele Estrin Gilman ${ }^{*}$
}

Table of Contents

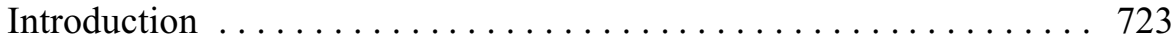

I. The Communitarian Response to Liberalism . . . . . . . . . . . . 729

A. The Liberalism of John Rawls . . . . . . . . . . . . . . . 729

B. The Communitarian Position ................ 733

C. The Communitarian Influence in Social Welfare . . . . . . 736

1. Reciprocity .......................... 737

2. Incentives to Change Behavior ............. 738

3. Mediating Institutions $\ldots \ldots \ldots \ldots \ldots \ldots \ldots \ldots$

4. Community Values and Communitarian Politics .... . . 740

D. An Assessment of TANF . . . . . . . . . . . . . . . . . . . . . . 741

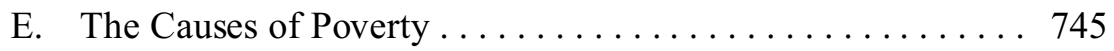

II. The Limits of Communitarianism $\ldots \ldots \ldots \ldots \ldots \ldots \ldots \ldots 750$

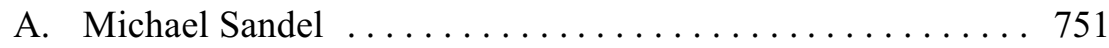

1. Sandel's Attack on the Procedural Republic ........ 752

a. The Supreme Court and the Procedural Republic .. 753

b. The Welfare State and the Rise of the Procedural

Republic ...................... 755

c. Repairing the Procedural Republic . . . . . . . . 756

2. A Critical Assessment of Sandel . . . . . . . . . . . . . . 757

a. Sandel's Communities and Poor Communities ... 757

b. Barriers to Public Participation in Poor

Communities ... . . . . . . . . . . . . . . . . . . . 759

c. The Dangers of Majoritarianism ......... 760

d. The Welfare State and Rights Discourse ....... 763

e. The Procedural Republic and the Poor ......... 764

\footnotetext{
* Associate Profes sor of Law and Director, Civil Advocacy Clinic, University of Baltimore School of Law. B.A. 1990, Duke University; J.D. 1993, University of Michigan Law School. I would like to thank Leigh Goodmark, Neil Gilman, Audrey McFarlane, Ngai Pindell, Robert Rubinson, Dana Shoenberg, Jim Kelly, and the participants in workshops at the AALS Conference on Clinical Legal Education and the MidAtlantic Clinical Theory Conference for their comments on drafts of this article.
} 
f. The Supreme Court and the Morals of the Poor . . . 765

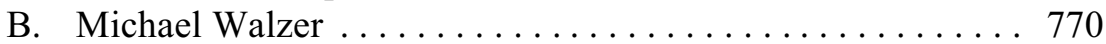

1. Complex Equality . . . . . . . . . . . . . . . . . . . . 770

2. A Critical Assessment of Complex Equality ... . . . . . 772

C. Amitai Etzioni and Communitarian Politics . . . . . . . . 778

1. Etzioni and a Return to Values ... . . . . . . . . . . . 778

2. A Critical Assessment of Etzioni .............. 781

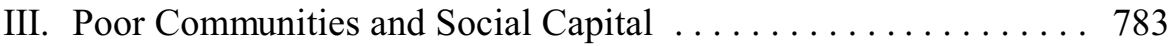

A. All Our Kin ......................... 785

B. Social Networks in the Face of Welfare Reform . . . . . . 787

C. Robert Taylor Homes and the Politics of Poverty ......... 788

D. Dudley Street Neighborhood Initiative and the Triumph of Community ............................. 790

E. Lessons Learned from Poor, Urban Communities . . . . . . 793

IV. A Community-Based Welfare System . . . . . . . . . . . . 795

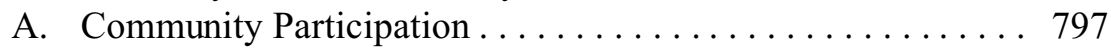

B. Barriers to Work ...................... 800

1. Child Care ...................... 801

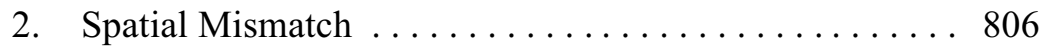

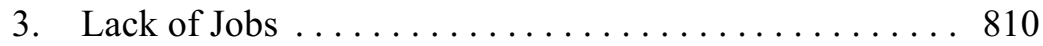

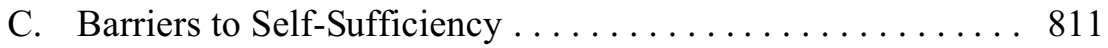

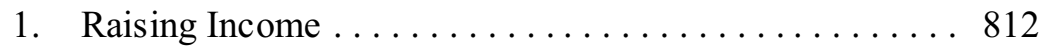

2. Educational Opportunity $\ldots \ldots \ldots \ldots \ldots \ldots \ldots . \ldots 814$

3. Asset Development ................... 816

D. Welfare and Morals ... . . . . . . . . . . . . . . . . 817

Conclusion ............................... 819 
This Article analyzes how communitarian political theory addresses povertyand impacts American social welfare programs. For several decades, communitarian and liberal philosophers have debated over how best to achieve justice through their competing notions of personhood. Whereas liberal theorists stress the values of individual autonomy and state neutrality, communitarians assert that people are socially constituted and that liberalism therefore pays too little attention to the value of community. Yet despite their attempts to articulate a superior form of justice, communitarian theorists either ignore or misunderstand issues related to poverty, as this Article explains. Nevertheless, their insights are helpful in thinking about combating inequity. Not only does communitarian theory support collective responsibility for alleviating economic injustice, but it also provides a framework for moving away from individual blame as an explanation for poverty. Current welfare law is based on the idea that individual behavior and choices cause poverty. As a result, welfare recipients are required to work without adequate social and economic supports to enable selfsufficiency, and most remain mired in poverty. By contrast, this Article describes an alternative, pragmatic vision for welfare that builds upon the social capital that exists within distressed urban communities as a way to improve individual outcomes.

\section{INTRODUCTION}

In recent years, liberal and communitarian political theorists have battled over whether justice is best achieved through individual autonomy or through collective values. While liberals believe that human dignity is fostered when people select their own ends, communitarians counter that autonomy is a myth given the communal connections that encumber us and make us who we are. These heated intellectual debates have spilled beyond the walls of academia and seeped into the political arena, as communitarians have sought to claim a middle-ground between the political right and left and to temper rights-based rhetoric by offering an alternative based on shared moral values and joint responsibilities. A small, but vocal, political movement of communitarians has published a platform to focus public debates on "the social side of human nature; the responsibilities that must be borne by citizens, individually and collectively, in a regime of rights; [and] the fragile ecology of families and their supporting communities." Although communitarians claim to articulate

1. See The Responsive Communitarian Platform, at http://www.gwu.edu/ ccps/platformtext.html. 
a superior form of justice, they have largely overlooked the poor. By contrast, liberalism — as practiced by both those on the political left and right - has long been concerned with whether and how to alleviate poverty and injustice. ${ }^{2}$

Nevertheless, communitarian theory offers helpful insights into thinking about poverty and welfare. Under the current welfare law, enacted in 1996, thousands of families have been pushed off of public assistance and into unemployment or a low-paid workforce that strands them in poverty. It is time to think about welfare from a new perspective, and communitarianism provides one way to do that. Rather than making the individual the locus of blame and reform as current welfare law does, a community-based welfare system would seize upon the substantial reserves of social capital that exist within distressed neighborhoods to improve individual outcomes. While we currently ask the poor to work in exchange for welfare benefits, we do not reciprocate in turn by providing the needed supports that make work possible, such as child care, education, and transportation.

The communitarian conception of individuals as socially constituted holds out hope for a more holistic, and less reproachful, approach to social welfare policies. Our welfare policies have long been marked by a divide between the so-called deserving and undeserving and tailored in line with these moral judgments. Categories of persons deemed deserving - such as the elderly, disabled, and children-receive social insurance with no shame attached. By contrast, undeserving persons, a category that now includes any able-bodied adult, parent or otherwise, receive stingy and stigmatized welfare payments. Currently, to receive welfare payments under the Temporary Assistance to Needy Families program (TANF), recipients must work, as well as conform their behavior to prescribed values, and they cannot receive benefits for more than five years in a lifetime. ${ }^{3}$ The theoretical underpinning

The platform is also reprinted in Amitai Etzioni, The Spirit of Community: The Reinvention of Society 251-67 (1993) [hereinafter Etzioni, Spirit of Community].

2. To clarify, in this context, liberalism refers to our dominant political theory that views state neutrality and individual freedom to pursue one's chosen goals as essential to justice. It does not refer to "liberal" in the jargon of modern day politics, in which the liberal view is the opposite of conservativism, and is defined as favoring a more generous welfare state and greater social equality. Indeed, liberalism in the political theory sense encompasses both mainstream democratic and republican party political viewpoints; on both ends of the American political spectrum the emphasis is on maximizing the pursuit of individual ends. For political liberals this is achieved by providing needy individuals with the resources they need to meaningfully pursue their goals; for conservatives this is achieved by reducing the scope and reach of government. See generally Michael SANDEL, Democracy's Discontent 4-5 (1996) [hereinafter SAndel, Democracy's Discontent].

3. Personal Responsibility and Work Opportunity Reconciliation Act of 1996, Pub. L. No. 104-193, 110 Stat. 2105 (1996) (codified at 42 U.S.C. § 604(a) (2000)). 
of TANF is that personal character flaws cause poverty. Yet, if selfhood is shaped by communal connections, as communitarians maintain, it is clear that many persons deemed "undeserving" are not poor because of personal shortcomings, but rather, are subject to structural economic and demographic forces that have shaped their communities and that limit their range of options and influence their choices. Communitarians have not seized upon this insight; to the contrary, they appear to blame the poor for their plight. ${ }^{4}$ For instance, the communitarian platform states that every community member has an obligation to perform "honorable work," thereby implying that anyone who does not perform such work is dishonorable and ignoring the economic reality that there simply are not enough jobs for everyone who wants one.

In urging us to forge a model of social good that predominates over rights-based discourse, communitarianism also raises the possibility that one moral imperative could be the eradication of poverty. Yet, communitarian thinkers have never seized on this prospect. Although communitarianism has been widely applied as an analytic framework in a variety of contexts, ${ }^{6}$ its implications for poverty law and policy have not been closely examined. This may be due in part to a communitarian neglect of, and overall disinterest in,

4. This article is mindful that using the term "the poor," has the potential to mark low-income individuals as a separate, deviant class and blurs significant differences between and among poor people. See Thomas Ross, The Rhetoric of Poverty: Their Immorality, Our Helplessness, 79 Geo. L.J. 1499, 1499-1500 (1991). Moreover, by conceptualizing the poor as a monolithic community, this article also falls prey to Daniel Ortiz's critique of categorical community. Daniel R. Ortiz, Categorical Community, 51 Stan. L. Rev. 769, 806 (1999) ("Instead of simplifying identity in these dangerous ways, we should disaggregate and refine it - that is, acknowledge communities as fundamentally important but also as messily complex. In this view, individuals, instead of lying within a single community, would often lie at the intersection of many different ones."). Nevertheless, people who are unable to meet basic subsistence needs are bound by a commonality; American society has never fully recognized or responded to their needs. Accordingly, for lack of a better term, less loaded with cultural assumptions, this article uses the term "poor" to mean people who live in situations of economic deprivation.

5. See Responsive Communitarian Platform, supra note 1, at 7.

6. See, e.g., Robert M. Ackerman, Tort Law and Communitarianism: Where Rights Meet Responsibilities, 30 WAKe Forest L. Rev. 649 (1995); Gregory S. Alexander, Dilemmas of Group Autonomy: Residential Associations and Community, 75 Cornell L. Rev. 1 (1989); William T. Allen, Contracts and Communities in Corporation Law, 50 WASH. \& LeE L. Rev. 1395 (1993); Carlos A. Ball, Communitarianism and Gay Rights, 85 Corne Ll L. Rev. 443 (2000); Brandon P. Denning \& Glenn Harlan Reynolds, It Takes a Militia: A Communitarian Case for Compulsory Arms Bearing, 5 WM. \& MARY BILL RTS. J. 185 (1996); Mary Ann Glendon, Law, Communities, and the Religious Freedom Language of the Constitution, 60 Geo. WASH. L. Rev. 672 (1992); George C. Harris, The Communitarian Function of the Criminal Jury Trial and Rights of the Accused, 74 NeB. L. Rev. 804 (1995); David Schuman, Taking Law Seriously: Communitarian Search and Seizure, 27 Am. Crim. L. Rev. 583 (1990); Paul R. Tremblay, Toward a Community-Based Ethic for Legal Services Practice, 37 UCLA L. REv. 1101 (1990); Shirley Woodward, Debt to Society: A Communitarian Approach to Criminal Antiprofit Laws, 85 Geo. L.J. 455 (1996); Note, A Communitarian Defense of Group Libel Laws, 101 HARV. L. Rev. 682 (1988). 
social welfare issues. For a philosophy striving to articulate a superior method of achieving justice, communitarian thinkers have been strangely silent about rectifying the status of the poor. Unlike liberals, communitarians are not concerned with whether redistribution of wealth is a proper goal of the state. ${ }^{7}$ Instead, when communitarians address their normative goals, they tend to be concerned with reviving or creating shared moral obligations. When communitarians do discuss poverty, they tend to identify the many consequences of poverty-from crime to poor education to failing families - as causes of societal breakdown, rather than as symptoms. For communitarians, the consequences of poverty are often deemed repairable by a healthy dose of strong morals and deep community bonds; material assistance is generally not the preferred solution. To the contrary, some communitarians (like many of today's conservatives) blame material assistance for creating dependency among welfare recipients, who supposedly lack self-sufficiency and dignity as a result. Perhaps communitarians marginalize the problems of the poor because certain aspects of distressed communities undermine the rosy conceptions of community painted by communitarians, who tend to romanticize the mythical small-town America of yesteryear. Perhaps this marginalization results from the profound theoretical challenges the poor present to communitarian theory. ${ }^{8}$

Despite the communitarian neglect of poverty as a theoretical concern, communitarian principles have slowly seeped into our social welfare regime. Prior to TANF's enactment in 1996, the Aid to Families with Dependent Children (AFDC) program provided checks to welfare families based on objective eligibility criteria, and thus, reflected the classic liberal idea (albeit imperfectly realized) of providing people with enough material assistance to enable them to pursue their own objectives. ${ }^{9}$ By contrast, TANF's devolution of authority to local governments, private entities, and religious organizations; its emphasis on molding the behavior of the poor to conform to prescribed values; and its requirement of work as a reciprocal commitment owed by the

7. This is the core dispute within liberalism. Compare John Rawls, A TheORY of Justice (1971), with Robert Nozick, Anarchy, State, And Utopia (1974).

8. See Thomas W. Simon, The Theoretical Marginalization of the Disadvantaged: A Liberal/Communitarian Failing, in The Liberalism-Communitarianism Debate: Liberty and Community Values 103 (C.F. Delaney ed., 1994) (Simon argues that liberals and communitarians alike have "relegated disadvantaged groups ... to the theoretical margins"). Whatever the cause, this theoretical neglect is hard to justify in a country where 34.6 million people live below the poverty line and where one in six children live in poor families. Bernadette D. Proctor \& Joseph Dalaker, U.S. Census Bureau, Poverty in the United States: 2002, at 2, 7 (2003).

9. $\quad 42$ U.S.C. $\S \S 601-19$ (1994) (repealed 1996). 
poor to society, all have communitarian overtones. Communitarianism is suffused with themes of reciprocity, shared moral values, and the importance of mediating institutions such as schools, churches, and voluntary associations to fostering civic engagement. The influence of communitarianism on TANF may be due to the fact that the political implications of communitarianism are conservative in character. ${ }^{10}$ However, communitarianism need not necessarily lead to conservative policies, and some of its principal proponents are certainly embarrassed at the current, miserly state of American welfare policies. Unfortunately, Republicans have seized upon the malleability of communitarian discourse to make their anti-welfare policy prescriptions more palatable to the public, while Democrats have tried to mask their retreat from the poor with communitarian rhetoric. ${ }^{11}$ Given the seeming impact of communitarianism on poverty policies, the debate between liberalism and communitarianism is much more than an ivory tower exercise; it is relevant for anyone concerned about poverty.

Part I of this Article summarizes the tenets of communitarian political theory and the theory's inattention to issues of poverty. This Part explains that although TANF is imbued with communitarian rhetoric, it reflects a "thin" version of communitarianism that stresses the obligations the poor have to society, without any reciprocal notions of how society shapes and constrains the options available to the poor. At the same time, TANF's focus on reforming the behavior and structure of poor families looks like communitarianism at its most moralistic and authoritarian, the grounds on which communitarianism is most vulnerable to attack by supporters of liberalism.

10. See Amy Guttman, Communitarian Critics of Liberalism, in Communitarianism: A New Public Ethics 89, 95 (Markate Daly ed., 1994) (“Although the political implications of the communitarian criticisms of liberalism are conservative, the constructive potential of communitarian values is not.").

11. Both President Clinton, who signed the TANF legislation, and President Bush, who has attempted to expand the provision of faith-based social services, have been influenced by communitarianism. See, e.g., Eva Feder Kittay, A Feminist Public Ethic of Care Meets the New Communitarian Family Policy, 111 EтHICs 523, 526 (Apr. 2001) (noting the "access to political decisionmaking" by new communitarians); Karen J. Winkler, Communitarians Move Their Ideas Outside Academic Arena, 39 Chron. Higher Educ., Apr. 21, 1993, at A6 (noting appointment of William Galston, a prominent communitarian theorist, as deputy assistant to President Clinton for domestic policy); Dana Milbank, Needed: Catchword for Bush Ideology, WAsh. Post, Feb. 1, 2001, at A1 (describing President Bush's meetings with prominent communitarians); Michael Wines, Bootstraps: Not My Job, Not Our Job, So Whose Job Is It?, N.Y. Times, Apr. 9, 1995, § 4, at 1 (describing President Clinton's appropriation of communitarian themes in designing welfare reform). 
Part II analyzes the major works of three of the most prominent American communitarians, Michael Walzer, ${ }^{12}$ Michael Sandel, ${ }^{13}$ and Amitai Etzioni, ${ }^{14}$ in order to trace the roots of the reigning "thin" conception of community that seems to underlie both communitarian theory and its resultant incorporation into welfare law. Both Walzer and Sandel are political theorists who are concerned about inequities in American society (for different reasons), and each has insights that could be helpful to combating poverty. Walzer has an egalitarian vision of justice that calls for de-linking money from access to social institutions, while Sandel advocates for a renewed civic republicanism that requires shoring up community institutions. However, neither theorist has a rich conception of community that goes beyond seeing individuals as socially-constituted to consider how that process affects and constrains the poor. Walzer urges us to distribute social goods in line with society's shared understandings, but ignores the fact that marginalized groups have little role in shaping those understandings. Sandel emphasizes a renewed civic polity, but never addresses the barriers to political participation faced by poor communities. Etzioni is a sociologist and founder of the communitarian political movement. He advocates for a balance between rights and responsibilities as a way of correcting the excesses of American individualism. He, too, emphasizes the obligations the poor owe to society, but, like his more theoretical colleagues, does not develop a sophisticated vision of what society might owe the poor.

Accordingly, Part III suggests how a "thicker" version of community would not only enhance communitarian theory, but also result in more effective anti-poverty policies that build upon social capital in poor communities, rather than focusing simply on these neighborhoods' deficits. By examining four different ethnographic studies of urban poverty, this Part suggests that welfare reformers have largely ignored the social capital that exists even in extremely distressed neighborhoods. This article focuses on urban, African-American neighborhoods marked by concentrated poverty, because stereotypes about these neighborhoods and their residents were the impetus for and targets of welfare reform, and welfare reform was debated in

12. Michael Walzer, Spheres of Justice (1983).

13. Sandel, Democracy's Discontent, supra note 2; Michael Sandel, Liberalism and the Limits of Justice (2d ed. 1998) [hereinafter SANDEL, Liberalism].

14. Amitai Etzioni, Next: The Road to the Good Society (2001) [hereinafter Etzioni, Next]; Amitai Etzioni, The New Golden Rule (1996) [hereinafter Etzioni, New Golden Rule]; Etzioni, The Sirit of Community, supra note 1. 
race-conscious terms. ${ }^{15}$ Part IV suggests that welfare programs should respond to and be structured around communities, rather than focus solely on individual reform. This Part then sketches out a pragmatic vision of what a community-based social welfare policy would look like. The Article concludes that although communitarian thinkers have failed to grapple meaningfully with issues of poverty, communitarianism has the potential to broaden our response to poverty and to reform welfare in a way that could reinvigorate distressed communities without punishing their residents.

\section{The Communitarian Response to Liberalism}

In order to understand the communitarian critique, it is necessary to have some general understanding of what has triggered the ire of communitarian thinkers, namely, liberal political theory. The communitarian response to liberalism was galvanized by John Rawls's articulation of the liberal position in his book, $A$ Theory of Justice. The impact of this book on political theory cannot be understated; it "established the terrain upon which subsequent political-theoretical battles were to be fought."16 Accordingly, this section briefly summarizes the core of Rawls's theory, especially as it pertains to welfare issues. It then summarizes the communitarian critique of Rawls to highlight the essential differences between the two conceptions of justice.

\section{A. The Liberalism of John Rawls}

In $A$ Theory of Justice, John Rawls attempts to articulate the moral principles that should govern a just society. To do so, he hypothesizes a group of free, rational, and equal people building a just society from scratch and the principles to which they would agree. ${ }^{17}$ People in this "original position" are

15. See infra notes 309-92 and accompanying text. African-Americans are the largest group of welfare recipients by race (37.3 percent as compared to 35.8 percent of whites), and welfare recipients are disproportionately black. See Staff of House Comm. on Ways and Means, 106th Cong., 2000 Green Book: Background Materials and Data on Programs Within the Jurisdiction of the Committee on Ways AND MEans 438-39 (2000). It is important to note, however, that "other people of color are subject to welfare racist stereotypes similar to those imposed on African Americans, albeit to different degrees.” Kenneth J. Neubeck \& Noel A. Cazenave, Welfare Racism: Playing the Race Card Against America's Poor 148 (2001).

16. Adam Swift \& Stephen Mulhall, Liberals and Communitarians 1 (1992). The impact of Rawls on the law was the subject a recent symposium issue, Rawls and the Law, 72 FordHAM L. REV. 1381 (2004).

17. This was a reaction against and response to utilitarianism, which posits that the purpose of justice is to maximize the overall level of happiness without regard to impact on individual persons. 
denied certain information about themselves. For instance, they do not know their places in society, their social classes, their talents or abilities, or even their personal beliefs as to how they should lead their lives. ${ }^{18}$ This "veil of ignorance" ensures fairness in the negotiating process; that is, lacking information about inequalities, individuals cannot contract for their own advantage because they simply do not know what arrangement would benefit them. Moreover, the veil of ignorance ensures that parties in the original position will agree to principles that will protect them if they turn out to be at the bottom of the social ladder. ${ }^{19}$

As a first principle, Rawls concludes that parties in the original position would prioritize liberty above all other principles. ${ }^{20}$ The basic liberties Rawls has in mind include "political liberty (the right to vote and to be eligible for public office) together with freedom of speech and assembly; liberty of conscience and freedom of thought; freedom of the person along with the right to hold (personal) property; and freedom from arbitrary arrest and seizure as defined by the concept of the rule of law." ${ }^{21}$ Rawls also considers dignity to be a primary social good, and one that is fostered by his principles of justice. Thus, parties in the original position would do anything to avoid social conditions that undermine self-respect. ${ }^{22}$ Dignity is important because without it, "nothing may seem worth doing, or if some things have value for us, we lack the will to strive for them." ${ }^{23}$ Rawls thus argues that each individual has an inviolable dignity that should never be sacrificed for the welfare of society as a whole. As a result, the state must provide individuals with some minimal level of subsistence so that they can live fully human lives. ${ }^{24}$

Rawls's second principle of justice addresses issues of equality. According to the second principle, social and economic inequalities must operate to the greatest benefit of the least-advantaged (the difference principle) and offices and positions must be open to all under conditions of

18. RAWLS, supra note 7, at 136-37. They know only the "general facts about human society" such as politics, economics, and human psychology. Id. at 137.

19. See id. at 176 .

20. Under his first principle, "[e]ach person is to have an equal right to the most extensive total system of equal basic liberties compatible with a similar system of liberty for all." Id. at 302 .

21. Id. at 61 .

22. Id. at 440 .

23. Id. Rawls identifies two aspects of self-respect. "First ... a person's sense of his own value, his secure conviction that his conception of his good, his plan of life, is worth carrying out. And second, self-respect implies a confidence in one's ability, so far as it is within one's power, to fulfill one's intentions." Id.

24. Id. at 275 . 
fair opportunity (equal opportunity). The latter principle has priority over the former. Taken together, the two principles mean that "[a]11 social primary goods - liberty and opportunity, income and wealth, and the bases of selfrespect - are to be distributed equally unless an unequal distribution of any or all of these goods is to the advantage of the least favored." 25

Notably absent from the principles of justice is a substantive vision of how people should live their lives. To the contrary, Rawls places the right before the good ${ }^{26}$ In other words, people are free to pursue their own idea of the good life within the framework of the principles of justice. No particular way of life is deemed superior to another, and the vision allows for a plurality and diversity of ends. By placing the right before the good, Rawls situates individuals at the center of moral and political theory. The principles of justice give individuals room to "frame, revise, and rationally to pursue" their own visions of the good. ${ }^{27}$ Not surprisingly, then, the state must be neutral to allow individuals to pursue their own ends and should not endorse any particular conception of the good life. ${ }^{28}$ For Rawls, society is a system of mutual cooperation among individuals. As Rawls says, "a society is a more or less self-sufficient association of persons who in their relations to one another recognize certain rules of conduct as binding and who for the most part act in accordance with them. ${ }^{, 29}$ As a voluntary association of individuals, society is one of the many "goods" people can either pursue or retreat from if they so choose.

Unlike much of liberal and communitarian thought, Rawls is concerned with the plight of the disadvantaged, although he leaves this category illdefined. ${ }^{30}$ In addition to the equality principles noted above, Rawls asserts that people do not have a claim to the economic status they are born into or even their personal social endowments, such as intelligence or musical talent. In the parlance of political theory, this means that people are not entitled to their dessert. Rawls posits that these assets are no more than the result of happenstance and luck, and that therefore society has a claim to use such assets for the larger good. For Rawls, personal character "depends in large

\footnotetext{
25. Id. at 303 .

26. See id. at 447-48.

27. Id. at 60 .

28. Id. at 212 (stating that the government has "neither the right nor the duty to do what it or a majority ... wants to do in questions of morals and religion").

29. Id. at 4 .

30. See id. at 97-98. "[I]t seems clear that Rawls regards American society to be failing most significantly in matters of distributive justice, the distribution of social and economic benefits." Robert P. Burns, Rawls and the Principles of Welfare Law, 83 Nw. U. L. REv. 184, 194 (1989).
} 
part upon fortunate family and social circumstances for which [a person] can claim no credit." 31 Individuals must share their good fortune, either innate or inherited, with the larger society, so that the less-fortunate are on equal footing and better able to pursue their own individual ends. The ultimate goal is not enhancement of society as a group entity, but of individuals who operate within society.

Although Rawls is sympathetic towards the disadvantaged, scholars have struggled to apply his principles of justice to our social welfare system, due to their level of abstraction, their internal inconsistencies, and because Rawls does not seem to endorse the extreme consequences that some of his principles would compel. ${ }^{32}$ Notably, communitarians do not really engage Rawls either on the distribution or fair opportunity principles, those aspects of Rawlsian theory that most impact social welfare. ${ }^{33}$ Instead, they focus their energies on countering his conception of personhood as both inaccurate and undesirable. The communitarian approach thus actually coincides with our societal appropriation of Rawlsian liberalism. We do not live in the egalitarian state envisioned by Rawls; rather, "[o]ur current liberal state [is] structured by negative and atomistic rights, and committed to securing the minimal preconditions of participation . . . in a free society." ${ }^{34}$ While Rawls's emphasis on the autonomous individual is one that dominates our current political and legal thought, Rawls's equality principles have not been realized. So, in this sense, communitarians are aiming their ammunition at the aspect

31. RAwLS, supra note 7, at 104.

32. "Rawls' explicit statements on income maintenance policy are few and fragmentary, which is surprising in light of its importance to the plausibility of his theory and, as he would have it, its superiority over its rivals." Burns, supra note 30, at 238. Burns concludes that applying Rawls's principles would not lead to a just welfare system. For instance, Burns points out that while the difference principle ensures that income is distributed only if it also benefits the least advantaged, the resulting pattern of distribution would not necessarily satisfy basic needs. Id. at 204; see also William E. Forbath, Constitutional Welfare Rights: A History, Critique, and Reconstruction, 69 Fordham L. Rev. 1821, 1875 (2001) (concluding that Rawls would support work requirements); Amy L. Wax, Something for Nothing: Liberal Justice and Welfare Work Requirements, 52 EMORY L.J. 1, 37-45 (2003) (noting that Rawls is inconclusive as to whether a welfare system should require work).

33. See Swift \& Mulhall, supra note 16 , at xi.

34. Robin West, Rights, Capabilities, and the Good Society, 69 Fordham L. Rev. 1901, 1922 (2001) (lamenting the legal academy's abandonment of efforts to locate welfare rights in the Constitution); see also Burns, supra note 30, at 237-38. 
of liberalism most apparent in our societal arrangements. ${ }^{35}$ They are aiming at "liberalism's defects and excesses." 36

\section{B. The Communitarian Position}

Communitarians lament the liberal emphasis on individual rights and blame our rampant individualism for a long list of societal woes. For instance, Michael Sandel asserts that Americans are beset by widespread malaise and alienation because "we are losing control of the forces that govern our lives. ... [and] the moral fabric of community is unraveling around us." ${ }^{.37}$ Mary Ann Glendon echoes these concerns, stating that our obsession with defining and enforcing individual rights "promotes unrealistic expectations, heightens social conflict, and inhibits dialogue that might lead toward consensus." 38 Charles Taylor declares that the Western emphasis on individualism has led to a consumer society that results in "the meaningless subordination of work; the mindless lack of control of priorities; above all the fetishization of commodities." 39 For Taylor, liberalism results in people who are far less in control of their lives than the dominant ideology would suggest. ${ }^{40}$ The cure proposed by these and like-minded critics is a return to a civil society, undergirded by a commitment to a substantive set of moral values - the precise content of which communitarian minds debate.

As noted earlier, liberal theory hinges on the autonomy of the individual and the neutrality of the state. It pointedly does not concern the relation of the individual to communal groupings or the particular, substantive ends that people should pursue. By contrast, these are the core concerns of

35. Rawls responded to the communitarian critique in Political Liberalism, in which he moved away from the conception of personhood set forth in A Theory of Justice, and described the original position as a political conception that allows diverse voices to coexist peacefully through public reason without endorsing any comprehensive moral doctrine. John Rawls, Political Liberalism (1993). This article discusses Rawls only as background to understand the communitarian critique, and thus, it is outside the scope of this article to evaluate Political Liberalism.

36. Markate Daly, Introduction, in Communitarianism: A New Public Ethic xiii-xvi (Markate Daly ed., 1994); see also Linda C. McClain, Rights and Irresponsibility, 43 DukE L.J. 989, 1025 (1994) ("In many ways, the new communitarianism simply calls attention to the failures of American society to realize liberal principles and presuppositions about the requirements for a stable political order.").

37. SANDel, Democracy's Discontent, supra note 2, at 1.

38. Mary Ann Glendon, Rights Talk: The Impoverishment of Political Discourse 14 (1991).

39. Charles Taylor, The Modern Identity, in Communitarianism: A New Public Ethic, supra note 36 , at 64-65.

40. $I d$. 
communitarians, who view community, rather than liberty, as the primary value in society. For communitarians, it is wrong to conceive of individuals as unconnected and autonomous from their communities. ${ }^{41}$ "Man is a social animal, indeed a political animal, because he is not self-sufficient alone, and in an important sense is not self-sufficient outside a polis. ${ }^{" 42}$ Communitarians claim that the atomized view simply does not represent our real-life experience; it does not "make sense of our moral experience, because it cannot account for certain moral and political obligations that we commonly recognize, even prize." ${ }^{.43}$ In the communitarian vision, individual identity is derived from the complex web of human relationships and dependencies that constitute community, such as family, religion, and ethnic origin. So deep are these connections that it may be difficult, if not impossible, for people to separate themselves from them - or even to conceive of themselves apart from them. ${ }^{44}$

Because individuals are constituted and encumbered by their social attachments, they simply cannot be unmoored from their social contexts. For communitarians, our self-understandings are acquired from the "communities of culture and language that [we] create, maintain, and inhabit." ${ }^{45}$ Alisdair MacIntyre explains these connections as follows: "I inherit from the past of my family, my city, my tribe, my nation, a variety of debts, inheritances, rightful expectations and obligations. These constitute the given of my life, my moral starting point." ${ }^{\prime 6}$ This does not mean that individuals lack any

41. Communitarians, and Michael Sandel in particular, have been criticized for over-simplifying or misconstruing the liberal position. See, e.g., Will Kymlicka, Liberal Egalitarianism and Civil Republicanism: Friends or Enemies?, in Debating Democracy's Discontent 131-48 (Anita L. Allen \& Milton C. Regan, Jr. eds., 1998); Richard Rorty, A Defense of Minimalist Liberalism, in Debating Democracy's Discontent, supra at 117-18. See also Lawrence B. Solum, Situating Political Liberalism, 69 Chi.-Kent L. Rev. 549, 557-58, 557 n.43 (1994) ("The veil of ignorance is not intended to reflect a theory of the self; instead the veil provides a representation of a political idea about the freedom and equality of citizens."). (1985).

42. Charles Taylor, Philosophy and the Human Sciences: Philosophical Papers II 189-90

43. Sandel, Democracy's Discontent, supra note 2, at 13. Walzer notes the tension within communitarian doctrine between saying that liberalism describes how we live and at the sametime asserting that liberalism does not accurately describe the human condition. Michael Walzer, The Communitarian Critique of Liberalism, 18 POL. THEORY 6 (1990).

44. Communitarians tend to focus on involuntary, rather than voluntary, societal connections.

45. SWift \& Mulhall, supra note 16, at 162 . As Michael Sandel says, "community describes not just what [people] have as fellow citizens but also what they are, not a relationship they choose (as in a voluntary association) but an attachment they discover, not merely an attribute but a constituent of their identity." SANDel, Liberalism, supra note 13, at 150.

46. Alisdair Macintyre, After Virtue 205 (1981). 
autonomy whatsoever. To the contrary, an individual is "always open, indeed vulnerable, to growth and transformation in the light of revised selfunderstandings." 47 Or, put differently, just because we are socially constituted, does not mean we have to accept the "moral limitations of the particularity of those forms of community." although individuals can grow, change, and make choices, they do so against a background of values inherited from their communal experiences.

This concept of the socially constituted self leads communitarians to three major conclusions (although not all communitarians adhere to each of them). ${ }^{49}$ First, communitarians contend that because we are products of our particular communities, it is a mistake to try to derive and strive for universal principles of justice. Rather, such principles should be molded from common traditions and shared understandings of members in particular communities. This is not to say that community values always prevail. Communitarians attempt to distance themselves from the majoritarian or authoritarian implications of a community-centered philosophy. Rather, their insight is that people are products of community, including the reality that sometimes this can be a bad thing. Accordingly, they seek to encourage the growth and strengthening of "good" communities that foster specific, substantive values. ${ }^{50}$

Second, communitarians assert that pursuit of a common good allows us to live more fulfilling lives than the pursuit of individual interests. Communitarians contend that real people, those encumbered by communal connections, simply cannot be the autonomous free-choosers posited by liberalism. Choices are constrained by values that are generated and reinforced in communities. Thus, individuals should not be the focus of moral theory; rather, the focus should be on communities, where morals are defined. In turn, this gives a heightened importance to mediating institutions, such as schools, churches, labor organizations, neighborhood associations, and the like - those social groupings that stand between the individual and the state and provide people with both a buffer from state coercion and a source of moral guidance. It also means that the state has some role in supporting these

47. SANDel, Liberalism, supra note 13 , at 172.

48. MACINTYRE, supra note 46, at 205.

49. Indeed, communitarians resist the "communitarian" label that has been placed upon them by others. They go to pains to distinguish themselves from one another, but they share an underlying commitment to revitalizing a sense of community that they believe has been lost to liberal values. See Daly, supra note 36, at xiv. For a detailed discussion of the distinction between the various strands of communitarianism see Stephen A. Gardbaum, Law, Politics, and the Claims of Community, 90 Mich. L. REV. 685 (1992).

50. See Daly, supra note 36 , at xiv. 
sorts of institutions. For communitarians, the strength of mediating institutions is a bulwark against oppression, as they disperse power and involve citizens in a politics of the common good. ${ }^{51}$

Third, communitarians reject the liberal philosophy of putting the right before the good. They place the good before the right. In so doing, they reject the notion of the atomistic self as not only unrealistic, but also normatively unpalatable. As Michael Walzer states, "[i]t generates a radical individualism and then a radical competition among self-seeking individuals." ${ }^{.52}$ Rawls contends that the state should separate moral issues from political debates. ${ }^{53}$ By contrast, communitarians contend that "rights depend for their justification on the moral importance of the ends they serve." ${ }^{54}$ As they see it, the state does not need to be neutral if there are things we can and should agree on. Not surprisingly, there is a strong strand of civic republicanism that runs throughout communitarian thinking. Meaningful participation in political life is one dominant vision of the "good." Communitarians also stress a long list of other civic virtues, such as reciprocity, trust, tradition, solidarity, and interdependence. ${ }^{56}$

\section{The Communitarian Influence in Social Welfare}

TANF reflects these communitarian ideals in three major ways: (1) by endorsing reciprocity over rights; (2) by attempting to shape the behavior of welfare recipients to conform with notions of the common good; and (3) by devolving authority over welfare to the state and local governmental levels, as well as to mediating institutions, such as private for-profit, non-profit, and religious entities.

51. See Shlomo Avineri \& Avner De-Shalit, Communitarianism and Individualism 9 (Vernon Bogdanor \& Geoffrey Marshall eds., 1992).

52. Michael Walzer, Radical Principles: Reflections of an Unreconstructed Democrat 92, 98 (1980).

53. Rawls, Political Liberalism, supra note 35 , at xx, xxviii.

54. SANDEL, Liberalism, supra note 13 , at xi.

55. See Benjamin Barber, Strong Democracy: Participatory Politics for a New Age xv (1984) ("Without participating in the common life that defines them and in the decision-making that shapes their social habitat, women and men cannot become individuals.").

56. Elizabeth Frazer, The Problems of Communitarian Politics: Unity and Conflict 22-23 (1999). 


\section{Reciprocity}

To begin with, TANF stresses the "good" of reciprocity over the "right" to a categorical entitlement. AFDC provided open-ended federal funding for welfare and a guarantee of assistance to all eligible persons. It was an entitlement, and thus reflected liberal ideals. ${ }^{57}$ By contrast, under TANF, states receive fixed block grants to deliver welfare; the size of the block grant is based upon AFDC expenditures in 1994. The statute expressly states that TANF benefits are not an entitlement. ${ }^{58}$ Indeed, states do not have to provide cash assistance at all with their block grant funds; rather, they may use TANF funding in any manner "reasonably calculated to accomplish the purpose of [TANF]. ${ }^{59}$ The stated purposes of the TANF program are to reduce welfare dependency and out-of-wedlock births and to encourage the formation of twoparent families. ${ }^{60}$

The theme of reciprocity is manifested in TANF's work requirements. In the 1980s, conservative scholars began to vigorously attack welfare as the source of a weakened work ethic among the poor, as well as a variety of social pathologies. ${ }^{61}$ By contrast, work led to "social functioning" and engagement in the social contract. Both Republicans and Democrats quickly seized upon the notion of work as a basic American value and necessary to social citizenship..$^{62}$ For instance, David Ellwood, an Assistant Secretary of Health and Human Services under President Clinton, argued that welfare was a failure and that the American ideal was "a guarantee that people who strive and who meet reasonable social responsibilities will be able to achieve at least a modest level of dignity and security." ${ }^{93}$ TANF embodies these notions

57. The Supreme Court held that AFDC was an entitlement, and not a mere privilege, in Goldberg v. Kelly, 397 U.S. 254, 262 (1970).

58. 42 U.S.C. $\S 601(b)(2000)$

59. Id. $\S 604(\mathrm{a})$.

60. Id. $\S 601(\mathrm{a})$

61. The conservative attack on welfare was set forth in Lawrence Mead, Beyond Entitlement: The Social Obligations of Citizensh ip (1986) (stating that work should be a condition of welfare) and Charles Murray, Losing Ground 227-33 (1984) (arguing that welfare should be abolished).

62. See Kathleen A. Kost \& Frank W. Munger, Fooling All of the People Some of the Time: $1990 \mathrm{~s}$ Welfare Reform and the Exploitation of American Values, 4 VA. J. Soc. PoL'Y \& L. 3, 25-34 (1996).

63. David Ellwood, Poor Support 44 (1988). See also Judith M. Gueron, Welfare and Poverty: The Elements of Reform, 11 YALE L. \& PoL'y ReV. 113 (1993) ("For the last thirty years, there has been widespread agreement that the nation's welfare system should be reformed to make it more consistent with basic public values endorsing the primacy of family and the importance of work."). 
(although it takes the work requirements to a punitive level not endorsed by Ellwood and many other Democrats ${ }^{64}$ ).

Although states have great flexibility in designing their own welfare programs, they must adhere to the federal requirement that all TANF recipients engage in "work activity" within two years of getting benefits ${ }^{65}$ and are subject to a five-year lifetime limit on the receipt of benefits. ${ }^{66}$ States can choose to shorten these maximum time limits, and indeed, twenty states have a lifetime limit that is shorter than five years. ${ }^{67}$ Failure to comply with TANF's work requirements results in sanctions that reduce or eliminate benefits. $^{68}$ The TANF work requirements mean that single-mothers-the primary recipients of welfare benefits - must work outside the home. ${ }^{69}$ By contrast, under TANF, women who marry are permitted to work inside the home. $^{70}$

\section{Incentives to Change Behavior}

This marriage incentive is one of the many ways in which TANF aims to shape the behavior of poor, single women to conform to patriarchal notions of the common good. There are other behavioral modification mechanisms. For instance, under TANF, minor parents (those under eighteen) are denied benefits unless they live with an adult and attend school or another approved training program. ${ }^{71}$ Also, states must reduce a family's benefits by twenty-five

64. Jason DeParle, The Ellwoods: Mugged by Reality, N.Y. Times Mag., Dec. 8, 1996, at 64 (describing welfare reform as a "corruption" of Ellwood's ideas and explaining that Ellwood proposed accompanying welfare time limits with "universal health care, expanded training programs, wage supplements, guaranteed child support and last-resort Government jobs").

65. 42 U.S.C. $\S 602(a)(1)(A)($ ii) (2000).

66. Id. $\S 608(\mathrm{a})(7)$.

67. See State Policy Documentation Project, Findings in Brief: Time Limits, State Policy Documentation Project, at http://www.spdp.org/tanf/timelimits/timelimitexpl.htm (last modified July 20, 2000).

68. It is estimated that twenty-five percent of the welfare caseload is under sanction. See SHARoN Hays, Flat Broke With Children 41 (2003).

69. See id. at 11. Over ninety percent of welfare clients are mothers, most of whom are raising their children alone. $I d$. Only seven percent of welfare cases consist of two-parent households. Id. States may exempt mothers with children under the age of one from work requirements, 42 U.S.C. § 607(b)(5) (2000), and they must lift work requirements for mothers with children under the age of six if the mother can prove that she cannot obtain "appropriate or affordable" child care. Id. §607(e)(2).

70. Single mothers have long been the subject of moral regulation through welfare policies. See Gwendolyn Mink, Welfare's End 103-08 (1998); Linda Gordon, Pitied but not Entitled: Single Mothers and the History of Welfare: 1890-1935(1994); MimiAbramovitz, Regulating the Lives of Women: Social Welfare Policy from Colonial Times to the Present (rev. ed. 1996).

71. 42 U.S.C. $§ 608(a)(4),(5)(2000)$. There are some limited exceptions to this rule if an adult 
percent if the mother fails to establish the paternity of her children born out of wedlock. ${ }^{72}$ In addition, states can choose to deny benefits to children born while their family is receiving benefits, ${ }^{73}$ to sanction families that include adults under age fifty-one who neither have, nor are seeking, a high school diploma ${ }^{74}$ to declare noncitizens ineligible for assistance ${ }^{75}$ or to cut benefits to families with truant children. ${ }^{76}$ To effectuate the massive shift in expectations mandated by TANF, all states require welfare recipients to sign either personal responsibility contracts or employability plans, and some states require both. ${ }^{77}$ Personal responsibility contracts hold recipients to a variety of commitments, such as participation in work activities, child and/or minor parent school attendance, cooperation with child support enforcement requirements, child immunization or preventive health measures, participation in life skills or parenting training, substance abuse provisions, and agreements to achieve self-sufficiency within a set time period.

\section{Mediating Institutions}

The communitarian emphasis on local collectives is manifested in TANF's devolution of authority to administer welfare from the federal government down to the states and local governments. Proponents of devolution argue that it allows the states to become laboratories for innovation and efficiency, to craft policies that best meet the needs of their distinct populations, and to better mobilize community resources. TANF also allows

relative is not available or where the placement could result in harm to the parent and/or child. Id. $\S 608(a)(5)(B)$.

72. Id. $\S 608(\mathrm{a})(2)$.

73. Twenty-one states have family cap policies, which deny incremental benefits for children born to parents receiving welfare. See Family Cap: Overview, State Policy Documentation Project, at http://www.spdp.org/famcap/famcapover.htm (last visited Feb. 7, 2005).

74. 42 U.S.C. $§ 604(j)(2000)$.

75. Legal immigrants are restricted from receiving TANF benefits for their first five years in the United States; no federal benefits may be awarded to undocumented immigrants. 8 U.S.C. $\S 1611$ (a) (2000). For a discussion of the complicated welfare rules now governing immigrants, see John Fredriksson, Bridging the Gap Between Rights and Responsibilities: Policy Changes Affecting Refugees and Immigrants in the United States Since 1996, 14 Geo. Immigr. L.J. 757 (2000).

76. 42 U.S.C. $\$ 604(i)$ (2000). States can also elect whether or not to adopt exemptions that stop the five-year clock from running. Eighteen states have no time limit exemptions; that is, the clock runs in those states even where the wage earner is disabled, a victim of domestic violence, or pregnant. See Findings in Brief: Time Limits, State Policy Documentation Project, at http://www.spdp.org/tanf/ timelimits/timelimitexpl.htm (last visited Feb. 7, 2005).

77. See Christine M. Cimini, The New Contract: Welfare Reform, Devolution, and Due Process, 61 MD. L. Rev. 246, 258-59 (2002). 
for a second-level of devolution from the states to private non-profit, forprofit, or religious entities. ${ }^{78}$ The privatization of welfare is fueled by dissatisfaction with the bureaucratic nature of government-run welfare offices and a perception that private entities are cheaper, more innovative, and more efficient. In addition, some advocates claim that privatization can be a democratizing force that shifts power from the government to local communities and their mediating institutions, such as churches, neighborhoods, and voluntary organizations, which are better situated to address a community's needs. ${ }^{79}$ Under TANF's charitable choice provision, governments can pay religious organizations such as churches, synagogues, and mosques to deliver welfare services. Charitable choice is founded on the idea, albeit empirically unproven, that a spiritual approach to solving social problems is superior to a secular one. It thus enhances the role of religious organizations in solving our public problems.

\section{Community Values and Communitarian Politics}

TANF is also arguably communitarian in that it reflects "[c]ommunity expectations and values" 80 of the "mainstream" public, which became disillusioned with the dependency AFDC seemed to foster, as well as a perceived breakdown in family values among the poor. For that reason, some communitarians might view TANF as a legislative expression of the public will. ${ }^{81}$ This raises some of the liberal critiques of communitarian theory. Progressive liberals might counter that we should not endorse laws that are based on misperceptions and inaccuracies ${ }^{82}$ that impose the will of the majority on a politically powerless minority, and that leave little room for individual rights. Communitarians have paid scant attention to issues surrounding welfare, and thus, they have not articulated a response to this critique.

78. See Michele Estrin Gilman, "Charitable Choice" and the Accountability Challenge: Reconciling the Need for Regulation with the First Amendment Religion Clauses, 55 VAND. L. Rev. 799 , 806-09 (2002) [hereinafter Gilman, Charitable Choice].

79. Michele Estrin Gilman, Legal Accountability in an Era of Privatized Welfare, 89 CAL. L. REv. 569, 596 (2001) [hereinafter Gilman, Accountability].

80. Isabel V. Sawhill, The New Paternalism: Earned Welfare, in RightS AND the Common Good: The Communitarian Perspective 131, 133 (Amitai Etzioni ed., 1995).

81. Id. at 134 (discussing the "community's right (subject to constitutional limitations) to express its values through the political system").

82. See infra Part I.E. 
It goes too far to say that communitarians constitute a powerful political block that seized control over the political process that reformed welfare. Yet communitarianism provided much of the language and rhetoric that allowed conservatives to dramatically cut welfare supports, while providing cover for Democrats to claim that they were restoring dignity to the poor. In particular, President Clinton was very influenced by communitarian thinking in shaping his centrist Third Way and his pledge to "end welfare as we know it," and he appointed several self-identified communitarians to prominent government posts. ${ }^{83}$ Despite disagreements about the level of support that should be provided to welfare recipients, both conservatives and liberals focused "public attention on the qualities that distinguish the stereotypical welfare recipient from the mainstream," and they were thus able to "shift the emphasis of public discourse away from poverty, to the deviant behavior of recipients." ${ }^{84}$ In addition to stressing the moral depravity of the poor, welfare reformers utilized communitarian notions about social citizenship and family values that made the punitive provisions in TANF palatable across the political spectrum.

\section{An Assessment of TANF}

Because TANF reflects some communitarian influence, one possible way to ask whether communitarianism is good for the poor would be to ask whether TANF has been a success. By this measure, communitarianism is an abysmal failure, particularly if we conceive of TANF as our communal commitment as a nation to our most disadvantaged citizens. Under TANF, the numbers of people on welfare have dropped dramatically; there are half as many people on welfare today as there were in $1996 .{ }^{85}$ Despite these

83. For a legislative history of TANF's enactment, see Hugh Heclo, The Politics of Welfare Reform, in The New World of Welfare 169-94 (Rebecca Blank \& Ron Haskins eds., 2001).

84. See Kost \& Munger, supra note 62 , at 28.

85. Researchers debate whether the dramatic drop in welfare recipients was due to TANF, the economy (which was strong immediately following TANF's enactment), or to other support policies such as the Earned Income Tax Credit. See Alan Weil \& Kenneth Finegold, Introduction, in WeLfare Reform: The Next Act xx-xxi (Alan Weil \& Kenneth Finegold eds., 2002) [hereinafter The Next Aст].

The number of welfare recipients was already falling prior to 1996, but continued to drop dramatically after TANF was adopted. Between 1996 and 2000, a period marked by a robust economy, the number of people receiving welfare dropped by half, see id. at xx, although caseloads in most states started to rise again slightly by 2001 and then to continue to fluctuate mildly or remain flat. The Center for Law and Policy has a series of detailed reports available on their website tracking the welfare caseloads at www.clasp.org. See, e.g., Hedieh Rahmanou \& Mark Greenberg, Welfare Caseloads Increase in 27 States Between June and September 2003, Center for Law and Social Policy, available at http://www.clasp.org/ publications/TANF_pr_021704.pdf. 
encouraging numbers, the actual living situations of most current and former welfare recipients are bleak, because most people who leave welfare remain below the poverty line, while others are unemployed and disconnected from the welfare system. ${ }^{86}$ Many former welfare recipients are working in lowwage jobs with few benefits and are no longer receiving food stamps or Medicaid coverage, even where eligible. ${ }^{87}$ Often, income gains from employment are reduced by the loss of public benefits and are eaten up by the very costs of working - child care, transportation, uniforms, and the like. Slightly under half of welfare leavers are working, ${ }^{88}$ and, of those, sixty percent remain below the poverty line. ${ }^{89}$ Up to a third of those who leave welfare for work are back on welfare within a year, unable to procure steady work or reliable childcare. ${ }^{90}$ Moreover, about forty-five percent of families who are eligible for TANF are not receiving it, meaning that "many, if not most, poor families are disconnected from the welfare system." 91 Some of these families are discouraged from applying for benefits, many are sanctioned (often incorrectly) for failing to meet program requirements, and others simply disappear from the system. ${ }^{92}$ In addition, there is a core of TANF recipients who face severe barriers to work, such as illiteracy, lack of education, physical and mental health problems, domestic violence, or drug or alcohol

86. Regarding the effectiveness of TANF, Sharon Hays estimates from a review of welfare studies that ten to fifteen percent of welfare mothers are in a better position post-TANF, and stresses that increased child care subsidies, income supplements, bus vouchers, and other benefits spurred by TANF have been helpful for some recipients. Yet overall, "in the long run and in the aggregate, poor mothers and children are worse off now than they were prior to reform." HAYs, supra note 68, at 225-26.

87. See Pamela J. Loprest, Fewer Welfare Leavers Employed in Weak Economy, 5 SnAPSHOts of AmericA's FAms. (Urban Institute), Aug. 2003, at 3 [hereinafter Loprest, Fewer Welfare Leavers]. Onethird of people who have left welfare are working part-time, one-third have health insurance, and onequarter work jobs with irregular hours. See Pamela J. Loprest, Making the Transition from Welfare to Work: Successes but Continuing Concerns, in The NeXT Act, supra note 85, at 17, 20 [hereinafter Loprest, Making the Transition].

88. See Loprest, Fewer Welfare Leavers, supra note 87, at 3.

89. The poorest of the poor are getting poorer. "The number of persons in independent single-parent families who lived in extreme poverty increased ...." Sheila R. Zedlewski, Family Incomes: Rising, Falling, or Holding Steady?, in The NeXt ACt, supra note 85, at 70. Disposable income for single-parent families in the bottom income quintile declined by eight percent between 1996 and 1998. Id.

90. See Loprest, Making the Transition, supra note 87, at 22 .

91. See Fragile Families Research Brief, Variations in Maternal and Child Wellbeing by TANF Eligibility and Participation (October 2003). These families chose not to apply, were deterred from applying (perhaps because of fears of hitting the lifetime limit), or were not actually eligible due to immigration status. Fourteen percent of people who left welfare had no sources of income in 2002. See Loprest, Fewer Welfare Leavers, supra note 87, at 1.

92. See HAYs, supra note 68 , at 222-24. 
dependency. ${ }^{93}$ These families face statutory time limits with no clear policy approaches for dealing with or removing these barriers.

In assessing the effects of TANF, it is also important to consider the noneconomic aspects of family well-being. After all, TANF's express purposes are to foster family formation by increasing marriage in order to improve the well-being of children, who constitute the majority of welfare recipients. Accordingly, in addition to the work requirements, TANF allows states to provide a variety of social services to low-income families (a group broader than welfare recipients), including job training, child care, and transportation, as well as services related to mental health and substance abuse, family planning, parenting education, and domestic violence. ${ }^{94}$ Research concerning the impact of TANF on child welfare is limited and inconclusive because of the complexity of isolating causality. ${ }^{95}$ Overall, studies reveal that TANF has not had a significant influence one way or the other on children in families that receive welfare, although there are some troubling indicators for teenagers. ${ }^{96}$ Children in families that receive welfare and in families that have left welfare are both at risk for poor development outcomes, and "there have been no major shifts in well-being for either group." ${ }^{, 97}$

Although there is little research on the impact of TANF on child maltreatment, some studies have suggested that reductions in welfare benefits are linked to increased entry into the child welfare system, particularly if the mother does not obtain subsequent employment. ${ }^{98}$ Studies have also shown

93. See Loprest, Making the Transition, supra note 87, at 22-23. Fifty-one percent of welfare leavers with no barriers were working in 2002; while only fourteen percent of welfare leavers with two or more barriers were working. Sheila R. Zedlewski, Work and Barriers to Work Among Welfare Recipients in 2002, 3 Snapshots of America's Fams. (Urban Institute), Aug. 2003, at 1.

94. See Rutledge Q. Hutson, Red Flags: Research Raises Concerns About the Impact of "Welfare Reform" on Child Maltreatment, Center for Law and Social Policy, Oct. 2001, available at http:// www.childrensrights.org (last visited Feb. 25, 2005).

95. For instance, in 1993, the number of child maltreatment cases began decreasing, and this has continued post-TANF. At the same time, post-TANF, the number of children in foster care has grown. It is hard to isolate the cause of these trends. Hutson, supra note 94, at 9-10.

96. See Issue Brief, Child and Youth Well-Being Under Welfare Reform: Recent Research (NGA Center for Best Practices), Jan. 2004, at 1. While elementary age children in welfare families appear to be achieving some gains in school achievement and behavior, teen-age children are showing some negative impacts, through poor school achievement, increases in drinking and smoking, and problem behavior. Id. at 1-4; Greg J. Duncan \& P. Lindsay Chase-Lansdale, Welfare Reform and Child Well-Being, Northwestern University, available at http://www.icpr.org (last visited Feb. 25, 2005). This may be due to decreased parental supervision and/or increased child care responsibilities for teenagers who must care for their younger siblings. Martha Zaslow et al., How Are Children Faring Under Welfare Reform?, in THE NeXT ACT, supra note 85 , at 82 .

97. Weil \& Finegold, in The NeXt Act, supra note 85 , at xxii.

98. See Hutson, supra note 94. 
that rates of neglect increase as the share of single working mothers increase, and, conversely, that states with more generous welfare benefits have lower numbers of neglect cases. ${ }^{99}$ Not surprisingly, poor families do better in jurisdictions with more work support services, such as job training, health insurance, income supplements, and subsidized child care. ${ }^{100}$ Anecdotal surveys of child welfare officials reveal that some states have seen an increase in neglect cases based on inadequate supervision; one state reported a $150 \%$ increase in the number of such cases. ${ }^{101}$ Moreover, several of these state officials report that more parents were turning their children over to the child welfare system or delaying reunification with their children in foster care. ${ }^{102}$ These studies raise concerns about the possible impact of TANF, although the evidence to date is inconclusive.

TANF also has not achieved significant progress in increasing marriage rates or reducing single-parent families, the express purposes of the Act. For instance, there is no statistically significant link between TANF and the reduction in teenage parenthood. Although teenage birth rates are falling, they began decreasing before TANF, and seem to be neither harmed nor helped by welfare reform. ${ }^{103}$ In contrast to the positive decrease in teenage birth rates, post-TANF birthrates among single women between the ages of eighteen and twenty-nine have actually risen. ${ }^{104}$ Marriage rates are up for some low-income groups and down for others, but the proportion of married women overall continues to decline. ${ }^{105}$ Thus, researchers have concluded that TANF has achieved "mixed progress on family structure objectives." clear that the work objectives and the family objectives of TANF often conflict, making it difficult for states or families to achieve significant improvements in both areas simultaneously.

Yet this bleak picture does not mean that communitarianism is bad for the poor, because TANF is far from a fully-realized version of communitarianism. Despite its stated norms of reciprocity and family values, and despite its

99. See id.

100. See Duncan \& Chase-Lansdale, supra note 96. See also Children in Low Income Families Fare Better with Work Supports, The Forum (Nat'l Ctr. for Children in Poverty) Oct. 2003.

101. See Hutson, supra note 94.

102. See id.

103. See Gregory Acs \& Heather Koball, TANF and the Status of Teen Mothers Under Age 18(Urban Institute), June 2003, at 1-2. The decrease in teen mothers predates TANF. See Robert I. Lerman, Family Structure and Childbearing before and after Welfare Reform, in THE NEXT ACT, supra note 85, at 42-43.

104. See Lerman, supra note 103 , at 43.

105. See id. at $45-46$.

106. See id. at 46. 
reliance on communal organizations to deliver welfare, TANF still focuses relentlessly on its version of the moral improvement of individuals. It provides little for improvement of the communities in which poor people live. It thus "denies the embeddedness of all individuals in the wider society and their reliance on it" ${ }^{\prime 107}$ in a manner inconsistent with communitarianism.

\section{E. The Causes of Poverty}

TANF's theoretical foundation is that individual choices cause poverty, in particular, the individual choices of African-American residents of inner city neighborhoods marked by concentrated poverty. Although AfricanAmericans only account for one-quarter of the poverty population, ${ }^{108}$ and although few welfare recipients have lifelong dependency on welfare, the dialogue and debate surrounding welfare reform centered on a culture of pathology among inner-city African-Americans. In the 1980s, conservative critics of welfare focused on a culture of poverty within the urban underclass and claimed that welfare induced laziness, dependency, promiscuity, immorality, and deviancy among recipients. ${ }^{109}$ These theorists maintained that the inner-cities are plagued by a deviant counter-culture that rejects mainstream values. ${ }^{110}$ The media and politicians picked up on these cultural explanations for poverty, and began demonizing the "welfare queen," a term popularized by President Reagan, which referred to a "woman of color who manipulates and exploits the welfare system, scorns lasting or legalized relationships with men, and has a series of children out of wedlock in order to continue her welfare eligibility." 111 The welfare queen was a member of the "underclass," which was viewed as "a mysterious wilderness in the heart of

107. HaYs, supra note 68 , at 216 .

108. See John Iceland, Poverty in America 3 (2003). African-Americans do, however, suffer a poverty rate almost twice that of the national poverty rate. $I d$. at 81 .

109. See E. Douglass Williams \& Richard H. Sander, The Prospects for "Putting America to Work" in the Inner City, 81 GEO. L.J. 2003, 2035-36 (1993).

110. Id. at 2036. There are at least two strands to this behavioral explanation for poverty. Some culture of poverty theorists such as Charles Murray maintained that people made rational economic choices to stay on AFDC, and that elimination of welfare would solve poverty. Other theorists stressed the "bad" family choices of welfare recipients to forgo marriage and to have children out of wedlock, and posited that "better" behavior would solve poverty. See Williams \& Sander, supra note 109, at 2035-41.

111. See Nina Perales, A "Tangle of Pathology": Racial Myth and the New Jersey Family Development Act, in Mothers in Law: Feminist Theory and the Legal Regulation of Motherhood 250, 257-58 (Martha Albertson Fineman \& Isabel Karpin eds., 1995). See also Joel Handler, Ending Welfare as We Know It-Wrong for Welfare, Wrong for Poverty, 2 Geo. J. on Fighting Poverty 3, 7 (1994). 
America's cities; a terrain of violence and despair" ${ }^{\prime 12}$ marked by drugs, crime, teenage pregnancy, high unemployment, and welfare. ${ }^{113}$ The welfare queen subsequently became a frequent target during the racially tinged debates over welfare reform in the 1990s. ${ }^{114}$

While the problems associated with poverty are real and serious, TANF creates inadequate solutions because the legislation was built on a series of myths. ${ }^{115}$ For instance, TANF is a response to perceived welfare dependency, yet only a small minority of AFDC recipients stayed on welfare for more than six years. ${ }^{116}$ Most welfare recipients use welfare for a short-term spell, or cycle on and off for short periods as economic circumstances dictate. ${ }^{117}$ TANF also assumes a culture of poverty that is passed from generation to generation, and that is marked by promiscuity and large families; these claims are likewise false. ${ }^{118}$ Moreover, TANF is founded on the simplistic notion that refusal to work is the reason for poverty, when, in truth, millions of full-time

112. Michael Katz, Improving Poor People 64 (1995).

113. See Michael Katz, The "Under class" Debate 4 (1993) (quoting a 1977 Time Magazine story describing the underclass as follows: "Behind the [ghetto's] crumbling walls, lives a large group of people who are more intractable, more socially alien and more hostile than almost anyone had imagined. They are the unreachables: The American underclass.").

114. During the debates on welfare reform, poor mothers on welfare were referred to at various times as "breeding mules," "alligators," and "monkeys." For instance, House Ways and Means Chair, Rep. Clay Shaw Jr. said, "It may be like hitting a mule with a two-by-four, but you've got to get their attention." Louis Kushnik, Responding to Urban Crisis, Functions of White Racism, in A New InTRoduction to Poverty: The Role of Race, Power, and Politics 147, 160 (Louis Kushnick \& James Jennings eds., 1999). See also Neubeck \& Cazenave, supra note 15, at 169-70. For a detailed description of the racist underpinnings of the welfare system, see Jill Quadagno, The Color of Welfare: How Racism Undermined the War on Poverty (1994).

115. See generally Mink, supra note 70, at 33-35; Valerie Polakow, Savage Distributions, Welfare Myths and Daily Lives, in Anew Introduction to Poverty: The Role of Race, Power, and Politics, supra note 114, at 241,246-48; Handler, supra note 111; Kost \& Munger, supra note 62, at 34; Sylvia Law, Ending Welfare As We Know It, 49 Stan. L. Rev. 471, 483 (1997); Morgan B. Ward Doran \& Dorothy E. Roberts, Welfare Reform and Families in the Child Welfare System, 61 MD. L. Rev. 386, 399-402 (2002); Lucy A. Williams, Race, Rat Bites and Unfit Mothers: How Media Discourse Informs Welfare Legislation Debate, 22 Fordham Urb. L.J. 1159 (1995); Note, Dethroning the Welfare Queen, The Rhetoric of Reform, 107 HARV. L. Rev. 2013 (1994).

116. See Law, supra note 115, at 476-79 (summarizing research from monthly data on welfare populations). Moreover, culture of poverty theorists, such as Charles Murray, could never explain why welfare rolls increased as the value of benefits decreased. See Michael Katz, The Price of Citizenship: Redefining the Welfare State 320 (2002) [hereinafter Katz, The Price of Citizenship].

117. See Handler, supra note 111, at 14.

118. See id. at 7. Welfare families are no larger than non-welfare families, and the growth in singleparent families has occurred across class lines. In addition, most daughters (sixty-four percent) who grew up in AFDC dependent households did not become welfare dependent themselves, although "there is a higher likelihood of welfare receipt among women with welfare backgrounds" due to the effects of poverty and single parenthood. Id. at 14-15. 
workers do not earn enough to lift themselves out of poverty and there are not enough jobs available for everyone who needs one. ${ }^{119}$ As opposed to the stereotype of the welfare queen, most welfare recipients show adherence to a work ethic; indeed, they have long worked part-time and/or earned unreported income in order to meet basic expenses. ${ }^{120}$ In-depth surveys reveal that innercity residents share the values of hard work and the aspirations of mainstream society, although a lack of education and jobs make it much harder for some urban poor to put these values into practice. ${ }^{121}$ Moreover, social problems identified with and blamed on the underclass - such as a rise in singleparenting, crime, and drugs - cut across all economic classes. ${ }^{122}$

The cultural explanation of poverty is founded on conjecture masquerading as common sense, but it has no empirical support. ${ }^{123}$ Nevertheless, it has had remarkable staying power because it demands less from government and it appeals to the economically insecure middle class. ${ }^{124}$ By contrast, the real causes of poverty are far more complex. To begin with, an amalgamation of economic and demographic factors contribute to poverty, including declining labor market opportunities, the erosion of the minimum wage and low-wage income, deindustrialization, technological changes in the economy, globalization, the decline of unions, and the increased use of contingent workers who are low-wage, part-time, and lack benefits. ${ }^{125}$

119. See infra notes 461-65 and accompanying text. "Although causality is not well understood, the fact remains that poverty, and not welfare dependency, is the single most powerful predictor of the harmful behavioral consequences that we ascribe to welfare families." Handler, supra note 111, at 8 (noting that welfare population is much smaller than the poverty population).

120. Id. at 15-16. Indeed, in a study of AFDC recipients in Chicago in the late 1980s, researchers found that most welfare recipients were working in order to meet basic expenses, but were not reporting this income. Id. at 15 . Moreover, most welfare recipients regularly cycle off of welfare for work because of the precarious nature of the low-wage workforce. Id. at 16. See also Polakow, supra note 115, at 247 ("The reality is that most women on welfare have worked part time, and many are cyclical part-time workers forced out of the labor market by lack of jobs, layoffs, and/or ever-pressing needs for health care and child care.").

121. See William Julius Wilson, When Work Disappears 179-81 (1996).

122. See Peter Dreier et al., Place Matters: Metropolitics for the Twenty-First Century 22 (2001). Particularly damning for theories that target black communities as uniquely pathological, researchers have demonstrated that poor whites exhibit the same "deviant" behaviors as African-Americans. See Yvette Alex-Assenoh, Myths About Race and the Underclass: Concentrated Poverty and "Underclass" Behaviors, 31 URB. AfF. Rev. 3-17 (1995).

123. See Katz, The Price of Citizenship, supra note 116, at 320 ("In the welfare debates of the 1990s, conservative accounts of research simply misrepresented the evidence.").

124. See Kost \& Munger, supra note 62, at 33 (arguing that the culture of poverty thesis has been widely accepted because it "satisfies so many political and ideological needs").

125. See id. at 66-72; ICELAND, supra note 108, at 77-78. See also Handler, supra note 111, at 10-12; KATZ, supra note 112, at 77-78. 
William Julius Wilson explains concentrated urban poverty among AfricanAmericans by pointing to the transformation of the urban economy that moved high-paying jobs for manual workers out of the inner-cities, leaving only lowpaid service jobs behind and a growing nonworking class of black men. ${ }^{126}$ High unemployment rates among black men led to low marriage rates and concurrent increases in single motherhood. These economic shifts also created an outward movement of middle-class blacks from ghetto neighborhoods, with an accompanying loss of role models, contacts to mainstream society, and linkages to employment opportunities. Of course, personal behavior and bad personal choices also contribute to poverty, but "it is difficult to find behavior that is not somehow related to the inherited conditions of being poorly parented, poorly educated, poorly housed in neighborhoods from which no distant horizon of possibility can be seen."127 As Wilson explains, negative cultural attitudes associated with poverty result from a lack of opportunity, they do not create it. ${ }^{128}$

Concentrated poverty among inner-city African-Americans not only results from economic shifts over the last thirty years, but is also the direct result of governmental policies that served to isolate and segregate these communities from the rest of the urban and regional environment, as Douglas Massey and Nancy Denton have shown. ${ }^{129}$ Following World War II, the white middle-class left the inner cities for suburban homes subsidized by federallyunderwritten mortgages and on highways built with federal funds. ${ }^{130}$ African-

126. William Julius Wilson, The Truly Disadvantaged: The Inner City, the Underclass, ANd Public Policy 29-62 (1990).

127. David K. Shipler, The Working Poor 7 (2004). Shipler notes, "The poor have less control than the affluent over their private decisions, less insulation from the cold machinery of government, less agility to navigate around the pitfalls of a frenetic world driven by technology and competition." Id.

128. See Wilson, supra note 121, at 181-82. See also ICELAND, supra note 108, at 96 (evaluating poverty research and concluding that "[e]ven among people who have been poor for a long time and, moreover, live in high poverty areas, differences are likely less rooted in aberrant values and more a result of functional adaptations to a difficult environment").

129. See Douglas S. Massey \& Nancy A. Denton, American Apartheid: Segregation and the Making of the Under Class 148-49 (1998). See also Alice O'Connor, Historical Perspectives on Race and Community Revitalization, at $\mathrm{http}$ ://www.aspeninstitute.org/Program1. asp?bid=1251 (last visited Apr. 5, 2005) ("“ $[\mathrm{H}]$ istory, with its central concern for human agency, shows unequivocably that there is nothing 'natural' or inevitable about the racialized 'pockets' of concentrated poverty that have become an accepted part of the urban - and rural-United States."). Massey and Denton argue for dismantling the ghettos through integrationist policies. MASSEY \& DENTON, supra at 225-26. For a critique of their approach, see John O. Calmore, Racialized Space and the Culture of Segregation: "Hewing a Stone of Hope From a Mountain of Despair," 143 U. PA. L. REv. 1233, 1245 (1995) (arguing that the culture of segregation thesis is a variation on the culture of poverty thesis that perpetuates stereotypes of the poor).

130. See Massey \& Denton, supra note 129, at 44. "As poor blacks from the south entered cities in large numbers, middle-class whites fled to the suburbs to escape them and to insulate themselves from 
Americans were trapped within inner-cities when the federal government and private banks redlined minority neighborhoods and refused to provide them with mortgages. ${ }^{131}$ Moreover, the location of the highways destroyed many viable low-income communities, and created physical barriers within cities that separated poor neighborhoods from central business districts. ${ }^{132}$ In turn, the suburbs used zoning and other exclusionary policies, such as restrictive deeds, to keep out blacks and other minorities.

These segregated housing patterns were then reinforced by urban renewal in the 1950s and 1960s, which compounded the isolation of poor blacks by clearing slum neighborhoods in the cities to make way for redevelopment of central business districts. ${ }^{133}$ Displaced blacks were forced into new, highdensity public housing projects situated in already crowded black neighborhoods, which became further destabilized. ${ }^{134}$ The problems of the ghetto intensified in the 1970 s, despite the civil rights movement and rising incomes among black workers, due to subtle (and ongoing) forms of racial discrimination in which "blacks [were] systematically shown, recommended, and invited to inspect many fewer homes than comparably qualified whites." 135 Under the Reagan and Bush Administrations, the federal government "stopped building housing, shrank its aid to cities, reduced benefits to individuals, and raised the taxes of the poor at the same time it lowered them for the rich."136 Currently, urban development is focused on office buildings, convention centers, sports arenas, and festival marketplaces, the effects of which have not trickled down to less-fortunate neighborhoods. As a result of these and other government policies and economic shifts, onefifth of blacks live under conditions of intense racial segregation, ${ }^{137}$ making

the social problems that accompanied the rising tide of poor." Id. at 55. See also WiLSON, supra note 121, at 46 ("Bymanipulating market incentives, the federal government drew middle-class whites to the suburbs and, in effect, trapped blacks in the inner cities.").

131. See MASSEy \& Denton, supra note 129, at 50-52. As a result, property owners in the inner cities could not sell their properties, which declined in value and led to a "pattern of disrepair, deterioration, vacancy, and abandonment." Id. at 55 .

132. See Wilson, supra note 121, at 47; Michael Katz, Reframing the Underclass Debate, in ANEW Introduction to Poverty: The Role of Race, Power, and Politics, supra note 114, at 68-69.

133. See Katz, supra note 132, at 68.

134. See Massey \& Denton, supra note 129 , at 55-56.

135. See id. at 104; see also id. at 60-82,98-100. "Although each individual act of discrimination may be small and subtle, together they have a powerful cumulative effect in lowering the probability of black entry into white neighborhoods." Id. at 98.

136. Katz, supra note 132, at 69.

137. See Paul A. Jargowsky, Stunning Progress, Hidden Problems: The Dramatic Decline of Concentrated Poverty in the 1990s, The Brookings Institution, May 2003, at www.brookings.edu/es/urban/publications/jargowskypoverty.pdf. In the 1990s, the number of African- 
them "unambiguously among the nation's most spatially isolated and geographically secluded people." ${ }^{\prime 18}$ This history highlights the unfairness, and indeed the futility, of the TANF's emphasis on self-help strategies to alleviate poverty. At the same time, the culture of poverty thesis that undergirds TANF ignores the immense resources and resiliency of "underclass" communities in the face of severe economic deprivation. ${ }^{139}$ Thus, not only are these communities denied a richer, more accurate portrayal in the face of demeaning stereotypes, but they are also denied anti-poverty strategies that respond to the realities of urban life.

Because communitarian thinkers have not scrutinized poverty or racism, their rhetoric has been appropriated without an assessment of whether the rhetoric matches the reality. The reality is that TANF not only ignores economics, but it also overlooks the ways that parents are bound by obligations to, and the dependencies of, their children. "It also neglects the importance, the reality, and the necessity of wider social ties and connections. It makes invisible, in other words, our interdependence." 140 Yet this is exactly the terrain that communitarians claim to tread. In a sense, we have gotten the worst communitarianism has to offer, without its potential best. However, it is not simply politicians who are to blame. Communitarians have failed to engage the issue of poverty and have articulated only a "thin" conception of community that provides little foundation for moving beyond individual blame in dealing with the poor.

\section{The Limits of Communitarianism}

Communitarians tend to be united against liberal methodology and the fragmentation they contend that liberalism has had on Western society. Nevertheless, many communitarians have been vague about their own specific normative vision of society. It is hard to assess a political theory that focuses largely on attack, without proffering an alternative vision. However, two American political philosophers long-identified with communitarianism,

Americans living in concentrated poverty neighborhoods (defined as census tracts where over forty percent of residents are below the poverty line) dropped by one-third after two decades of staggeringly high increases. $I d$. However, inner-ring suburbs experienced increases in poverty. Id. Moreover, the recession of the early 2000 s, accompanied by increases in unemployment and a rise in the poverty rate, may be countering this trend. Id.; see also William Julius Wilson, editorial, There Goes the Neighborhood, N.Y. Times, June 16, 2003, at A19.

138. See MAssey \& Denton, supra note 129 , at 77.

139. See infra Part III.

140. HAYs, supra note 68, at 216. 
Michael Walzer and Michael Sandel, have made a considerable effort to define the precise nature of the "good" that they believe we should pursue - and their views diverge. Walzer advances an egalitarian view of justice that looks to internal, shared values for distributing social goods, while Sandel promotes a revival of the civil republican strand in American politics and law. More than other communitarian thinkers, they have addressed the challenges posed by the vast inequalities that mark our society and come to different conclusions than Rawls. Accordingly, this Article proceeds to assess the lessons that can be learned from, and the criticisms that can be leveled at, Walzer and Sandel in shaping our social welfare policies and jurisprudence. In addition, the following section analyzes the more overtly political wing of communitarianism, which has a more sociological perspective and whose principal proponent is Amitai Etzioni. Etzioni aims to fashion public policies that solve societal problems by balancing individual rights with communal norms, and he provides a lengthy list of policy prescriptions for achieving this balance.

\section{A. Michael Sandel}

Michael Sandel rejects the individualized concept of personhood espoused by John Rawls, which he contends is reflected in our constitutional jurisprudence and our political economy. The result is our "procedural republic" that prioritizes rights over values and that has led to a widespread malaise and dissatisfaction among Americans. Accordingly, he urges a return to civic republicanism, in which liberty is fostered through self-government, as a corrective for the failures of the procedural republic. ${ }^{141}$ Sandel's insights about personhood and participatory politics hold particular promise for combating poverty. Because he situates individuals within their communities, and because he stresses the involuntary nature of those connections, he provides a theoretical foundation for moving away from the "culture of poverty" thesis towards the empirically accurate proposition that poverty is caused by complex structural and demographic forces that need to be reformed if we are going to reduce poverty. If individuals do not choose to be poor, then we are forced to ask how they become poor. In addition, Sandel's

141. In Liberalism and the Limits of Justice, Sandel presented a sustained and sophisticated philosophical case against Rawlsian liberalism. SANDEL, Liberalism, supra note 13. In the subsequent Democracy's Discontent, he used law and the history of political economy to explain the rise of our rightsbased culture and to recommend a civic republican alternative. Sandel, Democracy's Discontent, supra note 2 . 
emphasis on civic republicanism supports a revitalized emphasis on community participation in public policies that affect and shape poor communities. That is, if we want disenfranchised and disempowered persons to participate in politics - indeed, to see participation as worthwhile-we will need to not only make radical changes to our political system that decrease the role of money in electoral politics, but also to our social safety net, so that all people have the skills and resources to be active citizens. Sandel's theories could thus move poverty policies away from blaming the victim and away from the very idea of "victimhood" itself. Unfortunately, Sandel never makes these moves. Rather, he places the blame for the procedural republic on the rise of the welfare state, thus misconceiving the extent of "rights" discourse within poor communities, overstating the impact of the welfare state on middle-class mores, and revealing his own fixation with middle-class concerns. Indeed, he seems willing to leave current economic structures in place, and his policy prescriptions ignore the barriers to meaningful civic participation that exist in poor communities.

\section{Sandel's Attack on the Procedural Republic}

Sandel accuses Rawls of viewing community as the mere cooperation of mutually disinterested individuals, rather than as the foundation of identity and moral judgment. Although Rawls endorses communitarian ideals as one of the many possible individual aims, it is only "one contender among others." ${ }^{142}$ This is not enough for Sandel, because it separates the self from its interests. The Rawlsian person is "wholly without character, without moral depth," ${ }^{143}$ and does not describe how we experience life. Under liberal theory, "[n] o commitment could grip me so deeply that I could not understand myself without it. No transformation of life purposes and plans could be so unsettling as to disrupt the contours of my identity." " 144 By contrast, according to Sandel, "[C]ommunity . . . describe[s] not just a feeling but a mode of selfunderstanding partly constitutive of the agent's identity."145 Whereas Rawls views rights as a means for promoting government neutrality, Sandel asserts that "rights [should] depend for their justification on the moral importance of

142. SANDEL, Liberalism, supra note 13 , at $61,64$.

143. Id. at 179 .

144. Id. at 62 .

145. Id. at 150 . 
the ends they serve." ${ }^{146}$ For Sandel, Rawlsian theory accurately describes our modern state.

Sandel contends that we are a discontented nation due to an increasing disenchantment with governmental affairs and the concomitant breakdown of community values. He traces these dual disintegrations to the rise of the "procedural republic," a philosophy defined by "the priority of individual rights, the ideal of neutrality, and the conception of persons as freely choosing, unencumbered selves." ${ }^{147}$ According to Sandel, the liberal view that government should be neutral as to the ends its citizens pursue has led us to value fair procedures over particular values. ${ }^{148}$ In our procedural republic, government does not endorse any particular conception of the good life or attempt to inculcate particular value in its citizens; instead, it allows for a plurality of views and ensures that people have opportunities and space within which to exercise their choices. While the procedural republic encourages social cooperation, it also denies competing values that arise from moral and religious convictions and discourages the cultivation of the qualities that lead to self-rule. ${ }^{149}$ Sandel places the blame for the rise of the procedural republic on the Supreme Court and on the pre-TANF welfare state that arose after the New Deal, and he contrasts the late twentieth century state of affairs to a longhistorical tradition of civic republicanism in both our jurisprudence and political economy. ${ }^{150}$

\section{a. The Supreme Court and the Procedural Republic}

Sandel accuses the Supreme Court of defining and protecting individual rights without endorsing any particular view of the good life, thereby leading to value-neutral politics that discourage civic virtue. ${ }^{151}$ He claims, however, that this is a relatively recent way of viewing rights and one not foreseen by the nation's Founders. Indeed, for the first one hundred years, "the Bill of Rights [did not] play an important role in protecting individual liberties against federal infringement"; rather, liberty was seen as derived from the "dispersion of power among branches and levels of government."152

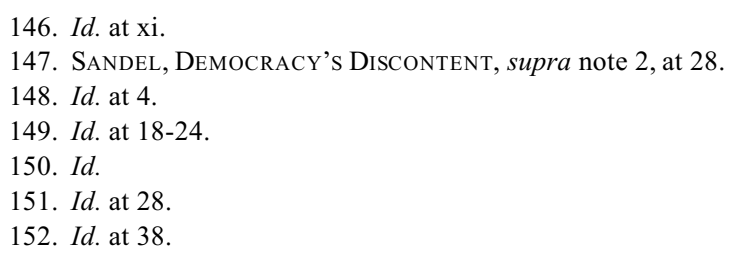


Following the Civil War, the Court applied the Fourteenth Amendment to the states and began to assume its role as protector of individual rights. Sandel points to the Court's decision in Lochner v. New York ${ }^{153}$ as a turning point, because the Court emphasized the individual right to contract freely over other substantive values, such as protecting workers. ${ }^{154}$ Eventually, the procedural republic triumphed in the 1943 case of West Virginia $v$. Barnette, ${ }^{155}$ when the Supreme Court struck down a compulsory Pledge of Allegiance requirement only three years after upholding a similar requirement. To Sandel's chagrin, the Court in Barnette emphasized patriotism as a matter of choice instead of as a civic virtue. ${ }^{156}$

In critiquing the Supreme Court's jurisprudence, Sandel focuses on religious liberty, free speech, privacy, and family law. In each of these categories, he asserts that the Supreme Court wrongly demands that government remain neutral on questions of values in order to foster personal autonomy. ${ }^{157}$ In other words, the Court demands that citizens bracket their moral identities from political discourse in order to secure social cooperation. ${ }^{158}$ For instance, Sandel explains that in religion clause cases, the neutrality approach results in respect for individuality, but not for the value of religion. ${ }^{159}$ Under Court doctrine, the military can ban the wearing of yarmulkes and the state can deny special protection for the sacramental use of Peyote, because religious beliefs carry no more weight than mere preferences, and such preferences cannot justify special exemptions from generally applicable statutes. ${ }^{160}$ By contrast, Sandel views religion as a stimulant for self-government; it has the ability "to promote the habits and dispositions that make good citizens." 161 Because religious beliefs are not always chosen, but are often viewed by their bearer as an essential part of their self-identity, asking individuals to bracket these beliefs may "frustrate them more profoundly than to deprive them of interests less central to the projects that

153. Lochner v. New York, 198 U.S. 45 (1905).

154. SANDEL, DemOCRACY's Discontent, supra note 2, at 41-42.

155. West Virginia v. Barnette, 319 U.S. 624 (1943).

156. Sandel, Democracy's Discontent, supra note 2, at 53-54.

157. See id. at 90,100 .

158. SANDEL, Liberalism, supra note 13, at 196.

159. SAndel, Democracy's Discontent, supra note 2, at 71. The precise meaning of "neutrality" is ever-shifting. See Mitchell v. Helms, 530 U.S. 793, 878 (2000) (Souter, J., dissenting) (“"Neutrality' has been employed as a term to describe the requisite state of government equipoise between the forbidden encouragement and discouragement of religion; to characterize a benefit or aid as secular; and to indicate evenhandedness in distributing it.").

160. SANDEL, DEMOCRACY's Discontent, supra note 2, at 69-70.

161. Id. at 66 . 
give meaning to their lives." 162 By focusing on autonomy, Sandel says, the Court misses not only the opportunity to foster civil republicanism, but it also loses sight of the fact that the Constitution singles out religion - and not other beliefs - for protection. For Sandel, the Court "fail[s] to take religion seriously." "163

Sandel asserts that the Court's failure to respect persons as encumbered by involuntary connections undermines the possibilities for self-government. As he explains, the Court simply does not value the communal attachments that cultivate political education, such as the ties that arise from family, neighborhoods, unions, and local government. ${ }^{164}$ Further, the Court's emphasis on autonomy in the private sphere is ill-fitted for the complex web of dependencies that mark and control the public sphere of modern life. In other words, the expansion of government through regulation and the dominance of large corporations have eviscerated the centrality of the individual in economic life, making autonomy almost meaningless. ${ }^{165}$ At the same time, Sandel charges that we are quick to demand entitlements and rights in the public sphere without any corresponding sense of mutual responsibility and moral engagement. ${ }^{166}$

\section{b. The Welfare State and the Rise of the Procedural Republic}

Sandel criticizes not only our jurisprudence, but also our political economy. For Sandel, the procedural republic stretches far beyond the Supreme Court and into every social and political aspect of American life. Through a detailed historical analysis, Sandel asserts that throughout most of our country's past, economic decisions were debated and decided with regard to whether or not they were hospitable to self-government. ${ }^{167}$ Now, he claims, we ask only whether a given policy is fair and likely to engender prosperity. Sandel claims that only in the latter part of the twentieth century did our philosophy demand that government be neutral as to values; previously, it was deemed appropriate for government to shape the moral and civil character of

162. Sandel, Liberalism, supra note 13, at xiii; see also Sandel, Democracy's Discontent, supra note 2, at 67.

163. SANDEL, Democracy's Discontent, supra note 2, at 71.

164. See id. at 117.

165. See id. at 118 .

166. Id. at 119 .

167. Id. at 124 
its citizens. ${ }^{168}$ He traces the demise of civic republicanism to the growth of the American welfare state. ${ }^{169}$

For instance, he explains that President Franklin Delano Roosevelt set forth a New Deal agenda that sought to secure economic rights, such as "the right to a useful and remunerative job" and the "right to earn enough to provide adequate food and clothing and recreation," based on the idea that "necessitous men are not free men." Poverty, President Johnson promoted abundance, rather than the inculcation of moral virtues in citizens. Indeed, to make the case for fighting poverty, Johnson urged Americans to rise above class, race, and religion-aspects of the self that cannot be cleaved from us, according to Sandel. ${ }^{171}$ Sandel speaks disapprovingly of welfare advocates who fought successfully in the 1960s and 1970s to remove moral judgments from public assistance programs, because they fostered a neutral, rights-based mentality on the part of welfare recipients, the government, and the rest of the American public. ${ }^{172}$

\section{c. Repairing the Procedural Republic}

Sandel claims that we pay a steep price for the neutrality of the procedural republic, noting that we have become isolated from our larger surroundings and feel powerlessness over our lives. Our politics lack moral resonance, leaving a vacuum that is filled by shallow and intolerant groups that impose their moralisms on others. ${ }^{173}$ Sandel charges that liberalism's emphasis on plurality and diversity provides no answer to these conservative, moralistic groups. Accordingly, Sandel advocates for the revival of civic republicanism. For Sandel, republicanism is the "good." He envisions fellow citizens who deliberate about the common good and share in shaping their own destinies. ${ }^{174}$ To Sandel, freedom comes not from choice and autonomy, but from self-government. Thus, instead of putting the right before the good, Sandel advocates for putting the common good before individual rights. ${ }^{175}$ Politics and other civil institutions must cultivate the qualities of character that

168. Id. at 201.

169. See SAndel, Democracy's Discontent, supra note 2, at 280.

170. Id. at 281.

171. See id. at 282.

172. See id. at 118-19,286-88.

173. Id. at 332 .

174. Id. at 5 .

175. Id. at 25 . 
foster self-government. ${ }^{176}$ He urges emphasis on mediating institutions such as "townships, schools, religions, and virtue-sustaining occupations that form the 'character of mind' and 'habits of the heart' a democratic republic requires." ${ }^{\prime 17}$ Recognizing that republicanism is rife with possibilities for coercion and paternalism, Sandel stresses the need for dispersed power and multiple sites of civic formation. ${ }^{178}$

\section{A Critical Assessment of Sandel}

Sandel's descriptive and normative visions have been thoughtfully and thoroughly critiqued and assessed by a wide variety of scholars. ${ }^{179}$ Accordingly, this Article focuses solely on how Sandel's theories relate to conditions of, and remedies for, poverty, an approach not taken by Sandel's other critics. ${ }^{180}$ It concludes that Sandel has much to offer in thinking about poverty, but that he misunderstands the causes of poverty and thereby reinforces negative stereotypes of the poor.

\section{a. Sandel's Communities and Poor Communities}

Sandel's critique of the atomistic individual resonates in poor communities, where economic deprivation grossly limits one's ability to define and achieve chosen ends. By shifting the focus from the individual to community, Sandel's critique could challenge TANF's underlying assumption that poverty results from character deficiencies of the poor. Sandel himself does not make this move, but it is the logical endpoint of his brand of communitarianism. Given that people are shaped by involuntary connections to their families, community, religion, and the like, it is mistaken to conclude that people freely choose their place in society. To the contrary, persons born without economic and social resources are often doomed to exercise limited autonomy within a constrained sphere. ${ }^{181}$ Of course, the poor make choices

176. Id. at 6,79 .

177. Id. at $320-21$.

178. Id. at 321

179. See, e.g., Debating Democracy's Discontent, supra note 41.

180. Joan Williams is one exception. In Debating Democracy's Discontent, she attempts to strengthen Sandel's republicanism in order to combat income inequality. She proposes linking republicanism to religious rhetoric and rhetoric surrounding family values. Joan Williams, Notes of a Jewish Episcopalian: Gender as a Language of Class; Religion as a Dialect of Liberalism, in DeBATING Democracy's Discontent, supra note 41, at 99.

181. "Members of racial-ethnic minority groups disproportionately face an urban opportunity 
every day; some are wiser than others. Yet, for the poor, constraints on autonomy arise from "segregated housing; lack of positive role models as neighbors; limitations on capital; inferior public services; lower quality public education; more violent, drug-infested neighborhoods; and impaired access to employment and job-related information networks" as well as discrimination, which tends "to lock minorities into particular spatial niches." 182 TANF is a response to stereotypes generated about the urban underclass, but membership in this the so-called underclass is not a matter of choice. "Where one lives - especially, where one grows up - exerts a profound effect on one's life chances." 183 As Douglas Massey and Nancy Denton explain, in a manner that reinforces the communitarian notion of socially encumbered individuals:

Identical individuals with similar family backgrounds and personal characteristics will lead very different lives and achieve different rates of socioeconomic success depending on where they reside. Because racial segregation confines blacks to a circumscribed and disadvantaged niche in the urban spatial order, it has profound consequences for individual and family well-being. ${ }^{184}$

Thus, Sandel's notion of the socially constituted individual accurately captures one problem with liberal theory for the poor. Liberalism presumes that everyone can leave behind their existing communities and choose new ones. Yet, the poor are almost forcibly communitarian; they typically lack the resources to simply pick up and move on.

Despite constraints on individual autonomy, blacks in poor communities have demonstrated immense resiliency and resources in situations of extreme economic deprivation through interdependent networks of support and

structure that substantially constrains their mobility across socioeconomic strata." George C. Galster, Polarization, Place, and Race, 71 N.C. L. Rev. 1421, 1429 (1993). Sharon Hays points out that the American belief in a meritocracy

stands in sharp contrast to the proposition that where people end up is a matter of fate, luck, accidental coincidence, and the socially structured position into which they were born. In examining the lives of these welfare mothers, however, it appears that fate, bad luck, unforeseeable setbacks and, above all, the position into which they were born have been a good deal more important than hard work and dedication in determining their success.

HAYs, supra note 68, at 176.

182. See Galster, supra note 181 , at 1429-30.

183. See MAssey \& Denton, supra note 129, at 149.

184. See id.; see also Kenneth Karst, Law, Cultural Conflict, and the Socialization of Children, 91 CAL. L. REv. 967, 1018-19 (2003). Karst charges that conservative moralists "would impose so-called middle class values on young people whose day-to-day experience provides little or no sense of opportunity, little or no reason to believe in the utility of schooling, or of life-planning, or, indeed, of anything that involves deferred gratification. In short, these young people live in circumstances that lack the necessary foundations for inculcating the so-called middle class behavior that the moralists prize." Id. 
sustenance. ${ }^{185}$ Thus, Sandel's emphasis on community as a locus of moral values could serve to highlight the social capital inherent in so-called underclass neighborhoods and to create a richer, less-stereotyped vision of life in those neighborhoods. Further, Sandel correctly asserts that civic participation can counter disempowerment, and numerous studies have identified community participation as a necessary component of anti-poverty initiatives in distressed neighborhoods. Sandel's description of socially constituted personhood thus captures the degree to which communities can foster dignity, self-worth, and even autonomy.

To be fair, liberalism also contains a strand for resisting the "undeserving" characterization of the poor. Rawls argues that people do not have a claim to the economic status they are born into or even their personal social endowments, such as intelligence or musical talent, and that these attributes are therefore common assets that should be shared with the lessfortunate. ${ }^{186}$ The Rawlsian perspective assumes a clear line of demarcation between advantage and disadvantage and presumes little worth in situations marked by deprivation. This division tends to pit the haves against the havenots in a tug-of-war for assets. Not surprisingly then, a major critique of Rawls within the liberal tradition has been made by philosophers such as Robert Nozick, who argues against redistribution on the basis that "past circumstances or actions ... can create differential entitlements or differential deserts to things." 187 By contrast, Sandel's perspective holds out hope for viewing equality as something more than a zero sum game. If people are shaped by the involuntary circumstances into which they are born, it makes sense to improve those circumstances for the benefit of the entire society and to appeal to a broader communal ethic for aiding economically deprived communities. Sandel, however, does not make such an argument, even though reducing poverty could dramatically increase civic participation within longdisempowered communities. He simply does not see, or chooses to ignore, the effects of poverty upon his policy prescriptions.

\section{b. Barriers to Public Participation in Poor Communities}

Despite Sandel's commitment to pursuing moral ends, he never links eradication of poverty with its possibilities for enhancing civic participation.

185. See infra Part III.

186. See supra notes $20-25$ and accompanying text.

187. NozICK, supra note 7, at 155. 
This is not to say that Sandel is indifferent to the plight of the poor. He plainly seeks to include them within his renewed civic republicanism and he favors initiatives such as community development corporations that give voice to inner-city residents. He is particularly concerned about the increasing gap between the rich and poor, but not because growing inequality causes suffering. Rather, for Sandel, "inequality undermines freedom by corrupting the character of both rich and poor and destroying the commonality necessary to self-government." 188 Sandel identifies the ongoing withdrawal of affluent Americans from public life, as they purchase their own security, send their children to private schools and private parks, and move to private, guarded communities, and he thus advocates for a renewed commitment to public, civic spaces of social contact. ${ }^{189}$ His solution focuses on bringing the affluent back into public life through institutions such as public libraries and parks. As a practical matter, given the segregation of minority neighborhoods, it would be hard to find cross-racial and cross-class meeting places without massive governmental programs to support integration. Yet communitarians do not call for integrationist strategies; their focus on communities suggests place-based remedies for poverty and segregation. Sandel does not suggest that civic republicanism will abolish inequality, but only that it will " "strengthen[] community institutions in which income is irrelevant.", 190 Under Sandel's proposals, even with massive social spending on public sites that foster community life, the poor would still be poor - they would just have more opportunities to mingle with the affluent. ${ }^{191}$ At that point, it is likely that the perspectives of the affluent would dominate.

\section{c. The Dangers of Majoritarianism}

Sandel does not fully respond to the dangers of majoritarianism that can lurk within "community." He defines community at multiple levels, from family all the way to the nation state. This flexibility allows him to support communities that are sympathetic to civic republican ideals, ${ }^{192}$ but does not

188. Sandel, Democracy's Discontent, supra note 2, at 330.

189. Id. at 332 .

190. Id. at 333 .

191. For this reason, Joan Williams argues that for civic republicanism to alter conditions of inequality it will have to embrace arguments "that enable the working poor and working class to claim domesticity's middle-class ideals of family life, and arguments (in either religious or secularized variants) that insist that the poor are our poor, that property rights should be limited where they present a threat to human dignity." Williams, supra note 180, at 113.

192. For instance, Sandel has defended homosexuality, the achievements of the civil rights 
provide a resounding response to communities that marginalize certain members. TANF demonstrates this tension. Much of TANF is built upon appeals to community values, in particular, its emphasis on work and behavioral modification. Sandel seems sympathetic to these sorts of requirements, ${ }^{193}$ probably because work and family seem central to those qualities of character that foster self-government. But, Sandel does not consider that some jobs and some families are unlikely sites for fostering civic virtue and political participation. While TANF appeals to community values, it does not promote mechanisms that would actually strengthen communities. For instance, it requires work, but does not provide the supports necessary to move people toward self-sufficiency, such as a living wage, child care, transportation, and the like. It thus sets the poor up for failure and serves to further isolate them from the mainstream, by allowing society to blame those low-income individuals who fail to achieve the supposed self-sufficiency offered to them by TANF.

Not surprisingly, in the nine years since welfare was reformed, there has been no groundswell of civic participation by the poor. To the contrary, TANF appears to be diluting attempts at grassroots organizing among the poor. ${ }^{194}$ This lack of political activity is not surprising, given that the majority of welfare leavers remain in low-paid, demeaning jobs that trap them below the poverty line as they strain to feed and house their families. People who work multiple jobs or jobs at irregular hours and who struggle to obtain transportation and childcare not only lack the mental and physical wherewithal to spend additional hours on matters of public governance, but often also perceive political participation as futile. The political agenda and priorities of elected officials rarely intersect with the interests of the poor. ${ }^{195}$ Dorothy Roberts points to "evidence that poverty, social isolation, and inadequate

movement, the regulation of pornography by local communities, and laws that regulate plant closings in order to protect the local community. Simon, supra note 8, at 114. "So, Sandel's communitarianism shows notable concern for the disadvantaged: African Americans, women, homosexuals, and workers." Id. But, "[i]n the hands of a communitarian less sympathetic to the plight of the disadvantaged," they might lose these protections. Id.

193. See Sandel, Democracy's Discontent, supra note 2, at 325-28 (speaking approvingly of the debates surrounding welfare reform).

194. See James Jennings, Welfare Reform and the Revitalization of Inner City NeIGHBorhoods 69-82 (2003).

195. See Ann M. Burkhart, The Constitutional Underpinnings of Homelessness, 40 Hous. L. REv. 211,276 (2003) ("Aside from voter registration and other structural obstacles to voting is the lower class's sense of political powerlessness."). The sense of political powerlessness is also driven by the role of money in campaign financing and the dominance of special interests. See infra notes 253-57 and accompanying text. 
education reduce levels of political participation."196 This observation does not negate the fact that many poor communities have long been sites of political resistance (as opposed to participation), where members have fought to shape and better their environments despite overwhelming odds. Yet, they did so without the specter of work or behavioral requirements contained in welfare statutes. They attempted self-governance because of their shared history of oppression and a desire to foster community solidarity.

A prime example is the civil rights movement of the 1950s and 1960s, which Sandel points to as the single example of civic republicanism in the wasteland of the procedural republic. ${ }^{197}$ Although the ultimate aim and result of the civil rights struggle was to secure individual rights against prejudice and to promote the freedom to choose one's ends, it was also a communitarian "moment of empowerment" that turned ordinary individuals into agents of change and that "displayed a higher, republican freedom - the freedom that consists in acting collectively to shape the public world." 198 Black southern churches were the sites of civic activity that made the movement possible, by allowing for meetings, education, and prayer. ${ }^{199}$ Interestingly, Sandel draws no connection between the civil rights movement and the welfare rights movement that secured rights to fair administration of welfare benefits. ${ }^{200}$ To the contrary, he blames the welfare state - and those who expanded it — for the malaise he diagnoses in American society.

196. See Dorothy Roberts, The Moral Exclusivity of the New Civil Society, 75 CHI.-Kent L. Rev. 555, 561-62 (2000). She discusses a Detroit survey of inner-city blacks that found "that those living in poor neighborhoods were less likely to engage in civic activities, belong to a church, attend community meetings, or contribute money to political candidates." Id.

197. SANDEL, DEMOCRACY's Discontent, supra note 2, at 348.

198. $I d$.

199. Id. at 349. Black churches are playing a key role in implementation of TANF's charitable choice provision, which authorizes government funding for religiously based social services. See Gilman, Charitable Choice, supra note 78, at 806-14 (describing charitable choice); Gretchen M. Griener, Charitable Choice and Welfare Reform: Collaboration Between State and Local Governments and FaithBased Organizations, Welfare Information Network, Sept. 2000, at http://www.financeprojectinfo.org/ Publications/issuenotcharitablechoice.htm (summarizing studies that have found black churches more interested in faith-based partnerships than other churches). Sandel would certainly approve of the faithbased anti-poverty strategy because it brings people into a site of civic virtue.

200. But see Martha F. Davis, Brutal Need: Lawyers and the Welfare Rights Movement, 1960-1973, at 120 (1993); Mimi Abramovitz, Fighting Back: From the Legislature to the Academy to the Streets, in A New Introduction to Poverty, supra note 114, at 217, 227-29; William E. Forbath, Constitutional Welfare Rights: A History, Critique, and Reconstruction, 69 FordHAM L. Rev. 1821, 1845-55 (2001). 


\section{d. The Welfare State and Rights Discourse}

Sandel goes too far in blaming the welfare state for widespread societal dissatisfaction, especially given the isolation of the urban poor from mainstream society. His attack on the welfare state looks disconcertingly like the tired rhetorical ploy of blaming the poor for society's problems. ${ }^{201}$ After all, little of the case law that developed from the welfare rights movement accrued to the benefit of the middle-class; they already had property rights. Moreover, Sandel overstates the generosity of the welfare state. There is no "right" to welfare benefits; all that welfare advocates in the 1960s and 1970s were ultimately able to procure were rights to fair procedures in the distribution and administration of legislatively granted benefits. Those benefits were (and continue to be) small in amount and far less than what is needed to obtain self-sufficiency. It is difficult to see, and Sandel does not explain, how these limited welfare rights created an entire nation beset by an entitlement mentality. Moreover, John Gilliom's study of welfare recipients' interactions with welfare bureaucracies revealed that recipients engaged in strikingly little "rights talk," instead discussing privacy invasions by the welfare state through a rhetoric of care. ${ }^{202}$ Gilliom concludes that the poor do not fixate on "rights" as do more affluent Americans. ${ }^{203}$

While Sandel is concerned about malaise, it is really the malaise of the middle-class that he is discussing. ${ }^{204}$ In the daily scramble to meet basic needs, the poor do not have the luxury for such melancholy musings. As Mark Tushnet points out, Sandel is appealing to people with economic security. For instance, Sandel highlights the picketing of Wal-Mart as a prime example of communitarianism virtue. Yet, "that is the sort of thing that can be said, or at

201. Dorothy Roberts points out that civil society revivalists, whose normative vision is similar to that of Sandel's, often link moral decay with advances in social justice. "Civil society revivalists count declines in morality and social capital as a cost exacted by improvements in economic and social equality. They tend to balance advances made by women and minorities against the social harms caused by civic disengagement and moral disorder." Roberts, supra note 196, at 569.

202. John Gilliom, Overseers of the Poor: Surveillance, Resistance, and the Limits of PRIVACY 15 (2001).

203. See id. at 92.

204. Mark Tushnet contends that Democracy's Discontent "responds to the discontent of today's professional-managerial class faced with reduced autonomy as corporate capitalism increasingly limits the domain in which professionals can exercise professional judgment and discretion." Mark Tushnet, A Public Philosophy for the Professional-Managerial Class, in DeBATING Democracy's Discontent, supra note 41 , at 92 . He asserts that Sandel fails to address the "real source" of discontent among the professionalmanagerial class - "the ... uncontrollable power of transnational corporations." Id. at 93. 
least admired, only by people who do not have to worry that higher-priced underwear means sending their children to school in worn-out underwear or having less food on the table for dinner." ${ }^{205}$ The value of civic republicanism for the poor is not that it will cure malaise, but that it opens opportunities for the poor to shape their environments and to make demands upon government for a greater share of society's resources.

\section{e. The Procedural Republic and the Poor}

The procedural republic, as reflected in the pre-1996 welfare system, was a mixed blessing for the poor. On one hand, AFDC provided needed material assistance to the poor, although the assistance was generally stingy and insufficient. Most people used welfare as an intermittent safety net, not as a way of life, and it helped them survive temporary setbacks such as the loss of a job, a divorce, or the illness of a child. Welfare advocates, using the tools of the procedural republic, eventually removed moral judgments from welfare delivery and obtained legal protections (if not actual protections) against unfair and arbitrary administration-achievements that recognized and enforced the individual dignity of recipients. On the other hand, AFDC never significantly decreased poverty; it impeded the accrual of assets and constrained the formation of two-parent families. ${ }^{206}$ Moreover, the legal gains made by welfare advocates helped to foster the backlash against the poor, who were charged with taking from society's till without giving anything back. Yet, the welfare state truly failed not because it did not demand enough of the poor, but because it did not demand enough of society. Likewise, TANF's notion of reciprocity is a one-way street. It requires welfare recipients to work, but does not reciprocate by ensuring that jobs are available in the economy, that jobs pay a living wage, or that work be compatible with family obligations. In this way, Sandel's critique of the welfare state seems to miss the mark.

205. $I d$.

206. See Raymond H. Brescia et al., Who's In Charge, Anyway? A Proposal for Community-Based Legal Services, 25 Fordham URB. L.J. 831, 850-55 (1998). Brescia notes that despite the gains of the individual rights approach to battling poverty, "the plight of poor clients is as bad as or worse now than at any time during the twenty-five years that legal services programs have been in existence." Id. at 852 (quoting Paul E. Lee \& Mary M. Lee, Reflections from the Bottom of the Well: Racial Bias in the Provision of Legal Services to the Poor, 27 Clearinghouse Rev. 311, 312 (1993)). 


\section{f. The Supreme Court and the Morals of the Poor}

Sandel complains that the Supreme Court pushes aside moral considerations in order to remain neutral on issues of political controversy. As noted earlier, he demonstrates the prominence of the Court's neutrality rationale by analyzing the Court's jurisprudence in the areas of religious liberty, free speech, and privacy (discussing abortion, contraception and homosexuality), and he also addresses development of no-fault divorce. With regard to no-fault divorce, Sandel believes that it penalizes married women who choose to be "homemakers of traditional marriages" 207 and who are, postdivorce, then subject to the morally neutral demand of self-sufficiency. The award of temporary alimony, the result of the no-fault approach, ignores the reality that homemakers have lower earning capacity because they "devoted their lives to child rearing while their husbands pursued careers." ${ }^{208}$ As a result, he asserts, the liberal approach actually reduces women's choices, because it forces them to hedge their bets against divorce and pursue careers even if that pursuit is contrary to their self-identity. ${ }^{209}$ Sandel's legal targets reflect his middle-class bias. Obviously, his discussion of family law has little resonance in communities dominated by single-parent families, where employment for any parent is hard to come by.

Likewise, while the constitutional issues Sandel analyzes are all areas essential to fundamental human rights and personal dignity, they are not hot button issues facing inner-city residents. In inner-city neighborhoods, the greatest risk of government oppression does not come from a lack of respect for religion, speech, or privacy, or from overly-permissive divorce laws. Rather, members of those communities are resisting governmental intrusions in the form of unlawful searches and seizures and racial profiling, loss of procedural protections in the receipt of public benefits, loss of public and subsidized housing, lack of adequate education and health care, and lack of access to legal representation in all of these areas. In other words, the government plays a far more central role in the daily life of the poor, as both a potential oppressor and lifeline, and the most complex legal disputes for the poor center on mediating those tensions. Successful reconciliation of those tensions would likely do more to enhance civic participation than a

207. SANDEL, DemocracY's Discontent, supra note 2, at 113.

208. Id. at 111 .

209. Id. at $114-15$. 
jurisprudential change in speech and privacy cases, as Sandel favors. That is, with less fear of government intrusion and fairer treatment by government bureaucracies, residents of distressed communities might see more hope for positive outcomes through civic involvement.

The moral bracketing that Sandel identifies in his analysis of Supreme Court cases does not happen in cases that affect the poor. That is, when public benefits are at issue, the Court is quite willing to make moral judgments about individuals who fail to live up to the Court's moral vision. Thomas Ross has demonstrated how, in cases involving the poor, the Court regularly states or implies that poor people "are unwilling to work and especially likely to commit fraud or child abuse, or to violate other legal and moral norms. They have bad attitudes and are the cause of their own poverty." ${ }^{210}$ As Ross explains, the Court has bought into the rhetoric of poverty in political discourse and its demarcation between the deserving and the undeserving. During the expansion of the welfare state in the 1960s and 1970s (a development Sandel abhors), the Court actually looked as though it was changing its view of the poor. For instance, in Goldberg v. Kelly, the Court held that welfare benefits were a form of constitutionally protected property that the state could not deny without notice and a hearing. ${ }^{211}$ In so doing, the Court reasoned that "[f]rom its founding the Nation's basic commitment has been to foster the dignity and well-being of all persons within its borders. We have come to recognize that forces not within the control of the poor contribute to their poverty." 212 This vision had communitarian overtones, as Justice Brennan stated that welfare benefits would "help bring within the reach of the poor the same opportunities that are available to others to participate meaningfully in the life of the community."213

However, this holistic and realistic view of poverty was short-lived, and the Court quickly pulled back from indications that it might recognize a constitutional right to welfare. Thus, in Dandridge v. Williams, the Court upheld a Maryland statute that capped AFDC benefits once a family had six persons, despite the state's recognition that those families would receive less than the statutorily determined level of need as well as proportionally less than smaller families. ${ }^{214}$ The Court categorized the statute as mere "social or

210. Ross, supra note 4, at 1499.

211. Goldberg v. Kelly, 397 U.S. 254 (1970).

212. Id. at 264-65.

213. Id. at 265 .

214. Dandridge v. Williams, 397 U.S. 471 (1970). 
economic" legislation subject to minimal scrutiny. ${ }^{215}$ In so doing, it rejected the argument that the Maryland statute violated the Constitution's Equal Protection Clause by discriminating against larger families, and accepted the state's purported legitimate interests in "maintaining an equitable balance in economic status as between welfare families and those supported by a wageearner, [and] in providing incentives for family planning . . .".216 By distinguishing between welfare and working families, the Court reinforced the vision of welfare recipients as purposely dodging employment, and by approving of the state's family planning argument, it played into notions of welfare mothers as sexually irresponsible. ${ }^{217}$ This sort of moral reasoning runs throughout the Court's public benefits cases. ${ }^{218}$ Sandel argues against moral bracketing; but the poor would be better served if the Court made fewer moral judgments of them rather than more.

The Court's most recent welfare case looks quite different, because the welfare claimants were successful. Yet, looks are deceiving; the Supreme Court still very much makes moral judgments about the poor. In a major win for welfare recipients, the Saenz v. Ro $e^{219}$ Court relied on the Privileges and Immunities Clause of the Fourteenth Amendment to strike down a provision of TANF that permitted states to pay TANF benefits to new state residents at the level paid by their prior state of residence. Disparities in benefit levels among states meant that the plaintiffs, new residents to California-a comparatively generous state - received much less than individuals who had lived in California for more than one year. ${ }^{220}$ The Court began by

215. Id. at 485 .

216. Id. at 483-84. "And by keying the maximum family AFDC grants to the minimum wage a steadily employed head of a household receives, the State maintains some semblance of an equitable balance between families on welfare and those supported by an employed breadwinner." Id.

217. Ross, supra note 4, at 1519-20.

To see more clearly how the family planning argument draws on the theme of the moral weakness of the poor, one need simply imagine the popular response to a similar state action directed against wage earner families. If the government chose to put a ceiling on the number of dependents that could be claimed for tax purposes, and the state defended that law's rationality as providing "incentives for family planning," the public outcry would be pervasive and impassioned. We would argue that determining the size of the family is a personal choice, beyond the state's interest. We would be offended by the premises of the state's argument, that the state has any interest in the matter or that we have acted in an irresponsible fashion.

Id. at 1520. Ross' thesis is not only that the Court morally reproves the poor, but also that it views poverty as such a hopelessly complex problem that it throws up its hands in defeat.

218. See id. at 1522-38 (discussing Supreme Court caselaw impacting rights of the poor).

219. Saenz v. Roe, 526 U.S. 489 (1999).

220. Id. at 494. For instance, the plaintiffs, as former residents of Louisiana and Oklahoma, would receive $\$ 190$ and $\$ 341$ respectively for a family of three even though the full California grant was $\$ 641$. 
emphasizing its reasoning in Shapiro v. Thompson, a 1969 case that struck down a similar durational residency provision that denied any benefits to new residents, noting a long-standing recognition by the Court " "that the nature of our Federal Union and our constitutional concepts of personal liberty unite to require that all citizens be free to travel throughout the length and breadth of our land uninhibited by statutes, rules, or regulations which unreasonably burden or restrict this movement."'221 The Court's reasoning thus comports with the liberal premises of autonomy and freedom to choose one's destiny. In this case, however, the Court highlighted the morality of the plaintiffs, noting that they were fleeing domestic violence and had moved to California to live with relatives. ${ }^{222}$ The Court also took pains to discount any ill motives on the part of the plaintiffs, noting that the empirical evidence showed that poor people do not move to new states to collect higher welfare checks. ${ }^{223}$ When it comes to the poor, it appears that moral judgments still play a large role in determining Court outcomes, but they can occasionally accrue to the benefit of the poor. The reach of this latter category seems quite limited, however. Indeed, the Court made clear in Saenz that it was concerned with much more than the plight of the plaintiffs.

[W]e need not rest on the particular facts of these cases. [A contrary ruling] would logically permit the State to bar new residents from schools, parks, and libraries or deprive them of police and fire protection. Indeed it would permit the State to apportion all benefits and services according to the past tax contributions of its citizens. ${ }^{24}$

Thus, not only were these particular poor not blameworthy, ${ }^{225}$ but they also shared the same interest in free travel as that shared by all Americans. Saenz

The third plaintiff, a former resident of Colorado with one child, was limited to $\$ 280$ a month as opposed to the full California grant of $\$ 504$ for a family of two. $I d$.

221. Id. at 499 (quoting Shapiro v. Thompson, 394 U.S. 618, 629 (1969)).

222. Id. at 494.

223. Id. at 506 .

224. Id. at 507 (quoting Shapiro, 394 U.S. at 632-33).

225. Dennis Hirsh has pointed out that plaintiffs do far better before the Supreme Court where they can convince the Court that they are not to blame for their economic circumstances, an argument that first had success during the New Deal era. "Where the Court adopts the New Deal premise that individuals are the victims of impersonal economic forces that severely constrain their options, it grants welfare rights claims. Where the Court returns to the Lochner-era premise that individuals possess economic opportunity and can make free choices about employment, it rejects these claims." Dennis D. Hirsch, The Right to Economic Opportunity: Making Sense of the Supreme Court's Welfare Rights Decisions, 58 U. PITT. L. REV. 109, 124 (1996). 
suggests that the morality of the poor is still a factor in Supreme Court decision-making. ${ }^{226}$

While Sandel assumes that taking moral considerations into account would improve the Court's jurisprudence and create better citizens, he provides no answer to the dangers of majoritarianism. The welfare benefits cases highlight this danger. Not only do they impose the will of the majority on a disempowered minority, but they also leave that minority with no buffer against state power. As Carlos Ball has explained in the context of gay rights, "Sandel does not appear to fully appreciate the role that constitutional adjudication plays in protecting the interests and rights of minorities from the will and biases of majorities." 227 For instance, Sandel believes that in free speech cases courts can, and should, distinguish between the Nazis who marched in Skokie and the marchers led by Martin Luther King, Jr. based on "the content of the speech, the nature of the cause." 22 He notes that United States District Court Judge Frank Johnson permitted the 1965 voting rights march from Selma to Montgomery by "passing judgment on the morality of the cause they would advance." ${ }^{229}$ Ball points out that Sandel's approach turns courts into "super-legislatures" free to substitute their opinions for those of lawmakers and just as susceptible to prejudice and bias. ${ }^{230}$ Given the limited gains of the individual rights approach in obtaining constitutional protections for the poor, Sandel may be right that morality should play a greater role in constitutional interpretation. ${ }^{231}$ Yet, the focus should not be on the morality

226. The time-honored approach of condemning the poor for the dire circumstances in which they find themselves was alive and well recently in Department of Housing and Urban Development v. Rucker, 535 U.S. 125 (2002). There, the Court upheld a federal statute that permitted no-fault evictions of tenants whose co-tenants, household members, or guests engaged in drug activity on or off the property - regardless of whether or not the plaintiff was aware of the conduct. $I d$. After highlighting the allegedly illegal conduct at issue (grandsons were smoking marijuana in a parking lot, a daughter was found with crack cocaine three blocks away, and a caregiver was found with cocaine inside a resident's apartment), the Court determined that lack of knowledge was no excuse - tenants who cannot control the behavior of others are a threat to other tenants. $I d$. at 130 .

227. Carlos A. Ball, Communitarianism and Gay Rights, 85 Cornell L. Rev. 443, 480 (2000).

228. Sandel, Democracy's Discontent, supra note 2, at 90. The courts upheld both marches, even though, as Sandel states, "the Nazis promote genocide and hate." Id. According to Sandel, protecting the Nazis "in the name of neutrality may fail to respect persons as members of the particular communities to which they belong, ... [and] fails to acknowledge the injuries that speech can inflict independent of the physical harm it may cause." Id. at 89.

229. Id. at 90 . By contrast, "the Nazis promote genocide and hate." Id.

230. Ball, supra note 227, at 481.

231. Since Sandel wrote Democracy's Discontent, the Court has become more willing to make moral judgments that arguably promote civic society values. For instance, the Court has approved of public financing of religious primary education through school vouchers, holding that neutrality requires that the government treat secular and sectarian alike; not that it remain neutral on sectarian matters. Zelman v. 
of the poor, but on the morality of a nation that permits ever-increasing levels of income inequality.

\section{B. Michael Walzer}

Michael Walzer advances a communitarian, egalitarian vision he calls "complex equality" in his book, Spheres of Justice. ${ }^{232}$ Whereas Sandel prescribes republicanism as his vision of the "good," Walzer defers to particular political communities to define their own vision of the "good." Under complex equality, social goods are distributed according to shared understandings within political communities, and possession of one social good cannot lead to domination over other social goods. Walzer is considered communitarian because he rejects universal principles of justice in favor of principles that arise out of particular communities and that are shared within them. His idea of complex equality provides a powerful rejoinder to inequality. It also forces us to engage in serious contemplation and debate about what constitute needs in our society and how those needs should be satisfied. Nevertheless, complex equality undercuts its own promise because it never solves the problem of how to give voice to the voiceless. As a result, it is a powerful tool for reflection, but a weak one for action.

\section{Complex Equality}

To get to complex equality, Walzer rejects the Rawlsian construct of defining principles of justice through hypothetical and unknowing persons. Walzer asserts that real people, situated within actual communities, would not make the same choices as Rawls's seemingly indistinguishable persons. ${ }^{233}$ Accordingly, he aims to root his philosophy squarely within our own current and concrete society. ${ }^{234}$ Walzer's political actors make choices based on their own characteristics and their own situations. He repudiates attempts, like those of Rawls, to discern universal principles of justice, contending that such overarching principles are divorced from history and context. ${ }^{235}$ Rather than

Simmons-Harris, 536 U.S. 639, 655-57 (2002). The rationale of that case probably extends to charitable choice provisions in TANF that permit government funding of religious groups that deliver social services. Clearly, the Court is now taking "religion seriously," in a way that Sandel found lacking in 1996-although they still do so under a guise of "neutrality."

232. WALZER, supra note 12.

233. Id. at 5 .

234. $I d$.

235. Id. at xiv. 
"climb the mountain" to fashion a "universal standpoint," he "mean[s] to stand in the cave, in the city, on the ground."236

Given his committed orientation to the here and now, Walzer's project is to advocate for a society in which no single social good serves as a vehicle for domination. ${ }^{237}$ In such a society, possession of one social good, such as money, should not lead to dominance in another unrelated sphere, such as political power or ecclesiastical office or education. ${ }^{238}$ Thus, instead of "simple equality," in which everyone has the same amount of goods, Walzer advocates "complex equality," in which people have differing amounts of social goods, but possession of one social good does not translate into domination in other spheres. As he puts it, "[n]o social good $x$ should be distributed to men and women who possess some other good y merely because they possess $y$ and without regard to the meaning of $x$. "239 According to Walzer, each social good has its own meaning derived from society's shared understandings. From these shared meanings, we can derive the proper criteria for distributing social goods. ${ }^{240}$ The social goods Walzer is concerned with include membership, security and welfare, money and commodities, office, hard work, free time, education, kinship and love, divine grace, recognition, and political power, and he focuses at length on each of these in his book, describing the shared understandings within each sphere. ${ }^{241}$

According to Walzer, "a given society is just if its substantive life is lived a certain way - that is, in a way faithful to the shared understandings of the members." ${ }^{242}$ This leads to a certain amount of moral relativism. In a muchcriticized argument, Walzer contends that inequality may be just in certain societies, such as the caste system in India. ${ }^{243}$ In the caste system, inequalities are "justified by customary rules and an overarching religious doctrine." 244 Equalizing distribution among castes would "require a radical redesign of the village against the shared understandings of the members." ${ }^{245}$ For Walzer,

241. By comparison, Rawls lists his primary goods in broader terms because his hypothetical people do not know in particular what they want. RAwLS, supra note 7, at 92 .

242. WALZER, supra note 12, at 313.

243. Id. at 84 .

244. Id. at 313 .

245. Id. 
justice is achieved when distributions are made in accordance with shared understandings.

\section{A Critical Assessment of Complex Equality}

Walzer's particularistic approach holds some promise for distressed communities. Although he seems to read "community" at the level of nation states, his analysis could apply equally to smaller levels of community, such as neighborhoods. At this more localized level, a Walzer analysis could find value in the norms and history shared within distressed communities, while avoiding judging those communities against middle-class values. A nonjudgmental and particularistic examination of distressed communities can also reveal hidden assets that policymakers could build upon in designing welfare systems. Walzer's theory also provides a strong (albeit obvious) critique of the link between money and access to other social goods. He forces us to question how we distribute social goods and which ones are truly needed to create an egalitarian society.

However, although Walzer is clearly sympathetic to the plight of the poor and other disadvantaged members of society, ${ }^{246}$ his approach does not ultimately help them. Walzer contends that the first thing that members of a political community owe to one another is communal provision of security and welfare, and that these goods should be distributed by need. ${ }^{247}$ However, recognizing that needs come in varying degrees and priorities, Walzer proposes that needs should be satisfied according to political solutions. For example, he notes that the ancient Athenians provided for public baths and public theater, but not public education. Their distributions were based on their own conception of what was necessary for membership in their specific political community. By contrast, medieval Jewish communities provided for public education and material assistance for the poor based on their religious beliefs - again, according to the shared understandings of what was needed in their society. ${ }^{248}$ Walzer maintains that we cannot pass judgment on these communities' choices.

To demonstrate the sort of communal provision that is appropriate in our American society, Walzer focuses on the provision of health care. He claims

246. Id. at 84 ("I think, that the citizens of a modern industrial democracy owe a great deal to one another . . the United States currently maintains one of the shabbier systems of communal provision in the Western world.").

247. Id. at 64 .

248. Id. at 71-74. 
that longevity is a "socially recognized need," and that Americans believe that all citizens deserve equal chances at long and healthy lives. ${ }^{249}$ From this nonempirical assessment of perceived need, he concludes that the private market for medical care should be abolished and that doctors should be public employees. He notes that the government plays a strong role in supplying health care by subsidizing medical research, training doctors, and providing public medical assistance for the very old and very poor. ${ }^{250}$ Government is engaged in these activities because its citizens want them. Thus, once the citizenry identifies such a need, Walzer states that the need must be provided for equally to all members of the community. ${ }^{251}$ America violates this principle: the rich are able to purchase better care than the poor because our society relies on the market - instead of need - as our distributional criteria. So, the government subsidizes a market that, in turn, unfairly distributes its commodity of health care. In sum, Walzer advocates for a public health care system because Americans want one. Regardless of the merits of a public health system, we can decisively say - twenty years after Walzer wrote Spheres of Justice - Americans do not, at this time, want it. Or, perhaps more accurately, the elected representatives of Americans who are engaged in the political process have rejected it.

Obviously, Walzer is making a circular argument. He endorses the political process when its definition of need conforms to his, and he rejects it when his own view diverges from political realities. This is the downfall of relying on shared understandings; its ultimate implications are majoritarian, and this has never been good for marginalized groups. Walzer's focus on shared understandings as the definitive criteria for distributing social goods bodes ill for Americans living in poverty. Simply put, Americans have been stingy in how they define need. Americans do not want people starving in the streets, but, at the same time, we are reluctant to subsidize individuals who do not work for their income. Our current welfare system is the result of a political process, and it pointedly does not attempt to meet basic needs. The very premises of TANF - the focus on assistance as temporary and the law's emphasis on personal responsibility - reveal the law's rejection of need as the standard for delivering aid. Significantly, TANF does not require that states pay any particular level of benefits to eligible recipients. To the contrary, states do not have to provide cash assistance at all. TANF's focus is on 
reforming and punishing deviant behavior, not providing a social safety net. ${ }^{252}$ TANF does not acknowledge that structural conditions create poverty; instead, it presumes that individual failures create poverty. So, instead of economic reforms, it aims to reform individuals.

Walzer convincingly points out the corrupting influence of money on the political process. Indeed, complex equality is focused on de-linking money from other spheres of social goods. Yet, Walzer naively relies on the political process as the best embodiment of our shared understandings. In reality, the political process represents the shared understandings of only a portion of society. Poor people have little impact on politics, and thus, it is hard to call any political outcome as the result of a truly shared perspective across economic classes. ${ }^{253}$ Money is a controlling force in dictating political outcomes. The dominance of money is rooted in the financial structure of our electoral system, in which "monied interests organized around their relationship to wealth dominate the fundraising process that, to a large extent, determines which candidates for public office will win and what they will do once elected." ${ }^{254}$ In addition, due to a lack of meaningful educational opportunities, the poor vote in exceedingly low numbers, further lessening the impact of their voice on politics. ${ }^{255}$ The poor also lack a unified political

252. Under AFDC, states were required to establish a statewide standard of need, based on the state's evaluation of what was essential to meet basic living standards, although they did not have to pay the difference between a family's countable income and the statewide standard of need and could pay only a portion or percentage of that amount. See Burns, supra note 30, at 226. Nevertheless, there was some conception that AFDC was designed to meet some level of need, variously defined by the states. Id. By contrast, TANF does not refer to need as a payment standard at all, leaving states with full discretion to set payment levels at any level they choose, for any reason.

253. Walzer responds to inequitable implications of his work by focusing on the potential of dissent to foment social change. WALzer, supra note 12, at 12. But, as Susan Moller Okin has pointed out in her feminist critique of Walzer, "[t]he more thoroughgoing the dominance, and the more pervasive its ideology across the various spheres, the less chance there is that the whole prevailing system will be questioned or resisted." Susan Moller Okin, Justice, Gender, and the Family 64 (1989). Moreover, "those to whom caste, class, race, or gender structures deny education are far less likely to acquire the tools needed to express themselves in ways that would be publicly recognized were they to interpret shared meanings literally and turn them into social criticism." Id. at 66-67. The feminist critique of communitarianism is highly relevant to any discussions of poverty, given the feminization of poverty - the poverty rate of women is twenty-six percent higher than the male poverty rate, fifty-seven percent of the poverty population consists of women, and 17.6 percent of families are headed by women. See ICELAND, supra note 108, at 87-94.

254. Jamin Raskin \& John Bonifaz, Equal Protection and the Wealth Primary, 11 YALE L. \& PoL'Y REV. 273, 274, 274-75 nn.10-11 (1993).

255. "The lower the income, the lower the rate of voter turnout." DAvid K. SHIPLER, The Working POOR 287 (2004). In the presidential election of 2000, "[t] $\mathrm{hree-quarters} \mathrm{of} \mathrm{those} \mathrm{with} \mathrm{family} \mathrm{incomes} \mathrm{over}$ $\$ 75,000$ voted, 69 percent of those earning $\$ 50,000$ to $\$ 75,000$, and so on down to a mere 38 percent of 
movement that advocates for their interests. ${ }^{256}$ Moreover, TANF's devolution of authority to the states ensures that the poor will remain estranged from policy debates, because state level politics are more hostile to claims of redistribution than federal decision-making. ${ }^{257}$ For all these reasons, the poor have little say in how the welfare policies that affect them are shaped.

Walzer is sympathetic to the plight of the poor, and accordingly unhappy with many of our political outcomes. Walzer recognizes that wealthy members of society can, and historically often have, dominated patterns of distribution to the detriment of the poor. Yet, he fails to identify an alternative way to move towards a more generous interpretation of our shared understandings that is consistent with his emphasis on particularism. Walzer hints at one option when he notes that historic patterns of domination by the wealthy over the poor are the result of a "fraud of the social contract." ${ }^{258}$ This suggests that removing the barriers that limit the access of the poor to the political process would result in fairer, more inclusive shared understandings. Removal of these barriers, however, would require the poor, or institutions that serve the poor, to have more money - and redistribution of capital is not where Walzer is willing to go.

Another option is to reject the notion of shared understandings altogether, and to identify need based on more universal principles of justice. Such a liberal approach, however, is the exact opposite of where Walzer is trying to move us. ${ }^{259}$ Yet a third approach would hypothesize what our politics would look like without the corrupting influence of money. Walzer believes that

those whose households took in less than $\$ 10,000$ a year." Id. In addition, Shipler notes that over two million prisoners and ex-convicts are ineligible to vote. $I d$.

256. Although there was a significant welfare rights movement in the 1970 s that led to the enhancement of individual procedural rights in the welfare arena, there is no such national movement today for a variety of reasons, including the increasing concentration of poverty, institutionalized racism, limited access to lawyers and limitations on poverty lawyers, and a concerted strategy on the part of anti-poverty activists to move towards locally-based renewal efforts. Scott L. Cummings, Community Economic Development as Progressive Politics: Toward a Grassroots Movement for Economic Justice, 54 STAN. L. Rev. 399, 405-07, 421-29 (2001) [hereinafter Cummings, Progressive Politics]. But see Frances Fox Piven, Welfare Movement Rises, NATION, May 8, 2000, at 4, 5 ("Below the radar screen of press and politicians, scores of grassroots groups are waging fights at the local and state level to expose the realities of welfare reform and the low-wage labor market. ... There are signs that these local efforts are coalescing into a national movement ....").

257. See Sheryll D. Cashin, Federalism, Welfare Reform, and the Minority Poor: Accounting for the Tyranny of State Majorities, 99 Colum. L. Rev. 552, 582-83 (1999), discussed infra at notes 393-95 and accompanying text.

258. WALZER, supra note 12 , at 83 .

259. Id. at 79 . 
politicians should persuade with their words, reasoning, and argument. ${ }^{260}$ This "pure" political process would presumably yield a more accurate conception of need. Imagining such a process is difficult. Moreover, the policies that would emerge from such an untainted process would not reflect our current shared understandings, but rather the shared understandings of a radically different society. Thus, Walzer ends up promoting the sort of hypothetical construct that he is at pains to distinguish himself from. Furthermore, by endorsing a pure democracy, Walzer arrives at just the sort of universal, human right that he contends is inappropriate in conceptualizing justice. $\mathrm{He}$ arrives back at liberalism. ${ }^{261}$ This certainly suggests that it may be impossible to improve the plight of the poor without relying on underlying values of liberalism: equality, dignity, and basic rights.

Unable to escape this conundrum, Walzer takes a fourth approach in his example of health care. He defines need himself, based on an impressionistic and overly generous assessment of his sense of the American public. This is not a shared understanding; this is Walzer's understanding. While it is a compassionate understanding, it is not one based on any principles that could be extended in a principled way to aid the poor. He claims that our shared understanding is based on a "want' so widely and deeply felt that it can plausibly be said that it is . . of the community generally." ${ }^{262}$ He concludes that if society marks something as a want, it must be provided to the entire community equally. This suggests that identifying shared understandings requires us to look at what basic goods wealthy Americans possess and how much they possess, and then distributing that commodity equally across the income spectrum. In general, people want what richer people have. This approach, however, conflates wants with needs, and does not provide a helpful demarcation between the two.

Our shared understandings are much more complicated-and far less unified - than Walzer suggests. Indeed, when it comes to the poor, Americans do not share in any collective conception of need. In polls, only one in ten Americans say that poverty is among the most important issues government should address, although a majority of Americans consider poverty to be a

260. Id. at 304.

261. See Robert B. Thigpen \& Lyle A. Downing, Liberalism and the Communitarian Critique, 31 AM. J. PoL. SCI. 637, 649 (1987) ("Liberals insist that persons have a human right to be persuaded in political matters because of their capacity for rationality and moral choice. By arguing that political participants should exclude considerations irrelevant to rational argument, Walzer in effect insists that citizens should assume the constraints of abstract deliberators who ignore their own particular characteristics.").

262. WALZER, supra note 12, at 88. 
"big" problem. Half of all Americans say that the poor are not doing enough to lift themselves out of poverty, while half say that poverty is caused by circumstances outside their control. Of Americans who earn twice the poverty level, half say the poor could survive without welfare if they tried, and half say they could not. Half say that poor people lead easy lives because they live off of the government dole; half disagree. ${ }^{263}$ One thing that does unite Americans is the value of work. "Americans appear to value work so strongly that they support welfare reform even if it leads to jobs that keep people in poverty." 264 At the same time, fifty-six percent of Americans would accept a tax increase to support government programs that are designed to help people help themselves, such as job training programs, an expansion of day care, and increased tax credits. ${ }^{265}$

Americans obviously have conflicting understandings with regard to the poor. In circumstances of conflict, Walzer states that "society [should] be faithful to the disagreements, providing institutional channels for their expression, adjudicative mechanisms, and alternative distributions. ${ }^{266}$ Our institutional channels and adjudicative mechanisms lie in our court system. On that front, the poor have not fared particularly well. ${ }^{267}$ The Supreme Court has rejected a constitutional right to welfare, instead subjecting legislation related to social and economic programs to a deferential rational basis review. Moreover, as Part II.A. explains, the liberal conception of personhood employed by the Court often means that the poor are denied relief when the Court deems them undeserving or blameworthy. The Court's decision to provide the poor with procedural, rather than substantive, rights means that legislatures have the power to decide whether welfare is a constitutionally protected entitlement or not. In TANF, Congress chose the latter. Thus, Court doctrine generally reinforces and supports the majoritarian impulse in poverty policies. Walzer's reliance on adjudicative mechanisms again undermines attempts to secure equality for the poor.

263. NPR/Kaiser/Harvard University's Kennedy School of Government, Poverty in America (results of polling conducted in Jan. and Feb. 2001), available at http://www.npr.org/programs/specials/poll/ poverty/ (last visited Mar. 4, 2005). Only one-third of low-income Americans agree that poor people lead easy lives because they live off the government. $I d$.

264. $I d$.

265. $I d$.

266. WALZER, supra note 12, at 313.

267. See Robert Rubinson, A Theory of Access to Justice, 29 J. Legal Prof. 89 (2005) (arguing that a disproportionate share of the judicial and legal system's resources are directed at economically powerful claimants). 


\section{Amitai Etzioni and Communitarian Politics}

Amitai Etzioni is the political voice of communitarianism. He is a sociologist and founder of the communitarian movement, which was established to disseminate communitarian policy prescriptions to the public and policymakers and to make the case for a centrist way between radical individualism and authoritarian moralism. ${ }^{268} \mathrm{He}$ has been credited with influencing the politics of President Clinton, English Prime Minister Tony Blair, and other politicians, such as Senator Bill Bradley, who are interested in staking out a centrist, middle ground. ${ }^{269}$ Political communitarians want to slow the minting of new rights and the resultant notion of self-entitlement without reciprocal commitments. ${ }^{270}$ While these communitarians tend to promote a "grab bag" of somewhat moralistic policies, they also are forthright about acknowledging the importance of rights in a regime of collective responsibility. They do not seek to eliminate individual rights, but to balance them with communal values. This idea of balance is particularly helpful in conceptualizing rights within poor communities.

\section{Etzioni and a Return to Values}

Etzioni is responding to the modern state of "moral confusion and social anarchy," 271 that he believes arose when the strong moral code of the 1950s dissolved in the $1960 \mathrm{~s}$, only to be replaced by a moral vacuum taken over by right-wing extremists. ${ }^{272}$ Etzioni is sensitive to the fact that many values of the 1950s were authoritarian, patriarchal, and discriminatory to women and minorities, ${ }^{273}$ but he believes that the breakdown of the strong moral order of the 1950s has lead to "unbounded relativism, situational ethics, and excessive individualism." ${ }^{274}$ For Etzioni, the answer lies in finding a balance between rights and responsibilities, with neither dominating. ${ }^{275}$ Etzioni asserts that this balance is best struck by and within communities.

According to Etzioni, communities - not the market or the governmentshould be the source of moral values and serve as a source of moral suasion

268. Etzioni, New Golden Rule, supra note 14, at 9.

269. Robert S. Boynton, The Everything Expert, NATion, July 14, 2003, at 25.

270. Etzioni, Spirit of Community, supra note 1, at 5-10.

271. Id. at 12 .

272. Etzioni, New Golden Rule, supra note 14, at 61-64.

273. EtZioni, SPIRIT Of Community, supra note 1, at 22-26.

274. EtZIOni, NeXt, supra note 14, at 21.

275. Etzioni, SPIRIT of Community, supra note 1, at 4. 
for their members. ${ }^{276}$ Communities can use "subtle and informal social regulating processes, such as approbation and censure,"277 and serve as a buffer against the state. ${ }^{278} \mathrm{He}$ defines communities as groups that "transmit a shared moral culture from generation to generation, as well as constantly reformulating this moral framework over time," ${ }^{279}$ and he conceives of them as geographically based. ${ }^{280}$ Thus, for Etzioni, the key to solving our social problems is to cultivate existing communities and to formnew ones. ${ }^{281}$ Unlike Sandel and Walzer, Etzioni believes that the majoritarian dangers of communities can and should be counter-balanced by enforcement of the Bill of Rights and the "overarching values" we all share. ${ }^{282} \mathrm{He}$ also asserts that these dangers are minimized because people today belong to many communities and have multiple sources of attachments, thus insulating them from dominance by any one particular group. ${ }^{283}$

Etzioni's policy proposals "run the gamut-depending on your perspective - from innocuous do-gooderism to authoritarian intrusiveness." 284 For instance, major tenets of the communitarian platform and Etzioni's own writings include the propositions that parents should spend more time with their children rather than focusing on personal advancement; ${ }^{285}$ families should have two parents; divorce should be avoided through marriage counseling programs and waiting periods should be required before divorce is granted; schools should provide moral education; and people with AIDS should inform their partners and health care workers. ${ }^{286}$ The platform also calls for a national service program, campaign finance reform, sobriety checkpoints, and drug and alcohol testing for people who affect public safety. Issues of poverty and welfare receive scant attention from the communitarian

276. Etzioni, NeXt, supra note 14, at 2, 5, 11; EtZioni, Spirit of Community, supra note 1, at 31, 37, 39; EtZioni, New Golden Rule, supra note 14, at 16, 27.

277. Etzioni, NeXt, supra note 14, at 23.

278. Etzioni, Spirit of Community, supra note 1, at 15; Etzioni, New Golden Rule, supra note 14 , at 23 .

279. ETZIONI, NEXT, supra note 14, at 6.

280. Id. at 14 .

281. Id. at 7-8.

282. EtZioni, Spirit of Community, supra note 1, at 37, 39, 53.

283. Id. at 347-48; Etzioni, New Golden Rule, supra note 14, at 127-30.

284. Boynton, supra note 269 , at 25.

285. Etzioni acknowledges that low-income families have no choice but to work, but suggests that their materialistic aspirations are too high and that they could make do on less. Etzioni, SpiRit of Community, supra note 1 , at 65-66.

286. Id. at $247-51,256-58$ 
platform or in Etzioni's other writings, ${ }^{287}$ although more recently Etzioni seems concerned about the harshness of the 1996 welfare reform statute and more ready to call for a government safety net of last resort.

With regard to poverty, the communitarian platform states that community members should provide for themselves and their families through "honorable work," and bear responsibility for the material well-being of others. ${ }^{288}$ If those mechanisms fail, "vulnerable communities" should obtain assistance from more endowed communities as well as public-private partnerships. ${ }^{289}$ Under the platform, the brunt of providing for the needy falls on communities; government should step in only when "other social subsystems fail. ${ }^{290}$

Etzioni's other writings also echo this emphasis on a localized response to poverty. He claims that human dignity is fostered when people exercise their "moral responsibility to help themselves as best as they can" because dependency is degrading and lessens the likelihood of community assistance. ${ }^{291}$ Communities are a better source for poor support than the government, because they better know what their members need. ${ }^{292}$ Etzioni urges wealthier communities to help out the less affluent with food, blankets, and volunteers. ${ }^{293}$ He thinks welfare reform went too far in punishing the poor, and he sees some role for government to ensure that people, including non-workers, have the basic necessities of life as a way to affirm their basic humanity, but urges further dialogue on how much and what types of relief should be available. ${ }^{294}$ Etzioni also makes some policy proposals designed to ease the growing gap between the rich and poor, including expanded Head Start and job training programs, a raise in the EITC and minimum wage, emphasis on homeownership programs for the poor, better transportation options to link the poor with available work, and an elimination of tax breaks for the rich. ${ }^{295}$ His recommendations are sound ones, but essentially the same as those of liberal egalitarians, and, surprisingly, many of them value autonomy over community. Most liberals would advocate for improving the

287. The topic takes up four pages in the 267 pages of Spirit of Community. Id. at 260-64.

288. Id. at 264 .

289. Id. at 260

290. Id. at 260-61.

291. Id. at 144 (emphasis omitted).

292. Id. at 146

293. Id.; EtZIOni, NeXt, supra note 14, at 12.

294. Etzioni, Next, supra note 14, at 29, 53; Etzioni, New Golden Rule, supra note 14, at 54, 83 (stating that people need the psychological security that they will not be destitute).

295. Etzioni, NeXt, supra note 14, at 101-06. 
financial situation of individuals, which would be a welcome improvement, but would not necessarily strengthen communities. These policies would signal a national commitment to alleviating the conditions of poverty, but Etzioni and other communitarians make clear that affluence alone does not lead to the sense of community they seek to foster. Etzioni surprisingly rejects many community-building alternatives, such as job training programs for the unskilled and economic development programs, because they are too slow and "frequently unsuccessful." 296 While he is correct that these programs are not quick solutions, he is far too pessimistic about their results or potential; these types of programs have made tangible improvements in many poor neighborhoods. ${ }^{297}$

\section{A Critical Assessment of Etzioni}

Several of Etzioni's ideas are helpful in thinking about community responses to poverty, such as the idea of collective responsibility for ensuring a basic minimum for all Americans. Other ideas - such as the notion that wealthy communities send blankets and food to the less affluent — are almost hokey in their naiveté about the severity and complexity of problems associated with poverty. In addition, Etzioni and his fellow communitarians place too much responsibility for alleviating poverty on the very communities suffering its scourge. It is too much and too unfair to ask these hard-pressed and resource-starved neighborhoods to solve problems they did not create, although they surely need to be an integral part of the solution. "The idea that poor neighborhoods contain the resources and capacities for their own regeneration can be, and often has been, used to promote self-help without the requisite external support and linkages." ${ }^{298}$ The self-help approach also ignores the governmental role in perpetuating segregation. ${ }^{299}$

Etzioni is far more helpful in confronting the risks of majoritarianism posed by communitarianism. He attempts to resolve that problem by maintaining equilibrium between a voluntary moral order and autonomy. Whereas Sandel puts the good before the right; Etzioni attempts to balance the

296. Id. at 103 .

297. See generally William H. Simon, The Community Economic Development Movement: Law, Business, and the New Social Policy (2001) (describing the many successes of the CED movement and its potential to relieve conditions of poverty). See also discussion of the Dudley Street Neighborhood Initiative at notes 363-85 and accompanying text.

298. Robert Halpern, Rebuilding the Inner City: A History of Neighborhood Initiatives to AdDress Poverty in the United States 222 (1995).

299. See supra Part I.E. 
good and the right. He thus articulates a significant role for individual rights within a communitarian vision. For Etzioni, the Bill of Rights is a "depository of societal values" that serves as a check against majoritarian values. ${ }^{300}$ Thus, he would not endorse a welfare system that violated constitutional protections, even if it was the result of democratic deliberation. Yet, the Constitution alone does not provide a complete check upon majoritarianism, because the boundaries of the rights articulated in the Constitution are ambiguous and open to interpretation. For instance, although the Supreme Court has not interpreted a right to welfare from the Constitution, others have articulated convincing arguments to the contrary from the same text. ${ }^{301}$ Thus, even constitutional interpretation is subject to the pull between individual rights and social order, and must be compared against some external norm. Etzioni's external norm consists of morally self-evident values, such as globally-shared prescriptions against lying and the idea that one owes a higher obligation to one's own children than to others. ${ }^{302}$ The values he ultimately settles upon as the outer limit on community voices are moral order and autonomy. Thus, although he de-emphasizes the role of the courts in shaping our moral voices ${ }^{303}$ it seems that he would evaluate constitutional interpretation by how well it balances these competing tensions.

As a practical matter, he states that society can usually achieve this balance by following four guidelines: (1) autonomy should not be limited unless there is a "clear and present danger"; (2) any danger should be responded to "without resorting to autonomy-restricting measures"; (3) any autonomy-restricting measures should be "minimally intrusive"; and (4) any side effects should be minimized. ${ }^{304}$ TANF permits states to adopt policies that limit individual rights and autonomy, such as drug testing for welfare recipients and a denial of benefits to children born to families receiving welfare. ${ }^{305}$ Etzioni provides a helpful way to assess these provisions. These

300. Etzioni, New Golden Rule, supra note 14, at 224.

301. See, e.g., Forbath, supra note 32, at 1821.

302. Etzioni, New Golden Rule, supra note 14, at 241-52.

303. Id. at 138-40. His de-emphasis on the courts as a potential for moral order is critiqued in Linda E. Fisher, Alcohol, Tobacco, and Firearms: Autonomy, the Common Good, and the Courts, 18 YALE L. \& PoL'y ReV. 351, 353 (2000) (book review).

304. Etzioni, New Golden Rule, supra note 14, at 51-53.

305. There are other individual rights potentially imperiled by TANF. For instance, TANF's disclaimer of benefits as an entitlement may eliminate Fourteenth Amendment rights to procedural due process before benefits are reduced or denied. See Gilman, Accountability, supra note 79, at 569. Likewise, TANF's charitable choice provisions may violate First Amendment protections against government establishment of religion. See Gilman, Charitable Choice, supra note 78, at 862-71. Certain TANF provisions regulating marriage and child support enforcement may violate constitutional rights to 
behavior-modification policies generally fail under step one of Etzioni's framework. That is, they respond to stereotypes where empirically, there is no danger. For instance, family cap provisions deny benefits to children born while their mother is on welfare as an incentive to reduce family size among the poor. This obviously reduces the autonomy of mothers on welfare to plan their families as they see fit without moral condemnation or financial penalties, just as middle-class Americans do. ${ }^{306}$ Yet, while the family cap may reflect the moral voice of mainstream Americans, it does not respond to a clear and present danger. The average welfare family is the same size as a middle-class family. ${ }^{307}$ Moreover, there has never been a proven link between receipt of public benefits and family size. ${ }^{308}$ The Supreme Court reviews conditions attached to public benefits under a rational basis test, reasoning that the government can discourage behaviors it disproves. Yet, Etzioni's clear and present danger test suggests such restrictions on autonomy should be subject to a compelling state interest test-a test they would likely fail. Moreover, as Etzioni points out, there are often less-intrusive means for achieving desired social order. Thus, for instance, concerns about large families in poverty could be addressed through educational or hortatory means. Limiting autonomy is not a necessary route. Thus, unlike other communitarians, Etzioni takes pains to demonstrate how the social good can be pursued without a sacrifice in individual rights. This balance is essential in any welfare scheme, given the expansive role the government plays in the lives of the poor.

\section{Poor Communities and Social Capital}

Although communitarian thinkers have largely neglected, or grossly simplified, the causes and symptoms of poverty, their theoretical emphasis on shared values and their desire to strengthen communities provide an alternative foundation for thinking about welfare. Currently, welfare is directed at improving individuals through work and behavioral modifications.

family privacy and free association. See Susan L. Thomas, "Ending Welfare As We Know It," Or Farewell to the Rights of Women on Welfare? A Constitutional and Human Rights Analysis of the Personal Responsibility Act, 78 U. Det. Mercy L. Rev. 179, 190-98 (2001).

306. In fact, middle-class Americans are awarded benefits for having children through tax deductions. See Internal Revenue Service, Publication 501, Exemptions, Standard Deduction, and Filing INFORMATION (2003).

307. Anna Marie Smith, The Sexual Regulation Dimension of Contemporary Welfare Law: A Fifty State Overview, 8 Mich. J. GeNDER \& L. 121, 170-72 (2002).

308. $I d$. 
Not surprisingly, this approach has been a failure, given that poverty rarely results from individual failings and that poor people are encumbered by numerous relationships and dependencies that make achieving the goals of welfare reform difficult. The failure of financial incentives and work requirements to coerce desired behavior is not the result of inadequate incentives or improper implementation as policymakers tend to assume, ${ }^{309}$ but rather from an inadequate understanding of how those incentives play out in the lives of the poor. The reality is that poor people deal with so many competing pressures that "inducements that seem powerful in isolation can become peripheral in context" or can diverge so sharply from the realities of daily life that they become meaningless. ${ }^{310}$ Communitarian theory could (but currently does not) support a community-based approach to welfare that would build upon and create assets within distressed neighborhoods. Rather than assuming the worst of the poor, it would build upon the best these communities have to offer. Rather than blaming the poor for their status, it would seek to involve them in bettering their environments.

Inner-cities, whose residents were the targets of welfare reform, have suffered from a widespread perception that they lack any attributes whatsoever of meaningful community. Indeed, they have been portrayed as teeming with social disorganization, ${ }^{311}$ and, regrettably, communitarian theorists appear to accept this portrayal. To the degree that any "shared values" exist at all in inner-cities, they are presumed to be degenerate- the approval of sexual permissiveness, single motherhood, gang violence, drug trafficking, truancy, and the like. ${ }^{312}$ To be sure, there are inner-city residents who suffer from "culturally destructive behavior and attitudes," as well as increasing isolation from mainstream society. ${ }^{313}$ This focus on isolation, although "striking and

309. See Ann Chih Lin, Social Contexts in the Making of Public Policy, in Coping with Poverty: The Social Contexts of Neighborhood, Work, and Family in the African-Americ an Community 262, 262 (Sheldon Danziger \& Ann Chih Lin eds., 2000) [hereinafter Coping With PoverTy].

310. Id. at 263 .

311. See Elise M. Bright, Reviving America's Forgotten Neighborhoods 1 (2000) (summarizing the popular perception that inner-city problems are "the fault of the people who live there"). "[P]ublic housing tenants have been systematically represented in the media and in more scholarly publications as humanly as well as financially destitute, destined for lives of unemployment, dysfunction, and crime." Mark R. Warren et al., The Role of Social Capital in Combating Poverty, in Social CAPITAL AND Poor Communities 1, 22 (Susan Saegert et al. eds., 2001).

312. See Susan Bennett, "The Possibilityof a Beloved Place": Residents and Placemaking in Public Housing Communities, 19 St. Lous U. PuB. L. Rev. 259, 270 (2000) (discussing the "popular conception that community cannot grow in public housing").

313. See Wilson, When Work Disappears, supra note 121, at xviii; Gina Barclay McLaughlin, Communal Isolation: Narrowing the Pathways to Goal Attainment and Work, in COPING WITH PoverTy, 
well-founded . . . can encourage policymakers to believe that poor communities have no structure left to build on, no interactions to be preserved, and no points of contact between their neighborhoods and the wider world." ${ }^{14}$

Yet, despite formidable odds, most poor neighborhoods exhibit elements of meaningful social organization. ${ }^{315}$ That is, their residents have extensive kinship and social networks that provide emotional support, material resources, and mutual aid. ${ }^{316}$ In recent years, sociologists have studied these networks and found "intricate social structures and networks within the poorest communities," as well as a "distinctive politics among the poor." 317 These studies focus less on perceived pathologies in poor communities and more on assessing their "social capital." Social capital consists of the "resources that inhere in social relationships," such as "mutual trust, a sense of reciprocal obligation, and civil participation aimed at benefiting [sic] the group or community as a whole." ${ }^{318}$ Likewise, communitarians are concerned with "develop[ing] ... strong and sustaining communities," with the input and participation of their citizens. ${ }^{319}$ Thus, the concept of social capital bridges the divide between communitarian theory and practice. ${ }^{320}$

\section{A. All Our Kin}

In 1974, Carol Stack documented in All Our Kin how poor AfricanAmericans in a Midwestern city adapted to poverty by relying upon extensive

supra note 309 , at 52, 54-55. Sharon Hays explains that it is a minority of welfare mothers (perhaps onethird to one-half) who exhibit behaviors that deviate from mainstream norms, and they are not "blind to the stigma attached to their ideas and behaviors, and almost none were without ambivalence about the path of their lives." HAYs, supra note 68 , at 183 . The lives of these mothers "are always a response not just to the material circumstances of life at the bottom but also to the values of the wider society." Id. at 183-84. They represent an "oppositional response" to mainstream culture. Id. at 213 (emphasis omitted).

314. Ann Chih Lin, Interpretive Research for Public Policy, in COPING WITH POVERTY, supra note 309, at 1, 6 [hereinafter Lin, Interpretive Research].

315. Alice O'Connor, Historical Perspectives on Race and Community Revitalization, available at www.aspeninstitute.org/AspenInstitute/files/CCLIBRARYFILES/FILENAME/0000000178/9OConnor.pdf, at 2 (last visited Mar. 6, 2005) ("History from the 'ground-up' is replete with examples of resistance to, as well as political and economic exploitation of, the spatial restrictions of the color line.").

316. Lin, Interpretive Research, supra note 314, at 6.

317. KATZ, supra note 112, at 146-47.

318. Sherman A. James et al., Social Capital, Poverty and Community Health: An Exploration of Linkages, in Social Capital and Poor Communities, supra note 311, at 165.

319. Daly, supra note 36 , at xiv.

320. The concept of social capital is not without its critics. See Alejandro Portes \& Patricia Landolt, Unsolved Mysteries: The Tocqueville Files II: The Downside of Social Capital, АM. РRospect, May-June 1996, at 18 (asserting that inner-city poverty results not from a lack of social capital, but from a lack of economic resources). 
networks of kin and friends who traded goods, resources, and care of children. ${ }^{321}$ In the neighborhood where most African-Americans lived, many residents were unemployed and those who found work were trapped in lowpaid, temporary, and seasonal work. ${ }^{322}$ To cope with poverty, residents adopted a variety of tactics centered on a "domestic web of a large number of kin and friends whom they [could] count on." ${ }^{323}$ In describing these interdependent relationships, Stack rebutted the prevailing wisdom that female-headed homes and illegitimacy "are symptomatic of broken homes and family disorganization." ${ }^{324}$ To the contrary, the community was quite organized; intricate patterns of exchange allowed goods to be "perpetually redistributed among networks of kinsmen and throughout the community." ${ }^{25}$ Although families did not conform to the model of the nuclear family, children were highly valued, and rights in children and obligations to provide for them were shared by networks of cooperating kinsmen in overlapping households. ${ }^{326}$ Women headed families because the conditions of poverty militated against marriage and long-term male-female relationships. ${ }^{327}$ The welfare system cut off benefits to women when they married and strict income requirements precluded individuals from accruing surplus cash for emergencies or equity for long-term stability. ${ }^{328}$ At the same time, employment opportunities for black men were extremely limited, and, if available, low-paid. As a result, "[w]omen [came] to realize that welfare benefits and ties within kin networks provide[d] greater security for them and their children" than marriage. ${ }^{329}$ Thus, Stack showed that rather than

321. Carol Stack, All Our Kin: Strategies For Survival in a Black Community 28, 93 (1974). Stack conducted her ethnographic study by living in the Flats for three years. She found that the kin and non-kin alliances were "so entwined that not to repay on an exchange meant that someone else's child would not eat." Id. at 28.

322. Id. at 23-24. Residents also struggled with substandard and overcrowded housing, and were forced to move frequently due to housing shortages and evictions. Id. at 91-92.

323. Id. at 93.

324. Id. at 44 .

325. Id. at 33 .

326. $I d$. at 89 . Child ren were often raised by kin other than their parents and moved frequently within their kin group. $I d$.

327. Id. at $108,117$.

328. $I d$. at 105,113 . Stack was particularly disheartened by the inability of residents in the Flats to accrue equity or even surplus cash. "Increases in cash are either taken quickly from the poor by the welfare agencies or dissipated through the kin network." Id. at 107.

329. Id. at 113. People who got married often exited the kin networks, and thus, those networks put pressure on individuals not to marry. Id. at 113-14. "Kin regard any marriage as both a risk to the woman and her children and as a threat to the durability of the kin group." Id. at 117 . Men are expected to contribute to the kin network and not dissipate services to a sexual or marital relationship. Id. at 118 . 
disorganized and deviant, "[t]he black urban family, embedded in cooperative domestic exchange, proves to be an organized tenacious, active, lifelong network." ${ }^{\prime 330}$

\section{B. Social Networks in the Face of Welfare Reform}

The challenges facing poor, urban black families today are depressingly similar to those in 1974-high rates of unemployment, low-paid work, substandard housing, and inadequate health care. Not surprisingly, more recent studies have found that today's poor rely on the same sort of tactics documented by Stack to cope with poverty. For instance, a study conducted at the same time as the passage of TANF focused on life in a poor black Midwestern suburb (called by the pseudonym "Meadow View"), where living "is a merciless challenge," scarred by violence, drugs, and constant crisis. ${ }^{331}$ Protecting children in Meadow View from harm is a relentless, emotionallydraining task. ${ }^{332}$ The vigilance parents must exercise is an impediment to working and parenting simultaneously in a community lacking child care and before- and after-school care, ${ }^{333}$ and where children suffer psychological and behavioral problems from the constant stress. ${ }^{334}$ Nevertheless, as "vulnerable families struggle to fulfill each other's needs ... this very exertion reinforces a 'collective ethos' that binds people together." ${ }^{335}$ As a result, families and friends provide survival networks for one another, providing care for children and the elderly, as well as financial assistance. ${ }^{336}$ Work and school are made possible by caregivers who sacrifice their individual pursuits. ${ }^{337}$ This means that "mothers' work is inextricably linked to the nonwork or misfortunes of

330. Id. at 124. "That one can repeatedly join the households of kin is a great source of security among those living in poverty, and they come to depend upon it. The loyalties toward kinsmen offset to some degree, the self-defeating ordeal of unemployment and poverty." Id. at 123.

331. Sharon Hicks-Bartlett, Between a Rock and a Hard Place: The Labyrinth of Working and Parenting in a Poor Community, in CoPING WITH POVERTY, supra note 309, at 27, 28. Hicks-Bartlett notes that Meadow View is a "suburb in name only." $I d$. "[I]t looks like the rural south, with its unpaved roads, two outhouses, and a creek set deep in the woods." Id. at 30. By 1990, the unemployment rate was twentysix percent and just under half the population lived below the poverty level. Id.

332. Id. at 32-33.

333. Hicks-Bartlett notes that the mothers in Meadow View all want quality care for their children. Id. at 40. Middle-class parents can purchase such care, but poor parents cannot. Id. Moreover, programs like Head Start do not serve all needy children, nor do they operate on the off hours of many low-wage jobs. Id. The community also lacks a public library, youth services, or recreation programs. Id. at 47 .

334. Id. at 33-35.

335. Id. at 28 .

336. Id. at 29,35 .

337. Id. at $37,41$. 
other women who may or may not be employed." ${ }^{338}$ It also means that poor families, who cannot purchase child care, must supply it to one another, and accept the level of care that results. ${ }^{339}$ Because care arrangements are complex and tenuous, any small problem, such as a child's illness (and poor children are sicker than others), can snowball into a major crisis and limit a mother's ability to work. ${ }^{340}$ While TANF draws harsh lines between working poor mothers and welfare mothers, the mutual dependence between the two groups in poor communities "makes it impossible to draw moral and ethical distinctions between the two." ${ }^{341}$ No one gets ahead in this environment. Welfare mothers sacrifice their own advancement, while working mothers in Meadow View earn low wages, usually as home health care aides and nursing home workers, and struggle to obtain transportation to jobs, which are located in wealthier suburbs. ${ }^{342}$ In turn, these struggles put stress upon supportive networks. $^{343}$

\section{Robert Taylor Homes and the Politics of Poverty}

Sudhir Allahi Venkatesh has demonstrated how these coping networks in poor communities go beyond kinship circles and can become politicized pockets of resistance. ${ }^{344}$ Venkatesh describes communal life in the infamous Robert Taylor Homes public housing project in Chicago, where, despite immense hardships, residents regularly joined forces to make demands upon city government for needed services, such as law enforcement and property management, to control the behavior of youth, and to otherwise improve their blighted environment. ${ }^{345}$ Built in 1962 to house the city's black residents, the Homes consisted of twenty-eight high rises with 4,500 units, surrounded by vast acres of concrete and asphalt that physically isolated the Homes from the rest of Chicago. ${ }^{346}$ From the start, residents organized both informally, to

338. Id. at 48 .

339. Id. at 37-40. "Custodial care performed by caregivers with limited skills, poor health, little knowledge of normal child development, and unsafe homes creates anxiety for working mothers." Id. at

40. At the same time, it is often the only option. $I d$.

340. Id. at 37.

341. Id. at 40 .

342. Id. at 43 .

343. Id. at 48 . (2000).

344. Sudhir Alladi Venkatesh, American Project: The Rise and Fall of a Modern Ghetto

345. Id. at 9, 275-76.

346. Id. at $15-21$ 
monitor the behavior of children in an environment almost totally devoid of usable play space, and formally, through democratically elected tenant councils that demanded upkeep of the quickly deteriorating properties from the city's often corrupt housing authority. ${ }^{347}$ By the 1970s, unemployment, the school drop-out rate, and welfare reliance increased. ${ }^{348}$ At the same time, the physical structures were falling apart, crime and vandalism began to rise, and the city had less money to spend on tackling problems at the housing project. $^{349}$ Tenants responded to these pressures by engaging in a vigorous underground economy and by establishing indigenous law enforcement mechanisms founded on tenant patrols and community watches. ${ }^{350}$ However, these efforts were overwhelmed by increasing hardships and neglect from broader society. ${ }^{351}$

The rise of drug gangs in the 1980s, accompanied by a steep drop in federal funding as well as mismanagement and scandal at the Housing Authority, severely challenged the ability of tenants at the Robert Taylor Homes to control their environment. ${ }^{352}$ During this time, crime, violence, and vandalism rose, as did tenant drug use. Gangs interfered with the networks and associations that supported the underground economy, ${ }^{353}$ and they intimidated tenant leaders into silence. In the 1990s, tenants cautiously began to fight back. They demanded increased responsiveness from police, on the issue of gangs as well as problems with domestic violence and theft. A community center had some limited success in mediating gang conflicts, but it aligned itself too closely with gang leaders. A deep division and rigorous debate arose among the tenants as to whether to respond to gang violence by working with gangs or by disassociating from them. In 1994, the tenants elected a resident leader who advocated the latter route. ${ }^{354}$ "They did so not as a disorganized community, but in a way that revealed the presence of a

347. Id. at 23-24, 29-32, 63.

348. Id. at 65 .

349. Id. at 66 .

350. In a time of increasing stress, there was nevertheless "sharing between families ... [and also] brokerage relationships of police and tenants, residents' creative self-policing techniques, and the underground activity that tenants drew upon to acquire goods and services." Id. at 105.

351. Id. at 275 .

352. Id. at 148 . The federal government cut the Housing Authority's budget by eighty-seven percent in the 1980s. Id. The federal government eventually took over the housing authority. Id.

353. Id. at 150 .

354. Id. at 261 . 
healthy, normative foundation amid deeply rooted economic impoverishment." ${ }^{355}$

Tenant resilience, however, was not enough to save the Robert Taylor Homes in the face of law enforcement that refused to secure the development, federal cuts in funding for public housing, massive job losses in the inner-city that resulted in $90 \%$ unemployment at the Homes, housing discrimination against families who tried to move out, lack of municipal support, and other institutional neglect from society at large. ${ }^{356}$ As of 2004, most of the Robert Taylor Homes have been demolished pursuant to the federal HOPE VI program, ${ }^{357}$ and the remainder will come down in 2005. The high-rises will be replaced by 2,388 mixed-income rental and homeownership units, of which 851 will be public housing units. ${ }^{358}$ In reflecting upon the plight of the Homes, Venkatesh accuses Americans of asking "more of the poor, and particularly those in public housing, than we expect from other citizens,",359 and he queries whether the communal bonds between tenants could have resulted in greater successes if they had had government support committed to economic development. ${ }^{360} \mathrm{He}$ concludes that "the difficulties faced by residents of Robert Taylor in every period of its existence can be seen as a result not of behavioral pathology but of institutional neglect." ${ }^{361}$ He marvels that despite this neglect, the tenants demonstrated "impressive efforts to cope and make life meaningful amid a dearth of resources." 362

\section{Dudley Street Neighborhood Initiative and the Triumph of Community}

By contrast, there are blighted neighborhoods that have pulled themselves back from the brink of ruin with the sort of support that was so sorely lacking at the Robert Taylor Homes. One prominent example is the revitalization of the Dudley Street neighborhood in Boston. The comparison of the economic

355. Id.

356. Id. at $270-74$.

357. For an excellent discussion of HOPE VI, see Ngai Pindell, Is There Hope for HOPE VI: Community Economic Development and Localism, 35 ConN. L. REv. 385 (2003).

358. See the website of the Chicago Housing Authority, available at http://thecha.org/housingdev/ robert_taylor.html (last visited Mar. 6, 2005).

359. VeNKATESH, supra note 344, at 273.

360. Id. at 275 .

361. Id. at 274 .

362. Id. A similar study of other public housing developments in Chicago paints a bleaker picture of tenant cohesion, but also highlights examples of tenant resistance and response to institutional neglect. Susan J. Popk in et al., The Hidden War: Crime and the Tragedy of Public Housing in Chicago 50-51, 57, 80-81, 150-52, 158-61, 178-79 (2000). 
and social development within Dudley Street with the ruin of the Robert Taylor Homes is instructive. Located on 1.5 square miles less than two miles from downtown Boston, ${ }^{363}$ the Dudley Street neighborhood has long been one of the poorest neighborhoods in Boston. ${ }^{364}$ The per capita income in the neighborhood of 24,000 people is less than half that for the City of Boston overall, unemployment hovers at $16 \%$, and $32 \%$ of the residents live below the poverty line. ${ }^{365}$ Nevertheless, the diverse, multicultural neighborhood has a thriving and ambitious resident-controlled community organization of 8,000 members with political and social clout that has garnered tangible development results, ranging from 400 new affordable houses to environmental clean-up to new community-based schools. ${ }^{366}$

In the 1950s, disinvestment, redlining, property abandonment, and insurance-related arson turned the once-thriving neighborhood into a wasteland. ${ }^{367}$ By 1981, one-third of the land within the neighborhood was vacant, and the neighborhood had become an illegal dumping ground for trash from all over Boston. ${ }^{368}$ In 1984, a local philanthropic foundation approached a Hispanic social service non-profit within the neighborhood to discuss possibilities for neighborhood improvement. ${ }^{369}$ From this early collaboration, a grassroots community organization, called the Dudley Street Neighborhood Initiative (DSNI), was founded with the goal of resisting a city plan proposed by the Boston Redevelopment Authority that threatened resident displacement through gentrification. ${ }^{370}$ At an early meeting, over 200 residents attended and demanded increased participation on the DSNI board. ${ }^{371}$ In response, the organization went from being controlled by local non-profits to an entity with a majority of board seats committed to residents, and with equal minimum

363. BRIGHT, supra note 311 , at 76 . Prior to World War II, the neighborhood consisted of mostly Irish and Italian working class immigrants. $I d$. In the 1960 s and 1970 s, the minority population increased dramatically as European-Americans fled the city in the face of riots and court-ordered school busing. Id. at 77 .

364. See the home page of the Dudley Street Neighborhood Initiative, available at http://www.dsni. org (last visited Mar. 6, 2005).

365. Id.

366. See BRIght, supra note 311 , at 78-93. This compelling story is told in the documentary, Holding Ground: The Rebirth of Dudley Street (Holding Ground Productions 1997).

367. Peter Medoff \& Holly Sklar, Streets of Hope: The Fall and Rise of an Urban NEIGHBORHOOD 2 (1994); see also BRIGHT, supra note 311, at 77 (stating that more than twenty percent of the neighborhood was burned down by arsonists in the 1960s).

368. Medoff \& SKLAR, supra note 367, at 2.

369. BRIGHT, supra note 311, at 78.

370. MEdofF \& SKLAR, supra note 367 , at 37-52.

371. Id. at $52-56$ 
representation for the four main cultural groups in the neighborhood (AfricanAmerican, Cape Verdean, Latino, and white). ${ }^{372}$ The foundation provided $\$ 70,000$ in start up funds, despite its loss of direct control over DSNI's activities. $^{373}$

From the start, DSNI aimed to balance short-term victories with long-term plans for redevelopment, with both strategies hinging on community organizing. ${ }^{374}$ Based on a survey of resident priorities, DSNI organized a "Don't Dump on Us" campaign to clean up and fence off vacant lots (of which there were 1,300) and to communicate sanitation complaints to city officials. ${ }^{375}$ Their demands eventually caught the attention of Mayor Raymond Flynn, who, eager to shore up support in minority communities, showed up at a community meeting and pledged city support for the DSNI clean-up effort. ${ }^{376}$ The city provided materials and tools that residents used in a massive clean-up effort. Shortly thereafter, DSNI staged a public demonstration, widely covered by the media, to stop illegal trash transfer stations and their accompanying stench and noise. ${ }^{377}$ The city again responded, padlocking the illegal transfer stations and prosecuting the dumpers in court. From these early victories, residents became galvanized to take on larger projects. ${ }^{378}$

With the help of foundation-funded consultants, DSNI turned its attention to long-range planning. It developed a comprehensive, 200-page master plan for redevelopment of the community that addressed land use, housing, human services, economic development, and employment. The plan relied extensively on community input and proposed an urban village, with a vibrant mix of housing, shopping, open space, and a community center. ${ }^{379}$ The city adopted the plan as the official redevelopment plan for the area. ${ }^{380}$ One obstacle to effectuating the plan was that over half of the land in the heart of

372. Id. at 56-57.

373. BRIGHT, supra note 311 , at 79 (describing the donation as "a supportive action rarely seen in philanthropic circles").

374. See Bright, supra note 311, at 79 ("By setting achievable goals, DSNI kept the level of participation high . ..."); MEdOFF \& SKLAR, supra note 367, at 67-69.

375. See Medoff \& Sklar, supra note 367 , at 70-72.

376. See BRIght, supra note 311 , at 80.

377. See Medoff \& SkLAR, supra note 367 , at 83-84.

378. See BRIGHT, supra note 311 , at 80 .

379. See BRIGHT, supra note 311 , at 81 (noting that over 150 residents helped shape the plan over eight months of trilingual meetings); Medoff \& SKLAR, supra note 367, at 105; Simon, supra note 297, at 115 (noting that DSNI spends great "time and resources to help community participants understand the issues and options involved in its projects").

380. See BRIGHT, supra note 311 , at 81 . 
the neighborhood consisted of a patchwork of city-owned and privately-owned vacant and abandoned property. ${ }^{381}$ The city gave DSNI the city-owned lots along with eminent domain power over the privately held lots, making DSNI the first grassroots community organization in the country to receive eminent domain power. ${ }^{382}$ The purchase of the properties was financed largely through a $\$ 2$ million investment by the Ford Foundation. ${ }^{383}$ In 1993, thirty-eight affordable single-family homes were completed, and other achievements have continued to follow, including more affordable housing (350 new homes), new neighborhood associations and gardens, a Town Common, urban agriculture, parks and playgrounds, youth programs and a summer camp, better mass transit, and more human service providers. ${ }^{384}$ DSNI has also established a network of family day care providers, there is an adult education program for high school dropouts, and a multicultural festival is held annually. ${ }^{385}$

\section{E. Lessons Learned from Poor, Urban Communities}

These brief case studies lend empirical support to various aspects of communitarianism. ${ }^{386}$ Communitarianism is in part an attack on atomism, or the notion that individuals do and/or should selfishly pursue their own interests. The poor communities discussed above reveal the degree to which their residents are socially constituted by their surroundings and limited in their ability to pursue autonomous ends. In addition, communitarians such as Walzer stress communities as a source of values that should be respected.

381. Fifteen acres of vacant land were owned by the city of Boston, while fifteen acres were privately held. See Medoff \& Sklar, supra note 367, at 117.

382. See id. at 119 . The power is exercised through a community land trust set up by DSNI. The grant of eminent domain power went through four years of legal challenges, but was ultimately upheld. BRIGHT, supra note 311 , at 82 . "It is a noteworthy but somewhat ironic accomplishment that this community has taken the tactics — eminent domain, land trusts, and restrictive covenants — which have been used for years to evict the poor, keep vacant lands unused and segregate affluent neighborhoods, and employed them to accomplish opposite goals." See id. at 83.

383. See id. at 84.

384. See BRIGHT, supra note 311, at 85-86, 93; MEdofF \& SKLAR, supra note 367, at 253.

385. See BRIGHT, supra note 311 , at 86-87. The neighborhood continues to struggle with high rates of poverty, a lack of mainstream financial institutions, environmental contamination, and trash covered vacant lots outside of DSNI's eminent domain power. $I d$. at 92 . Yet, the residents remain optimistic about long run success, as one member said, the neighborhood “'didn't take two years to get this way ... it took 20 to 30 years, and it may take 20 to 30 years to correct." Id .

386. Stephen Gardbaum untangles the various claims about community that are made by communitarians. He explains that there are three independent ideas lumped together under the communitarian heading; community refers to the constitution of personal identity, the source of binding values, and a substantive notion of the human good. See Gardbaum, supra note 49, at 690-92. 
These case studies illustrate that the value structures in poor communities are far more complex than usually assumed and that the potential for transformation is much greater. Alternatively, communitarians such as Sandel stress community as a value in arguing for republicanism, and these case studies confirm the importance of political community in combating conditions of poverty.

As a policy matter, the case studies suggest several lessons, each of which is consistent with certain aspects of communitarian theory. First, the case studies suggest that rather than increasing isolation, economic deprivation causes people to turn to one another for support. Indeed, physical decay within distressed communities does not always signal a lack of capacity by residents. ${ }^{387}$ Communitarianism is concerned with fostering communal associations, ${ }^{388}$ and those already exist to varying degrees within distressed communities. Accordingly, policymakers should build upon existing social structures rather than simply focusing on reforming individuals.

Second, the case studies demonstrate that while social capital exists in even the most distressed neighborhoods, residents cannot meaningfully capitalize on their social assets without significant support from outside institutions, such as government at all levels, the non-profit sector, and private businesses. $^{389}$ Although communitarians have been frustratingly vague on how and at what level they define community, they all seem to leave room for multiple layers of community. Etzioni probably articulates this most clearly, explaining that "[c]ommunities are best viewed as if they were Chinese nesting boxes, in which less encompassing communities (families, neighborhoods) are nestled within more encompassing ones (local villages and towns), which in turn are situated within still more encompassing communities, the national and cross-national ones ...."390 This conception of membership in multiple and layered communities suggests that it is fair and

387. Bennett, supra note 312 , at 306.

388. Communitarians want to establish "in the public domain the values of communal associations." Daly, supra note 36 , at xiii.

389. "The experience of CDCs has shown that the partnership of representative neighborhood organizations and city government, with support from private corporations, philanthropic intermediaries, and state and federal government, can provide a basis for successful neighborhood revitalization efforts, even in the poorest of neighborhoods." W. Dennis Keating ET AL., Revitalizing Urban NeighBorhoods 4 (1996). See also Bright, supra note 311, at 99-101 (noting importance of support from wide "variety of agencies at levels of government, private foundations, and service providers outside the neighborhood"). The legal community was another key component of DSNI's successes. Private firms donated \$1 million worth of assistance. Id. at 100 .

390. Etzioni, Spirit of Community, supra note 1, at 32. 
just to call on all Americans to contribute to the alleviation of poverty, because all Americans are part of a national community with mutual obligations to one another.

Third, these examples show that holistic approaches that treat social problems in a comprehensive manner yield greater success than piecemeal, ad hoc approaches - a proposition that seems obvious, but one that has not shaped public policy. Likewise, the interwoven involuntary connections stressed by communitarian thinkers also point to the need for an understanding of the complex nature of communal groupings and a corresponding acknowledgment of the multi-faceted strategies that are called for in combating social problems.

Finally, the case studies show that communities that exercise control over, and have a voice in, their own destiny achieve greater successes than those subject to outside direction. ${ }^{391}$ With regard to DSNI, the single most important factor in its success was resident control. ${ }^{392}$ This outcome supports the communitarian emphasis on civic participation. In building upon social capital, our welfare policy would be well-served to take these lessons into account.

\section{A Community-Based Welfare System}

Obviously, there are countless alternatives in creating a welfare system, and TANF is only our most recent attempt to balance the tension between supporting the needy and discouraging dependence. At one extreme, we could have no cash or other material assistance for the poor, as Charles Murray and other political conservatives have advocated. Communitarians do not appear to support this option, because they recognize that strong communities and able citizens cannot flourish in the face of extreme deprivation. Thus, although communitarians fret about creating dependency, none of them have advocated for total elimination of the social safety net. At the other extreme, we could implement either a fully liberal or fully communitarian remedy. A

391. Keating ET AL., supra note 389 , at 4.

The collective experience of more than three decades has demonstrated that, although citizen participation is likely to be limited and hardly a panacea for urban problems, nevertheless, the residents of urban neighborhoods must be actively engaged to make urban policies and programs work effectively and serve the interests of the urban neighborhoods for which they are intended. Id.

392. BRIGHT, supra note 311 , at 101 . "The cooperation has lead to the creation of a 'village' atmosphere, including social infrastructure and support networks which are of primary importance to many residents." Id. 
fully liberal, progressive approach would likely provide all needy persons, regardless of the reason for their need, with no-strings-attached cash assistance designed to bring them to a meaningful level of self-sufficiency. This is a liberal solution to poverty because it is value neutral, and it enhances the autonomy of recipients. By contrast, a fully progressive, communitarian approach would pump massive resources into poor communities and integrate policies related to housing, economic development, physical and mental health care, public safety, and education into a coordinated and seamless web that would maximize the social capital of these neighborhoods so that each resident could participate in and benefit from civic involvement.

As a nation, we are nowhere near implementing either the extreme liberal or communitarian solutions. To the contrary, TANF reflects collective values that demand individual responses to societally-created problems, and thus combines almost the worst that liberalism and communitarianism have to offer the poor. Accordingly, this Part seeks to re-conceptualize TANF in a realistic and pragmatic way that builds upon communal strengths to obtain better individual and neighborhood outcomes. The idea here is not to replace the individual as the locus of welfare support, but rather to enhance individual outcomes by taking into account and enhancing the social context in which individuals live. I describe this approach as "community-based" rather than communitarian, because communitarianism has so marginalized issues of poverty that it would require significant conjecture to articulate where communitarians would go if they started from accurate premises concerning the causes of poverty. Nevertheless, communitarian philosophy aids this project because, at its most progressive, it provides a foundation for moving away from individual blame and towards understanding of the root causes of poverty, and eventually, to collective responsibility for alleviating economic disadvantage. It values the positive aspects of community, and in turn, the value of nurturing community, and in so doing, it can highlight and draw upon the substantial reserves of social capital within poor neighborhoods despite the profound problems they face. At the same time, communitarianism can be highly moralistic and judgmental, and this conservative strain of communitarianism demands caution when discussing the poor. This Part first addresses how welfare could cultivate community participation and activism. It then proposes community-based approaches for overcoming the barriers to work and self-sufficiency faced by TANF recipients. Notably, many of these approaches are among the policy options states can adopt in spending TANF dollars, and thus, do not require new legislation at the federal level. However, in light of TANF's work-first emphasis, few of the community-based options are being pursued in any systematic way because they require more time and 
expertise than putting people to work in low-wage jobs. Accordingly, federal mandates that require the states to engage in community-based planning would likely be necessary to truly effectuate these policy choices. Finally, this Part considers the moral values that a welfare system should pursue.

\section{A. Community Participation}

Sheryll Cashin has argued that the devolution of welfare policy from the federal government to the states results in policies that undermine the Act's stated goals of assisting and strengthening families. She contends that voters punish state legislators more than federal lawmakers for increases in welfare spending and that state legislators are more likely to be influenced by negative and racist stereotypes of welfare recipients. ${ }^{393}$ In light of the "inexorable influence of middle class suburban voters on state policy choices, and the consequent marginalization of low-income and urban-interest groups," ${ }^{394}$ Cashin argues that fundamental policy choices about welfare are best made at the national level. ${ }^{395}$ Cashin presents a convincing case, and indeed, has been proven correct. States with the highest minority populations have adopted the most punitive and stringent welfare policies. This is undoubtedly the dark side of devolution.

Nevertheless, devolution may have an untapped upside by providing increased opportunities and sites for citizen participation that could be utilized as a counter-balance to the negative aspects of welfare federalism. Devolution has been accompanied by an increase in privatization of welfare administration and related social services, which are being provided by a mix of for-profit, non-profit, and religious organizations. At the same time, frontline workers exercise vastly more discretion than they did under AFDC, as they devise work plans tailored to individual needs and have the power to sanction individuals who do not comply with program requirements. This transfer of governmental authority to private entities raises profound concerns about accountability. As a legal matter, doctrines that constrain the discretion of government actors, such as the Due Process Clause and federal and state Administrative Procedure Acts, generally do not apply to private actors. As a practical matter, the empirical evidence shows that governments are doing an inept job at monitoring welfare contracts, and the services provided are so

393. Cashin, supra note 257 , at 582-83.

394. Id. at 583.

395. Id. at 615-22. 
complex that measuring outcomes is exceedingly difficult. ${ }^{396}$ Moreover, a major study of neighborhood-based organizations that deliver welfare-related services has found that TANF is having a deleterious effect by contributing to the "balkanization of community-based organizations and ignor[ing] the importance of civic participation and the building of social capital." ${ }^{, 397}$ In addition, these organizations are "being transformed rapidly from helping and assistance organizations to monitoring mechanisms for the state's watching of poor people." ${ }^{, 398}$ Citizen participation is one way to fill this accountability gap.

For instance, local governments could set up formal mechanisms within procurement processes to work with residents of low-income neighborhoods to identify needed social services, to determine whether private provision is appropriate, to draft requests for proposals, to identify points for negotiation, to select final bids, to gather feedback on program effectiveness, and to determine whether to renew or cancel existing contracts. In addition, governments could require that welfare service providers have community representatives on their boards of directors and a certain proportion of community members on their staffs. Community participation would serve instrumental ends, by providing government with accurate information about community needs and program effectiveness. In addition, it would serve liberal ends by providing people with opportunities for self-transformation that could heighten their autonomy as they seize greater control over their environments. Community participation also serves communitarian ends by making more engaged citizens and by educating citizens to participate not only in direct democracy, but also in representative democracy and the political process. Finally, community participation has the potential to empower entire communities, and not just individuals, as long as communities have a meaningful voice in and measure of control over the decision-making process.

Yet, it is not easy to design effective citizen participation mechanisms, a factor that Sandel blithely ignores. ${ }^{399}$ While federal mandates for citizen

396. See Gilman, Charitable Choice, supra note 78, at 847-51.

397. See Jennings, supra note 194, at 1.

398. Id. at 44. Neighborhood-based organizations also complain of misinformation and lack of information from state administrators about welfare reform rules and policies. Id. at 44-46, 58. See also Ann Withorn, Friends or Foes? Nonprofits and the Puzzle of Welfare Reform, AM. Acad. Pol. \& Soc. SCI., 577 ANNALS 107, 108 (Sept. 2001) (stating that welfare reform has negatively impacted ability of nonprofits to be "active players in efforts for economic and social justice").

399. Citizen participation mechanisms can fail to reconcile competing interests, can marginalize persons who speak differently or not at all, and can slow down decision-making processes. See Audrey G. McFarlane, When Inclusion Leads to Exclusion: The Uncharted Terrain of Community Participation in 
participation have no history in welfare programs, they have a long and checkered history in anti-poverty economic development and housing programs. Audrey McFarlane has explained that, in the realm of economic development, there is an inherent and unresolved tension between the elite, expert-driven process of development and the "views of a collection of nonprofessional, non-expert, and potentially disruptive citizens. ${ }^{.400}$ In the major federal economic development program currently underway, Empowerment Zones, McFarlane finds that communities have been pushed aside or relegated to decision-making over peripheral issues because the program and its various constituents are not clear on the goals of community participation. ${ }^{401}$ Moreover, allowing residents to exercise control over substantive decisionmaking in economic development threatens to undermine fundamental determinations about resource allocation that are made without community input.

In the context of public housing, Susan Bennett has explained that federal programs that fund and foster resident management of housing projects have led to some level of personal self-transformation for trainees, but have also suffered from attrition over time. ${ }^{402}$ "Not all residents want to become involved in the nitty gritty of property management; conversely, residents consumed with the details of property management may have no time, or inclination, for democratic process. ${ }^{403}$ Obviously, citizen participation in welfare poses similar challenges; people who are struggling to survive may have little time or inclination for participating in meetings and forums designed to elicit their input. Bennett notes that most recently, as a result of TANF, current public housing policies now focus on individual self sufficiency rather than community building. ${ }^{404}$ Moreover, in the federal HOPE VI program, which gives grants to cities to demolish high-rise public housing projects and replace them with mixed-income developments, public housing residents have a "voice" in the redevelopment, but no "say" to affect the ultimate outcomes. ${ }^{405}$

Economic Development, 66 Brook. L. Rev. 861, 913-16 (2001).

400. See id. at 864 .

401. See id. at $890-92$.

402. Bennett, supra note 312.

403. Id. at 298 .

404. See id. at 281,291 . The budgetary cuts to public housing programs have "elevated the strain in the program that delivered social services to individuals over that which built capacity for the collective." Id. at 294

405. In discussing the frustrations of representing community groups, Susan Bennett states, "[e]xamples abound of processes which seem to invite participation by community residents or community 
Accordingly, for citizen participation mechanisms to have any impact in a welfare system, government needs to share decision-making power with community groups, and the community needs enforcement mechanisms to ensure that participation occurs. ${ }^{406}$ The goal of community participation needs to be conceptualized as not only "participatory inclusion, but also as a struggle for redistribution of power." ${ }^{\text {"407 }}$ Accordingly, some welfare funds should go towards programs that build the capacity of neighborhood groups and train residents in the basics of organizational development, as well as community organizing. Government also needs to make participation feasible, by meeting during non-work hours, holding meetings in neighborhoods or providing transportation, offering child care during meetings, and the like. In other words, participation needs to lead to results, and government needs to lay the foundation for this to happen, even though this might engender conflict with government.

\section{B. Barriers to Work}

Communitarians support the idea of requiring work as a condition for receiving welfare, because work accords with communitarian notions of reciprocity and because they view work as enhancing dignity and cultivating the values that make good citizens. ${ }^{408}$ Yet, "work" can hold a variety of meanings. For instance, does "work" include caring for dependents such as children, the disabled, and the elderly? Does it include government-created jobs if work is not available in the economy? Does it include job training and education that can lead to better opportunities? TANF has generally answered "no" to these questions, but communitarians have not engaged in meaningful deliberation on the meaning of work. Communitarianism stresses norms of reciprocity and mutual obligation. Indeed, these norms are the underlying supports for successful communities, which "contain elements such as local friendship ties, social cohesion, resident participation in formal and informal voluntary organizations, stability of formal organizations, and informal social

groups, but which either deliberately or mindlessly eliminate any real opportunity for them to affect any outcomes." Susan D. Bennett, Little Engines that Could: Community Clients, Their Lawyers, and Training in the Arts of Democracy, 2002 Wis. L. Rev. 469, 470 (2002).

406. See McFarlane, supra note 399, at 929-30.

407. Id. at 929 .

408. Likewise, some feminists have favored work because it provides dignity by linking women to larger societal structures. See Vicki Schultz, Life's Work, 100 Colum. L. Rev. 1881 (2002) (arguing for the significance of paid work to the good life). 
controls." ${ }^{409}$ Yet, reciprocity suggests an even exchange, while TANF is woefully one-sided. Welfare recipients must work, but, in return, they are not guaranteed meaningful work, full-time work, adequate supports that make work possible, a living wage, or the ability to be truly self-sufficient as an economic matter. True reciprocity would correct these disparities.

\section{Child Care}

Without adequate child care, it is impossible for a welfare recipient to meet TANF's stringent work requirements. Nevertheless, child care remains out of reach for thousands of TANF recipients who struggle to satisfy both work and parenting obligations. Only one of out every seven children who is federally eligible for a TANF child care subsidy is receiving assistance, ${ }^{410}$ because TANF does not provide enough money to extend child care benefits to all who need it. ${ }^{411}$ Moreover, due to federal funding limitations, some states are attempting to ration available subsidies with tactics such as lowering income eligibility levels, limiting outreach efforts, creating waiting lists, and utilizing complex and burdensome application procedures. ${ }^{412}$ Without a subsidy, a single mother earning the minimum wage must spend half of her pre-tax income to pay the average cost of child care. ${ }^{413}$ Furthermore, this assumes that day care slots are actually available, when, in reality, there is a shortage of child care and an increasing number of women are working non-

409. WiLSON, supra note 121, at 20.

410. See Jennifer Mezey et al., Reversing Direction on Welfare Reform: President's Budget Cuts Child Care for More than 300,000 Children, Center on Budget \& Pol'y Priorities (Ctr. for Law \& Soc. Policy), Feb. 10, 2004. See also Gina Adams \& Monica Rohacek, Child Care and Welfare Reform, in The NeXt Act, supra note 85, at 128 . Only fifteen to thirty percent of federally eligible children are receiving subsidies. See Mildred Warner et al., Addressing the Affordability Gap: Framing Child Care as Economic Development, 12 J. Affordable Housing \& Community Dev. L. 294, 297 (2003).

411. TANF appropriated substantially more money for child care than prior programs, and, at the same time, gave the states substantial discretion in determining whether and how to award child care subsidies. See Adams \& Rohacek, supra note 410, at 124. Almost all states are spending some TANF funds for child care, and are using their own funds as well. See id. at 125; Jan Kaplan, Child Care Funding and Policy Issues, 2 Reauthorization Notes (TANF Reauthorization Rescue), No. 1, Jan. 2002, availableat $\mathrm{http}: / / \mathrm{www}$.welfareinfo.org/childcarefundingpolicyissues_trn.htm. Most states provide parents with vouchers to use on the private child care market, and parents make co-payments depending on their income. See Adams \& Rohacek, supra note 410, at 126 . However, policies among the states vary dramatically; some have expanded access to child care, while others have narrowed access. See id. at 127.

412. Id. at 129-30 (reporting that in March 2000, 47 states set eligibility limits below the federal level and that in 22 states a family of three earning $\$ 25,000$ was ineligible for benefits).

413. Susan Traub, Note, Child Care and PRWORA: Paying the Babysitter or Investing in Early Education?, 9 Geo. J. on Poverty L. \& Pol'y 249, 252 (2002). 
traditional schedules during hours for which there are no child care providers. With or without subsidies, many children are receiving low-quality child care, despite reams of evidence that quality child-care is directly related to children's long- and short-term development. ${ }^{414}$ The high cost of child care leads many low-income families to rely on relatives to provide care, ${ }^{415}$ even though these unregulated home settings have lower developmental quality than other providers. ${ }^{416}$ At the same time, the relatives who provide this care are uncompensated for the work they do. Children are also being left unattended. Additionally, many parents fear losing personal supervision over their children in dangerous neighborhoods, and lack the supports that wealthier parents have to ensure their children's safety. ${ }^{417}$ Because TANF emphasizes work outside the home over the well-being of children and their parents, it "demands that parents dichotomize: either they become selfsufficient by putting work first and children last, or they suffer extreme poverty. ${ }^{4} 18$

Communitarianism provides little theoretical assistance to poor women who must navigate the competing goals of work and family. When communitarians address work and family conflicts at all, they tend to do so in the context of middle-class married women. For instance, Sandel is concerned about the fate of middle-class divorcees who chose to be homemakers during their marriages. Etzioni wants parents to put aside their selfish professional aspirations in order to spend more time with their children. Although Walzer acknowledges that women have traditionally performed the "hard work" of the household while being excluded from professional spheres, he disapproves of the impersonality of day care, and urges parents to share child care responsibilities - thereby assuming the existence of a two-parent family. At the same time, when the discussion is about low-income women,

414. Adams \& Rohacek, supra note 410 , at 131.

415. See id. at 132 (noting that twenty-nine percent of subsidized children are in unregulated settings).

416. See Jeffrey A. Capizzano \& Gina Adams, Children in Low Income Families are Less Likely to be in Center Based Care, Snapshots of Am. Fams. III (Urban Institute), 2003; Rebekah B. Levine Coley et al., Child Care in the Era of Welfare Reform: Quality, Choices, and Preferences, Welfare, Child. \& Fams: A Three-City Study (Welfare, Children \& Families Study, Johns Hopkins University), 2001, at 5 .

417. See Hicks-Bartlett, supra note 331, at 47.

418. Karen Syma Czapanskiy, Parents, Children, and Work-First Welfare Reform: Where is the C in TANF?, 61 MD. L. REv. 308, 314 (2002). Czapanskiy states, "Work-first welfare reform, for most states and most families, has focused only on [work]. It has not involved a particularized analysis of the child's condition, the strength of the parent-child bond, or of the family-friendliness of employers and the community." Id. at 313 . 
communitarians are eager to put them to work with little acknowledgment of their parenting obligations.

Feminist thinkers are light years ahead of communitarians in considering the dilemmas posed by care work. To communitarians and liberals alike, dependency is an undesirable condition. Yet, as Martha Fineman has demonstrated, dependency is an inevitable condition. All of us are dependent at some point in our lives, beginning with infancy and re-emerging at times of illness, disability, or old age. Nevertheless, the women who provide care to dependents are either unpaid or low-paid, while society reaps a massive subsidy from their efforts. ${ }^{419}$ The reality of dependency stands in stark contrast to TANF's assumption that "'a working mother as role model is more important for poor children than whatever they might gain from a homebound but publicly supported mother." "420 It also contrasts with the ideal of the individual posited by liberalism and reflected in our workplace, which views "the American worker [as] an unencumbered individual, free to participate in an inflexible nine-to-five schedule without concern for ill children, school vacations, or other caretaking glitches because some woman is taking care of all that at home, for free." ${ }^{21}$

There is a rich feminist literature on how to resolve the tension between work and care while simultaneously valuing the work of care, with proposals that include reforming the workplace to accommodate the demands of parenting, improving conditions within the low-wage workplace, reimagining the balance of power within families, and commodifying unpaid care work. ${ }^{422}$ These approaches are not inconsistent with communitarianism, even if communitarians have largely ignored the care work dilemma. Linda McLain has explained how "recogniz[ing] care as a public value worthy of societal and governmental support" is consistent with civic republican norms, because care

419. Martha Fineman, The Inevitability of Dependency and the Politics of Subsidy, 9 STAN. L. \& POL'y Rev. 89, 90, 92 (1998) (noting that dependency is an "inevitable part of the human condition").

420. Carol Sanger, Separating From Children, 96 Colum. L. Rev. 375, 498-99 (1996).

421. Fineman, supra note 419, at 96 . The liberal individual's "position in the social and economic hierarchy remains essentially unaffected by existing allocations of societal privileges and benefits or by burdens imposed by racism, sexism, or ideologies of family responsibility, or cultural norms." Id. at 90 . See also Robin West, Re-Imagining Justice, 14 YALE J.L. \& Feminism 333, 339 (2002) ("The dominant conception of rights stands as a serious obstacle to the nascent feminist efforts now underway by a number of feminist legal theorists" to construct rights of care. "The 'rights of care' that are needed by caregivers are needed not so much to protect individualistic, heroic, independent acts of will. Rather, they are needed to protect vulnerabilities brought on by our relationality, our mutual dependency, and our interdependency.").

422. These various approaches are ably summarized in Kerry L. Quinn, Note, Mommy Dearest: The Focus on the Family in Legal Feminism, 37 HARV. C.R.-C.L. L. REV. 447, 451-58 (2002). 
relationships are the foundation upon which skills for self-government are built, or, as Sandel puts it, "seedbeds for civic virtue." is also consistent with Walzer's egalitarianism; he urges all members of society to share in its hard work, or at least to value and compensate it highly. ${ }^{424}$ Thus, to truly value care work, we should be subsidizing child care, raising the wages of child care workers, ensuring quality standards in child care centers, and expanding tax credits for parents who stay home to take care of their children. ${ }^{425}$ At the same time, we should be reforming the workplace to support parenting by providing paid family leave, flexible hours, and living wages. These are not welfare-specific solutions; rather, they are needed by all parents.

With regard to welfare specifically, there are several ways in which TANF could build upon existing patterns of social cooperation within poor communities to help in alleviating the child care crisis. To begin with, governments could train, support, and compensate the thousands of women who are currently unpaid child care workers for other mothers' children. Indeed, it makes sense to emphasize child care work as a viable and meaningful career for mothers transitioning from TANF. A handful of programs are training women to provide quality child care either in homebased centers or established centers. Obviously, the benefits of this approach, if done properly, are that it meets a community-based need, it promotes strong parenting skills, it improves the quality of child care, and it enhances employment opportunities. ${ }^{426}$ This approach is not without its share of criticism, however, starting with the fact that child care work is low-paid. Moreover, pushing single mothers into child care reinforces gendered notions of caretaking and can exploit the caretaking work of low-income women. ${ }^{427}$ Yet, poor women are already doing this work for no pay; a paid regime would legitimize the work that they perform and move us a bit closer to the goal of publicly valuing care work. Moreover, child care training programs can be structured to reduce some of these concerns. For instance, one small but successful program in Washington state uses a comprehensive career

423. Linda McClain, Care as a Public Value, Linking Responsibility, Resources, and Republicanism, 76 Chi.-Kent L. Rev. 1673, 1677, 1688-90 (2001).

424. WALZER, supra note 12, at 165-83.

425. Perhaps the ultimate expression of public value for care work would be to pay women - poor and non-poor alike - to provide dependent care if they choose to do so. Eva Feder Kittay has articulated such a vision of “doulia” care. Eva Feder Kittay, Love's Labor 132-33 (1999).

426. See Angela Hooton, From Welfare Recipient to Childcare Workers: Balancing Work and Family Under TANF, 12 Tex. J. WoMEN \& L. 121, 143-48 (2002).

427. See id. at 148-59. 
advancement model in which women receive substantial raises as they attain various educational goals, thus improving pay and professionalizing the field. ${ }^{428}$ Other programs fund non-profits to provide support and training to home based child care providers in both child care and the essentials of running a small business.

Given that many women are in part-time, contingent, and off-hours jobs, it also makes sense to explore possibilities for cooperative child care arrangements in which parents receive "free" child care in exchange for giving available time to a shared child care enterprise. In addition, parents could be provided with subsidies for caring for their own children in neighborhood parent-child centers alongside paid child care workers, and having those hours count toward work. ${ }^{429}$ This would reduce the isolation of caring for young children, provide parenting support, create and strengthen community bonds, and socialize and educate children. ${ }^{430}$

Provision of child care should also be directly linked to community economic development (CED) initiatives. CED aims to improve the quality of life within distressed neighborhoods by enabling non-profit, nongovernmental entities to develop housing, jobs, or business opportunities for low-income people. ${ }^{431}$ CED's theoretical foundations are largely communitarian, in that CED focuses on empowering geographically bounded communities and remaining accountable to them. Yet, perhaps not surprisingly, child care is rarely seen as part of an overall CED strategy because child care involves human, rather than physical, capital. ${ }^{432}$ At the same time, economic development is stymied if potential workers lack access to child care. This oversight could be remedied if federal and state governments gave developers, business owners, non-profits, community groups, and religious entities technical assistance and economic incentives such as tax credits, loan guarantees, or bonds to build and operate child care facilities in low-income neighborhoods. ${ }^{43}$ Where such approaches have been

428. See Joan Fitzgerald, Caring for Children as Career, The Prospect, July 15, 2002, available at http://www.prospect.org. The program reduced employee turnover and increased the quality of care, as well as parent and teacher satisfaction.

429. Lucie White proposes such a program as an alternative to the unrealistic expectation that all child care can be provided by a professional class of child-care workers. See Lucie White, Quality Child Care for Low-Income Families, in Hard Labor: Women and Work in the Post-Welfare Era 116, 138-39 (Joel F. Handler \& Lucie White eds., 1999).

430. $I d$.

431. See Simon, supra note 297, at 3.

432. See Warner et al., supra note 410 , at 296.

433. See Kaplan, supra note 411. 
tried, the integration of child care with economic development pays for itself, in terms of the "real dollars returned to the government through taxes on family earnings, employment, and the child care industry." ${ }^{, 434}$ By linking child care with economic development, we can publicly value care work, meet community needs, involve community members in providing child care, and boost the likely success of development initiatives. This would not only foster healthy families, a prime concern of communitarians, but could also lead to increased civic participation as families become economically secure and capable of envisioning change.

\section{Spatial Mismatch}

One explanation for high levels of unemployment in minority, lowincome urban neighborhoods is spatial mismatch, which posits that due to residential segregation, inner-city blacks live too far away from the suburbs, where most job creation is taking place. ${ }^{435}$ Spatial mismatch is exacerbated by many factors, such as lack of transportation, inaccessibility of job sites to public transit, excessive commuting times, lack of information in inner-city neighborhoods about suburban job opportunities, and racial discrimination against blacks in hiring. ${ }^{436}$ Welfare reformers are well aware of spatial mismatch and have targeted their efforts at improving transportation between urban residences and suburban jobs. With federal funding, the states have implemented a variety of measures, including reducing rates for public transportation, new bus routes and mini-buses for low density routes, contracts with commuter ride services, and low-interest loans to buy cars. ${ }^{437}$ Yet, these solutions are not serving all who need them, in part because benefits disappear once the working poor leave welfare. ${ }^{438}$ Moreover, although these mobility

434. Warner et al., supra note 410 , at 306.

435. See Keith R. Ihlanfeldt \& David J. Sjoquist, The Spatial Mismatch Hypothesis: A Review of Recent Studies and Their Implications for Welfare Reform, 9 Housing Pol. Debate 849, 849 (1988), available at http:www.innovations.harvard.edu/showdoc.html?id=3022\&p=1 (last visited Mar. 3, 2005). Although spatial mismatch theory has been the subject of controversy, a comprehensive review of the major studies concludes that the theory is valid, particularly with regard to large cities. Id. at 849. See also Steven Raphael \& Michael A. Stoll, Modest Progress: The Narrowing Spatial Mismatch Between Blacks and Jobs in the 1990s (Dec. 2002), available at http://www.brookings.edu/es/urban/publications/ raphaelstoll_spatialmismatch.htm (last visited Mar. 3, 2005) (stating that "in 2000, no group was more physically isolated from jobs than blacks").

436. See Ihlanfeldt \& Sjoquist, supra note 435 , at $878,881$.

437. Nicole Stelle Garnett, The Road From Welfare to Work: Informal Transportation and the Urban Poor, 38 HaRv. J. ON LEGIS. 173 (2001).

438. Id. at 197. 
strategies are less expensive than moving people closer to jobs (desegregation strategy) or moving jobs closer to workers (economic development strategy), they are short-term solutions to long-term problems. ${ }^{439}$ Moving workers to distant low-wage jobs also does little to build stable inner-city communities or to desegregate suburban ones. ${ }^{440}$ Moving people back and forth over long distances and adding hours to the workday also threatens to disrupt various social networks and to stretch the already thin capacity of child care. At best, mobility programs contribute to asset accumulation within poor neighborhoods; yet, given the low wages typically earned in the entry-level jobs service jobs available to welfare recipients, this is unlikely.

A community-based approach to overcoming spatial mismatch would focus on job creation within or near inner-city neighborhoods. As such, it would require states and cities to coordinate their TANF programs with their workforce and economic development programs, which often operate in entirely disconnected spheres. ${ }^{41}$ Although states are permitted to spend TANF funds on economic development initiatives, ${ }^{442}$ few are doing so, given TANF's work-first emphasis. Moreover, experience with governmental economic development programs has shown that luring businesses to relocate within distressed neighborhoods with financial incentives alone is not enough to generate a significant number of jobs for inner-city residents. ${ }^{443}$ Public

439. Ihlanfeldt \& Sjoquist, supra note 435 , at $882-83$.

440. It does, however, potentially open up an avenue for job creation by jitney operators who provide transportation to residents. See Garnett, supra note 437, at 212-17 (arguing for elimination of legal barriers to jitney services).

441. See Connecting Poverty Reduction, Workforce Development, and Economic Development: A Mid-Term Report on the Workforce Development for Poverty Reduction Project 1, 9 National League of CitiES, at http://www.nlc.org/nlc_org/site/files/reports/connecting.pdf. The Report states that “[c]ities and their partners need to think more broadly about workforce development and economic development. They need to be seen as labor market issues that affect the economy of the entire region, and as issues that are influenced by underlying factors such as race, class, and power." Id. at ii. See also Scott Hebert et al., Interim Assessment of the Empowerment Zones and Enterprise Communities (EZ/EC) Program: A Progress Report (United States Department of Housing and Urban Development 2001), available at www.huduser.org/ Publications/pdf/ezec_report.pdf (last visited Mar. 3, 2005).

442. See Pamela Friedman, Increasing Work Opportunities for Low-Income Workers through TANF and Economic Development Programs (Feb. 2002), available at http://www.financeprojectinfo.org/ Publications/increasingworkopportunitiesIN.htm (last visited Mar. 3, 2005).

443. On the federal Empowerment Zone/Enterprise Community program, see generally Hebert et al., supra note 441 (stating that Enterprise Zones have led to some significant job creation, but it is unclear whether or not those jobs would have been created in the absence of the EZ program). On state enterprise zones, see generally Alan H. Peters \& Peter S. Fisher, State Enterprise Zone Programs: Have THEY WORKED? 1 (2002) (exploring whether the programs have not created employment and are not cost effective). 
services that support business growth must also be improved, such as public safety and education. ${ }^{444}$

In addition, welfare programs could capitalize on the long-standing, small-scale entrepreneurial efforts within low-income neighborhoods by funding microenterprise. ${ }^{445}$ In microenterprise programs, entrepreneurs who lack access to traditional forms of capital are offered small loans to establish and maintain their businesses, while also being provided with business training and technical assistance. ${ }^{446}$ Moreover, these programs often have a peer support component, in which a group of four or five individuals hold separate loans, but all of the members of the group provide collateral for the loan. ${ }^{447}$ Although microenterprise is no panacea for poverty, it appeals to many economic development practitioners because it has the potential to create self-sufficiency as part of a broader economic justice movement and to build upon social capital within poor neighborhoods. ${ }^{448}$

444. See Timothy J. Bartik, Solving the Many Problems with Inner City Jobs at 2 (Oct. 2000), at http://www.upjohninst.org/publications/wp/00-66.pdf (last visited Mar. 3, 2005)

445. "A microenterprise in the U.S. is often defined as a sole-proprietorship, partnership or family business that has fewer than five employees, does not generally have access to the commercial banking sector, can initially utilize a loan of less than $\$ 25,000$ to start or expand a business that usually grosses less than \$250,000 per year." Susan R. Jones, Representing the Poor and Homeless: Innovations in Advocacy: Tackling Homelessness Through Economic Self-Sufficiency, 19 St. Louis U. Pub. L. Rev. 385, 389 (2000) [hereinafter Jones, Tackling Homelessness]. Although many states are reluctant politically to support extended training programs, there are no legal barriers to a state funding a microenterprise program with TANF dollars. See Mark Greenberg, Developing Policies to Support Microenterprise in the TANF Structure: A Guide to the Law, Center for Law and Social Policy, 1999, available at http://www.clasp.org/ publications/welfare_policy.htm.

446. Laurie A. Morin, Legal Services Attorneys as Partners in Community Economic Development: Creating Wealth for Poor Communities Through Cooperative Economics, 5 UDC/DCSL L. Rev. 125, 131-32 (2000).

447. See Susan R. Jones, Small Business and Community Economic Development: Transactional Lawyering for Social Change and Economic Justice, 4 Clinical L. Rev. 195, 21 6-17 (1997),

448. See, e.g., Robert E. Suggs, Bringing Small Business Development to Urban Neighborhoods, 30 HARV. C.R.-C.L. L. REV. 487 (1995) (discussing the importance of black business development). Susan Jones points to the results of an Aspen Institute study that

tracked 403 low-income entrepreneurs from 1991 through 1997 and found that $72 \%$ of low-income microenterpreneurs experienced gains in income; $53 \%$ had household income gains large enough to move them out of poverty; microentrepreneurs in the study reduced their reliance on public assistance by $61 \%$; and the business survival rate was $49 \%$, comparable to national statistics for business success.

Jones, Tackling Homelessness, supra note 445, at 390 (2002). But see Louise A. Howells, The Dimensions of Microenterprise: A Critical Look at Microenterprise as a Tool to Alleviate Poverty, 9 J. AfF. HsG. \& Сомm. Dev. L. 161 (2000) (arguing that microenterprise is unlikely to alleviate poverty because of lack of skills, resources, and support within poor communities). 
In addition to creating individually-owned small businesses, welfare policy could promote initiatives to build worker cooperatives, which are businesses that are owned and democratically controlled by the workers. ${ }^{449}$ One of the most prominent worker cooperatives is the Cooperative Home Care Associates, Inc., in the Bronx, New York, a home health care business owned by 300 minority women that is founded on CED principles emphasizing "education and empowerment with a low-income constituency, strategic planning, local job and enterprise creation, regional impact and broader replication, sophisticated finance and business expertise, democratic values, and selective use of public subsidies to build local capacity." ${ }^{450}$ The democratic structure of worker cooperatives allows them to not only create jobs, but also to serve as a platform for political engagement and grassroots activism. ${ }^{451}$ The form has been particularly successful in organizing immigrant day laborers and domestic workers to negotiate collectively with their customers. ${ }^{452}$

In addition to building jobs within the inner-cities, there is more than enough room within a community-based welfare system for concurrently pursuing desegregation strategies that move inner-city residents to suburban areas. $^{453}$ For instance, two major federal mobility efforts, the Gautreaux program and the Moving to Opportunity program (MTO), moved poor, mostly black residents from distressed inner-city neighborhoods to majority-white, middle-class suburban neighborhoods. ${ }^{454}$ Studies of these programs found

449. See Scott L. Cummings, Developing Worker Cooperatives as a Job Creation Strategy for LowIncome Workers, 25 N.Y.U. Rev. L. \& Soc. ChAnge 181, 185 (1999). "Like all cooperative businesses, a worker cooperative adheres to fundamental principles, such as voluntary and nondiscriminatory membership, democratic member control, equitable economic participation by members, and a commitment to ongoing member education." Id. at 185-86.

450. Morin, supra note 446, at 139-40; see also Peter Pitegoff, Shaping Regional Economies to Sustain Quality Work: The Cooperative Health Care Network, in HARD LABOR, supra note 429, at 96-115.

451. Cummings, supra note 256, at 473.

452. Id. at 477 .

453. See Michael Schill, Assessing the Role of Community Development Corporations in Inner City Economic Development, 22 N.Y.U. Rev. L. \& Soc. Change 753, 759 (1996-97) (arguing that although Community Development Corporations have been successful on several measures, we still need other remedies for inner-city poverty); Simon, supra note 297, at 225 ("Unfortunately, there is no need to choose between CED and mobility policy. Neither shows any imminent prospect of massive success that would obviate the need for the other.").

454. For a description and comparison of the two programs, see Pindell, supra note 357, at 413-19. Gatreaux was the result of a court-ordered desegregation plan that was upheld by the Supreme Court. Hills v. Gautreaux, 425 U.S. 284, 305-06 (1976). The Moving to Opportunity program was a demonstration project enacted by Congress and administered by the Department of Housing and Urban Development that attempted to build on the lessons learned from the Gautreaux participants. Housing and Community Development Act of $1992 \S 152$, repealed by P.L. 105-276, Title V, Subtitle C, 550(f), 112 Stat. 2610 
improvements in education, health, and safety among participants, along with less-promising outcomes in terms of employment and receipt of public assistance. ${ }^{455}$ These programs are based, in part, on the theory that poor people who live among the middle-class will have better role models and access to information about jobs. Yet, status differences need to be overcome for there to be meaningful contacts among the affluent and their low-income neighbors. ${ }^{456}$ In other words, conscious efforts need to be made by housing authorities to integrate mobility participants into their new neighborhoods, through neighborhood associations or other community groups, and poor residents need support to ensure that their housing is indistinguishable from that of their neighbors. ${ }^{457}$ Community needs to be fostered; it does not arise on its own, and the value of community should not be forgotten even with desegregation strategies. Although communitarians tend to focus on involuntary societal connections, given the mobility within modern society, they also recognize the need to create community where it is lacking.

\section{Lack of Jobs}

Our social welfare system also requires recognition that in certain areas, and particularly in times of recession, there simply are not enough jobs for all who need them-even if the barrier of spatial mismatch is overcome. ${ }^{458}$ Moreover, many welfare recipients face multiple personal barriers to work, such as mental and physical health problems, drug or alcohol addictions, low educational levels, and the like. Accordingly, relying solely on the market to create jobs is not enough. Some jurisdictions have acknowledged as much and have used their TANF funds to create wage-paying jobs for employment in positions that meet community needs, particularly with governmental agencies

(1998).

455. See generally Mark Shroder, Moving to Opportunity: An Experiment in Socialand Geographic Mobility, 5 Cityscape: A J. of Pol'y Dev. \& Res. 57 (2001) (summarizing results of major studies of MTO), available at http://www.huduser.org/periodicals/cityscpe/vol5num2/shroder.pdf(last visited Mar. 3, 2005).

456. Rachel Garshick Kleit, The Role of Neighborhood Social Networks in Scattered-Site Public Housing Residents' Search for Jobs, 12 Hous. PoL'y DeBATE 541, 562-63 (2001), available at http:// www.fanniemaefoundation.org/programs/hpd/pdf/HPD_1203_kliet.pdf (last visited Mar. 3, 2005).

457. Id.

458. See Philip Harvey, Combating Joblessness: An Analysis of the Principal Strategies that Have Influenced the Development of American Employment and Social Welfare Law in the in the 20th Century, 21 Berkeley J. EMP. \& LAB. L. 677, 709 (2000) (concluding that most unemployment is caused by a lack of jobs, not individual behavior or insufficient job skills). 
and non-profits. ${ }^{459}$ Community service employment has the advantages of building self-esteem, improving income by making the worker eligible for the EITC, keeping workers within their communities, and providing needed services to distressed neighborhoods. ${ }^{460}$ Significantly, such programs acknowledge the larger community's obligation to provide support for those who want to work.

\section{Barriers to Self-Sufficiency}

Just because welfare recipients are moved into the workforce does not mean that they are self-sufficient. To the contrary, 3.5 million full-time workers in America remain below the poverty line. ${ }^{461}$ Nearly half of poor adults work at least part-time. ${ }^{462}$ Moreover, the number of families struggling to make ends meet is even more extreme than the poverty line indicates, because the poverty line is a woefully inadequate measure of the income required to meet basic needs. ${ }^{463}$ As a result, economists have studied what it would cost for a family to meet basic needs without government benefits or other subsidies or supports. ${ }^{464}$ These self-sufficiency standards, which vary by geographic location, take into account family size and ages, as well as the impact of tax policies. A study by the Economic Policy Institute shows that, on average, a two-parent, two-child family needs to earn from $\$ 27,005$ a year to $\$ 52,114$, depending on the community, with the national self-sufficiency

459. See Steve Savner \& Mark Greenberg, Community Service Employment: A New Opportunity Under TANF, Center for Law and Social Policy, 1997, at 1. Publicly-paid wages are superior to programs that pay welfare benefits to recipients who participate in community-based internships because the former allow for greater income and afford participants the same rights and status as other workers. Id.

460. Id. Moreover, programs in which welfare recipients receive their welfare benefits in exchange for work have been uniformly unsuccessful in increasing earnings or leading to full-time employment. See Pamela Friedman, Community Work Experience and Publicly Funded Jobs, Helping the Hard to Serve Meet Work Requirements (July 1999), available at http://www.financeprojectinfo.org/ Publications/communityissuenote.htm (last visited Mar. 3, 2005). For a full description and assessment of community work programs, see David T. Ellwood \& Elisabeth D. Welty, Public Service Employment and Mandatory Work: A Policy Whose Time Has Come and Gone and Come Again (Mar. 6, 1999), at www.jcpr.org/wpfiles/ellwood-welty.pdf (last visited Mar. 3, 2005).

461. U.S. Department of Labor, Bureau of Labor Statistics, A Profile of the Working Poor, 2001, Report 968 (June 2003). This amounts to 6.8 million people. Id.

462. ICELAND, supra note 108 , at 3.

463. For a discussion of how the poverty line is established and its inadequacies, see ICELAND, supra note 108 , at $20-37$.

464. See generally Diana Pearce, Self-Sufficiency Standard: ANew Tool for Evaluating Anti-Poverty Policy (Sept. 2001), at http://www.afsc.org/pwork/0109/010907.htm (last visited Mar. 3, 2005); Heather Boushey et al., ECOn. Policy Inst., Hardships in America: The Real Story of Working Families (2001), summary available at $\mathrm{http}: / / \mathrm{www}$. epinet.org/content.cfm/books_hardships (last visited Mar. 3, 2005). 
median at $\$ 33,511$, which is about twice the poverty line. ${ }^{465}$ Accordingly, we need to ensure that people who work earn enough money to be economically independent.

Interestingly, this is one point on which many liberals and communitarians can agree. For a liberal, self-sufficiency is needed to provide individuals with dignity and to foster personal autonomy. A communitarian such as Michael Walzer might argue that, as a nation, we must live up to our shared understanding that full-time workers should not live in poverty. Indeed, public opinion polls back up this assertion and the "shared understandings" touchstone thus works, in this instance, to benefit the working poor. ${ }^{466}$ Michael Sandel might argue that self-sufficiency is essential to further civic republican values, because it allows people to focus and debate on the common good without worrying solely about basic subsistence. There are three major routes for enhancing self-sufficiency. First, workers in the low-wage, low-skill workforce should earn enough money to meet basic needs. Second, there should be a concerted effort to move workers out of lowwage jobs into jobs with greater earning potential by increasing their job training and educational opportunities. Third, low-income families need services and support to begin accumulating assets. Within each of these options, there are community-based strategies that could be implemented to augment existing social bonds and to foster new ones.

\section{Raising Income}

There are several ways in which to raise the income of our low-skill, lowwage workers. For instance, the Earned Income Tax Credit, which is a refund against tax liability, has greatly enhanced the income of millions of low-wage families who have earned income under $\$ 33,692$, (or $\$ 34,692$ for married filers). ${ }^{467}$ The amount of the credit depends on the earner's income, the

465. Boushey, supra note 464, at 1. "For example, using [Diana] Pearce's self-sufficiency calculations in Texas, in 1997 a single parent with an infant and a preschool-age child would have needed to earn monthly wages of $\$ 2,385.99$ ( $\$ 13.56$ hourly) in Austin, compared to monthly wages totaling $\$ 1,685.51$ (\$9.58 hourly) in Wichita Falls." Patricia Cole \& Sarah M. Buel, Safety and Financial Security for Battered Women: Necessary Steps for Transitioning from Welfare to Work, 7 GEO. J. ON POVERTY L. \& POL'Y 307, 328 (2000) (summarizing purpose and benefits of the self-sufficiency standard).

466. See William Quigley, Full-Time Workers Should Not Be Poor: The Living Wage Movement, 70 Miss. L.J. 889, 895 (2001) ("An April, 2000 survey found that 94\% of the one thousand adults questioned agreed with the statement that "as a country, we should make sure that people who work fulltime should be able to earn enough to keep their families out of poverty.").

467. Internal Revenue Service, Publication 596, The Earned Income Tax Credit (2003). 
number of dependent children in the family, and the claimant's marital status. ${ }^{468}$ The maximum amount of the credit is $\$ 4,204$ for a family with two or more children, or $\$ 382$ for an adult with no children. ${ }^{469}$ Over 20 million people claimed the EITC in 2000, and the federal government now spends more on the EITC than it does on TANF, making it the largest federal antipoverty program. ${ }^{470}$ Although the EITC has lifted many families above the poverty line (although not necessarily to a level of self-sufficiency), ${ }^{471}$ the process of claiming the EITC is excessively complicated, claimants are audited at a much higher rate than middle- and upper-income earners, and the low-wage population is preyed upon by tax preparers who take a hefty share of the tax credit. So, these flaws in the program need to be corrected. In addition, while the EITC is a strong moral expression of the value of work performed by low-wage earners, the entire cost of the EITC is borne by taxpayers.

Employers should also play a role in increasing income levels of their workers, an approach consistent with the communitarian emphasis on reciprocity. Accordingly, a raise in the minimum wage is long overdue. For instance, the poverty line for a family of three is $\$ 14,824,{ }^{472}$ but a singlemother with two children who makes the minimum wage earns only $\$ 10,712$. The minimum wage is currently $\$ 5.15$ an hour, a value that is thirty percent below the wage's peak in 1968, as adjusted for inflation, and nineteen percent below its value in $1979 .{ }^{473}$ A full-time worker working fifty-two weeks a year at the minimum wage earns only $\$ 10,712$ per year. Moreover, a 1999 study showed that if the wage was raised by $\$ 1.50,11.9$ million workers would be affected; almost seventy percent of the workers would be over twenty; and over forty-five percent of the workers would be full-time workers. ${ }^{474}$ Even with a higher minimum wage, however, the self-sufficiency standards

468. See Dan Selzer, Note, Attacks on a Tax: An Alternative to the Earned Income Tax Credit to Remedy the Unfairness in the Payroll Tax System, 77 S. CAL. L. REv. 187, 196-97 (2003) (providing a history and description of the EITC).

469. IRS Outlines Income Tax Eligibility for the 2003 Tax Year, available at http://www.irs.gov/ newsroom/article/0,,id=1 19793,00.html (last visited Mar. 3, 2005).

470. See Leslie Book, The IRS' EITC Compliance Regime: Taxpayers Caught in the Net, 81 Or. L. REv. 351, 363-64 (2002).

471. Id. at 367 .

472. United States Census Bureau, Poverty 2003, at http://www.census.gov/hhes/poverty/threshld/ thresh03.html (last visited Mar. 3, 2005)

473. See Edith Rasell et al., Step Up, Not Out: The Case for Raising the Federal Minimum Wage for Workers in Every State, Economic Policy Institute Issue Brief \#149, (Economic Policy Institute), Feb. 2001.

474. Quigley, supra note 466, at 917. 
demonstrate that different communities impose different costs on their residents. Although a variable minimum wage is probably not desirable for the economic disincentives it would create, self-sufficiency standards can assist jurisdictions to identify the subsidy levels needed for services such as child care or health coverage; target jobs that pay sufficiency-level wages and train welfare recipients for those jobs; and ensure that welfare recipients are not cut-off from needed services and subsidies as they transition off of welfare. ${ }^{475}$

Living wage laws are another way for a community to value its workers and to tailor wage levels to local costs and economic conditions. Currently, eighty-three cities and counties have living wage laws, which generally set a minimum wage for employees of businesses that contract with or receive subsidies from government. ${ }^{476}$ Although the economic impact of living wage laws is deeply contested, they have not caused significant economic damage to any jurisdiction that has implemented them, and they have brought a small number of workers out of poverty. Given the virtual stalemate in the economic arguments surrounding living wage statutes, the balance is tipped by the moral and symbolic value of these statutes as an expression of community norms, along with the personal dignity they afford to workers. Significantly, living wage campaigns have been spearheaded by grassroots contingents of low-income workers demanding economic justice, and can become platforms for organizing around other issues facing distressed communities. ${ }^{477}$

\section{Educational Opportunity}

Improving access to higher education is a proven method of achieving higher earnings and upward social mobility. ${ }^{478}$ Yet, the work-first mandate of TANF limits post-secondary educational opportunities for welfare recipients by making education count as a "work activity" in only narrow

475. Pearce, supra note 464.

476. See Rachel Harvey, Labor Law: Challenges to the Living Wage Movement: Obstacles in a Path to Economic Justice, 14 U. FLA. J.L. \& PUB. PoL'Y 229 (2003) (summarizing the history and scope of the living wage movement, as well as the arguments for and against the living wage movement). See also Quigley, supra note 466, at 889 n.2 (listing resources about the living wage movement).

477. See Cummings, Progressive Politics, supra note 256, at 469-72.

478. See Karin Martinson \& Julie Strawn, Built to Last: Why Skills Matter for Long-Run Success in Welfare Reform 12 (Center for Law and Social Policy, Workforce Development Series Brief No. 1, 2003). 
circumstances. ${ }^{479}$ As a result, most states have focused on moving welfare recipients into low-skill jobs as quickly as possible. ${ }^{400}$ Post-TANF, the percentage of welfare recipients enrolled in college dropped by half, as thousands of women had to drop out of college and take low-wage jobs. ${ }^{481}$ As a result, these women are denied the increased earnings of six to twelve percent that accompany each year of postsecondary education. ${ }^{482}$ A bachelor's degree alone increases median earnings by seventy-one percent. ${ }^{483}$ Not only are earnings higher with each increased level of education, but women with college experience spend more time employed. ${ }^{484}$ Although the short-term costs of education are higher than moving women into low-wage jobs, in the long-term women with college educations are far less likely to become dependent on public benefits. ${ }^{485}$

Increased education would also correct the current labor market imbalance in which there is an oversupply of low-skilled workers and an undersupply of educated workers. ${ }^{486}$ Accordingly, it is imperative that our welfare system allow education to count as work and to support mothers who pursue upper-level degrees. ${ }^{487}$ In this effort, the existing infrastructure of community colleges can be a powerful tool, and, in some states, community colleges are already extensively involved in welfare delivery as part of the welfare to work program. ${ }^{488}$ They train students in fields needed within the local economies and they often combine classroom work with internship and other training opportunities. ${ }^{489}$ Community colleges are particularly potent partners in linking welfare to education because of their community-based mission, experience in serving diverse student bodies, wide range of course

479. See Rebekah J. Smith, Luisa S. Deprez \& Sandra S. Butler, The Miseducation of Welfare Reform: Denying the Promise of Postsecondary Education, 55 ME. L. Rev. 211, 216 (2002).

480. See id. at 216.

481. See id.

482. See id. at 219 .

483. See id. at 214.

484. See id. at 221

485. See id. at 222.

486. See Center for Women's Policy Studies, From Poverty to Self-Sufficiency: The Role of Postsecondary Education in Welfare Reform 5 (2002).

487. For specific policy recommendations, see Susan Golonka \& Lisa Matus-Grossman, Manpower Demonstration Research Corporation, Opening Doors: Expanding Educational Opportunity for LowIncome Workers (May 2001).

488. See Marie Cohen, Post-secondary Education under Welfare Reform (Welfare Information Network), Issue NOTES vol. 2, no. 8, 1998.

489. Id. 
offerings, linkages with employers, and low tuition and open admissions policies. ${ }^{490}$

\section{Asset Development}

Raising the income levels of welfare recipients and the working poor is unlikely to lead to self-sufficiency in the absence of opportunities for these individuals to accumulate assets. Asset development has long been a centerpiece of public policies that benefit the middle-class, through historic programs such as the Homestead Act of 1962 and the GI Bill, and current programs such as the federal mortgage interest deduction and tax-favored retirement accounts. ${ }^{491}$ Yet, the poor have not benefitted from these wealth building programs. Since 1991, when Michael Sherraden proposed strategies for asset accumulation among the working poor, ${ }^{492}$ anti-poverty advocates have expanded their focus to include not only enhancing income, but also accumulating income. The major policy vehicle for asset accumulation by the poor is Individual Development Accounts (IDA). ${ }^{493}$ With IDAs, public and private funders match savings deposited by the working poor on a $1: 1$ or $2: 1$ ratio. Usually, IDA programs provide financial literacy training to participants, ${ }^{494}$ and funds are restricted to certain purposes, such as homeownership, post-secondary education, and small business capitalization. ${ }^{495}$ TANF allows states to use their federal funds toward IDA programs, and thirty states have done so. ${ }^{496}$ Although there are 500 IDA programs nationwide, they only enroll 10,000 individuals. ${ }^{497}$

490. See Golonka \& Matus-Grossman, supra note 487, at 14-24.

491. See J. Larry Brown \& Larry W. Beeferman, From New Deal to New Opportunity, 12 THE American Prospect, Feb. 12, 2001 (describing theoretical debates over asset development); Creola Johnson, Welfare Reform and Asset Accumulation: First We Need a Bed and a Car, 2000 WIs. L. Rev. 1221, 1227-28 (2000); Colleen Dailey \& Ray Boshara, Achieving Economic Self-Sufficiency Through Asset Building: Opportunities for Low-Income Workers, Corporation for Enterprise Development, May 2000.

492. Michael Sherraden, Assets and the Poor: A New American Welfare Policy (1991).

493. There are other ideas for assisting the poor in accumulating assets. See, e.g., BRUCE ACKERM AN \& Anne Alstott, The Stakeholder Society 4 (arguing that every U.S. citizen with a high school diploma be given $\$ 80,000$ on their twenty-first birthday).

494. Twenty percent of Americans do not have a checking or savings account. Dailey \& Boshara, supra note 491, at 4 .

495. Creola Johnson argues that participants should be allowed to use IDA funds for more basic needs, such as furniture or a car. See Johnson, supra note 491, at 1225.

496. Center for Source Development, Asset Building: Individual Development Accounts (2003), available at gwbweb.wustl.edu/csd/Areas_Work/Asset_building/IDAs (summarizing status of IDA programs nationwide).

497. Id. 
Yet, they are promising programs; data from the first national demonstration project shows that low-income people "can and do save when given incentives and institutional support." ${ }^{\text {"498 }}$ Proponents assert that IDAs create greater household stability, improve self-esteem, provide money management experience, and allow for long-term planning and social mobility. In addition, asset accumulation is expected to foster increased community involvement, social connectedness, and civic participation. ${ }^{499}$ Given the small-scale of these programs, they obviously need to be expanded dramatically to have any significant impact on anti-poverty efforts. ${ }^{500}$ At the same time, it may be possible to expand the concept of IDAs to include groups, as well as individuals, as the locus of savings. ${ }^{501}$ For instance, IDAs could be structured on a microcredit model, in which the "basic unit is a group of neighbors that administers loans to members, uses ties of mutual trust and obligation to enforce repayment, passes on information and expertise, and provides mutual aid. ${ }^{502}$ Both individually-based and group-based IDAs have the potential to build vibrant communities, as members are financially able to articulate long-term plans and goals and become stakeholders in the futures of their neighborhoods.

\section{Welfare and Morals}

TANF endorses a distinct moral vision that assumes welfare recipients are morally deficient and need financial incentives to conform their behavior to middle-class norms. As such, TANF is far from value-neutral; it reflects widely-shared values within American society. For instance, TANF prefers work over caretaking and nuclear families over other family groupings. In that sense, it is strongly communitarian. However, TANF raises several tensions within communitarian theory. What happens when the nation's moral vision threatens to weaken and undermine certain communities? Whose moral vision predominates? Who gets a say in determining the moral vision? While communitarians seem to assume that moral values enhance community, TANF

498. See Dailey \& Boshara, supra note 491, at 6 . An IDA demonstration project revealed that very low income accountholders (at or below fifty percent of the federal poverty line) saved eight percent of annual income. Participants who were former welfare recipients saved $\$ 6$ more on average per month than non-welfare recipients. Id. at 6 .

499. See Dailey \& Boshara, supra note 491, at 1-2.

500. The Assets for Independence Act of 1998 established a five year, national IDA demonstration expected to reach 30,000 to 40,000 working poor by 2003. See 42 U.S.C. $§ 604$ (2000).

501. See Lin, supra note 309, at 265.

502. Id. 
demonstrates that this is not always the case. Moreover, TANF focuses its moral gaze solely on the most marginalized members of society. "Because poor families are subject to public oversight, they are subject to public condemnation on moral grounds for behaviors, such as nonmarital cohabitation and childbearing, that no longer provoke sanction or comment among the rest of the population." ${ }^{503}$

One way to resolve these contradictions is to focus on community building, because positive behavioral and moral outcomes are likely to result. If welfare recipients have economic security, many of TANF's behavioral modification incentives will no longer be necessary to secure the desired outcomes..$^{54}$ For instance, one of the purposes of TANF is to encourage "formation and maintenance of two-parent families." ${ }^{105}$ President Bush has proposed pumping $\$ 1.5$ billion into marriage promotion activities as an antipoverty tool. ${ }^{506}$ These proposals are founded on data that show that singleparent families have a much higher poverty rate (twenty-six percent) than twoparent biological families (five percent), and that sixty-nine percent of children of single-mothers who never marry are poor. ${ }^{507}$ This does not mean, however, that marriage will cure poverty, because if two poor people marry, they are still poor..$^{508}$

Rather, poverty is both a cause and an effect of single parenthood. ${ }^{509}$ Thus, if currently jobless African-American males obtained well-paying jobs, it is likely that the marriage rate in inner-city communities would increase far more than it would with the counseling programs and other horatory methods being packaged as part of marriage promotion. ${ }^{510}$ Of course, disincentives to marriage should be removed within the welfare and tax systems, but marriage

503. Ann Laquer Estin, Marriage and Belonging, 100 Мich. L. Rev. 1690, 1706 (2002).

504. Martha McCluskey aptly criticizes communitarians for focusing on reforming the morals of welfare recipients rather than focusing on economic justice. Martha T. McCluskey, Efficiency and Social Citizenship: Challenging the Neoliberal Attack on the Welfare State, 78 IND. L.J. 783, 822-32 (2003).

505. 42 U.S.C. $\S 601(a)(4)(2000)$.

506. Robert Pear \& David D. Kirkpatrick, Bush Plans \$1.5 Billion Drivefor Promotion of Marriage, N.Y. Times, Jan. 14, 2004, at A1.

507. See Mary Parke, Center for Law and Social Policy, Are Married Parents Really Better for Children? What Research Says About the Effects of Family Structure and Child Well-Being (Brief No. 3, 2003).

508. See Michael Selmi \& Naomi Cahn, Caretaking and the Contradictions of Contemporary Policy, 55 Me. L. Rev. 289, 295 (2002). Moreover, given the high rates of domestic violence associated with poverty, marriage promotion cannot work without focusing on abuse prevention and mental health supports. See id. at 296.

509. See Parke, supra note 507, at 6.

510. See id.; Selmi \& Cahn, supra note 508, at 295-96. 
promotion programs may penalize children of single-parents and are misdirected at the real causes of low marriage rates. As Michael Selmi and Naomi Cahn have pointed out, such marriage promotion initiatives permit the government to evade responsibility for alleviating poverty. They "change the focus from the workplace to the family, and from systemic problems faced by women to individual blame." 511 They privatize the burden for alleviating poverty, rather than calling for collective responsibility. As a practical matter, marriage does not always lead to superior outcomes. It can enforce women's dependence on men, and threaten women's financial well-being in the event of divorce ${ }^{512}$ - which occurs in fifty percent of all marriages. ${ }^{513}$ Moreover, while children do best in low-conflict families with two biological parents, step-families have no greater child outcomes than single-parent families. As a result, "[e]ducation, training, and jobs provide more stable protection against poverty than does the simple fact of marriage." ${ }^{514}$

This suggests that the moral vision with the least risk of marginalizing the poor and the most likelihood of reducing poverty is one that is committed to obtaining economic justice for the poor. It is a moral vision that most Americans agree with, and it is one that is most likely to improve civic participation and re-energize the political process. Testing welfare recipients for drugs and capping their welfare benefits when new children are born achieves nothing but moral censure. A moral voice that fails to impact outcomes is like shouting into the wind. Surely, we can do better.

\section{Conclusion}

Michael Walzer describes communitarianism as a recurrent critique within liberalism. While communitarianism is unlikely to ever replace liberalism, or even to radically transform our political landscape, Walzer views it as a corrective to the sense of loss in an increasingly mobile and unsettled society. For the poor, however, who are significantly less mobile and more unsettled than the rest of society, communitarianism offers a corrective for a different failing within liberalism. The American meritocracy myth, postulating that anyone can get ahead based on individual merit in a land of endless opportunity, results from, and is constantly reinforced by, our liberal tradition. Liberalism thus provides the vocabulary by which the poor 
are penalized. By contrast, because communitarianism focuses on the involuntary ties that bind us, it offers a way out of this trap. It forces us to examine communities, both for the good they offer and the harms they exact on their members. It requires that we look to the structural social and economic forces that shape communities and define their members. In focusing on the common good, it suggests a national communal obligation to alleviate hardships within distressed communities.

Yet, communitarianism offers perils as well. It can be unduly moralistic, majoritarian, and authoritarian in attempting to articulate visions of the good life without providing avenues for resolving dissent and discord about what constitutes the good. Here, liberalism offers the corrective through its values of individual dignity and human rights. The poor exercise autonomy within a very constrained sphere of opportunity and are subject to governmental intrusions into their personal privacy. If anything, they need increased autonomy; not less. Moreover, the few rights that the poor do possess-such as constitutional rights to fair and equal treatment in the receipt of public benefits, protection against unlawful searches and seizures, and access to the courts - help to maintain community, rather than to threaten it. In learning about and exercising these and other statutory rights, the poor can move even beyond Sandel's genteel notions of civic republicanism and build community through coalition-building and grassroots organizing that makes demands on the larger community for economic justice. The poor need both community and individual rights simply to survive, and they certainly need both to flourish. 